\title{
AVALIAÇÃO DA TOLERÂNCIA DE CANA-DE-AÇÚCAR (Saccharum spp.) A METAIS: EXPRESSÃO DOS GENES DE METALOTIONEÍNA
}

\author{
MARIA LORENA SERENO
}

\begin{abstract}
Dissertação apresentada à Escola Superior de Agricultura "Luiz de Queiroz", Universidade de São Paulo, para obtenção do título de Mestre em Agronomia, Área de Concentração: Genética e Melhoramento de Plantas.
\end{abstract}

P I R A C I C A B A

Estado de São Paulo - Brasil

Agosto - 2004 


\title{
AVALIAÇÃO DA TOLERÂNCIA DE CANA-DE-AÇÚCAR (Saccharum spp.) A METAIS: EXPRESSÃO DOS GENES DE METALOTIONEÍNA
}

\author{
MARIA LORENA SERENO
}

Licenciada em Genética

Orientador: Prof. Dr. ANTONIO VARGAS DE OLIVEIRA FIGUEIRA

\begin{abstract}
Dissertação apresentada à Escola Superior de Agricultura "Luiz de Queiroz", Universidade de São Paulo, para obtenção do título de Mestre em Agronomia, Área de Concentração: Genética e Melhoramento de Plantas.
\end{abstract}

P I R A C I C A B A

Estado de São Paulo - Brasil

Agosto - 2004 


\section{Dados Internacionais de Catalogação na Publicação (CIP) DIVISÃO DE BIBLIOTECA E DOCUMENTAÇÃO - ESALQ/USP}

\section{Sereno, Maria Lorena}

Avaliação da tolerância de cana-de-açúcar (Saccharum spp) a metais: expressão

dos genes de metalotioneína / Maria Lorena Sereno. - - Piracicaba, 2004.

94 p. : il.

Dissertação (mestrado) - - Escola Superior de Agricultura Luiz de Queiroz, 2004.

Bibliografia.

1. Cana-de-açúcar 2. Contaminação química 3. Descontaminação 4. Expressão gênic 5. Metal pesado 6. Proteínas de plantas I. Título

CDD 633.61 
Aos meus pais Nidia e Novo, e a minha irmã Lupe pela força, amor e apoio incondicionais.

\section{OFEREÇO}

Ao Alfredo por ser o meu amor e o meu melhor amigo.

\section{DEDICO}




\section{AGRADECIMENTOS}

Ao Prof. Dr. Antonio Figueira pela orientação, a paciência e a amizade;

À Escola Superior de Agricultura "Luiz de Queiroz", pela oportunidade de realizar o curso de mestrado;

Ao CNPq pela bolsa de estudo de mestrado concedida;

À COPERSUCAR pelo material vegetal e o apoio permanente;

Ao Prof. Dr. Ricardo Ferraz de Oliveira por permitir a realização dos experimentos na casa de vegetação do "Laboratório de Plantas Cultivadas sob Condições de Estresse" da ESALQ/USP;

Ao Prof. Dr. Virgílio Franco do Nascimento, da Divisão de Desenvolvimento de Métodos e Técnicas Analíticas e Nucleares, do CENA/USP, pela ajuda na detecção de metais nas plantas de cana;

Aos Técnicos de laboratório: Raquel Orsi, Wlamir Godoy e Eduardo Fonseca, pela tão importante ajuda oferecida;

Ao amigo Raul pelo inestimável apoio e sugestões durante a realização deste trabalho;

Aos amigos do laboratório de Melhoramento de Plantas: Tercilio, Thiago, Déborah, Vagner, César, Gildemberg, Silvana, Rogério, Jony, Paulo Albuquerque, Paulo Ricardo, Silvio, Felipe, Janaína, Danielle, Aline, Mariana, pelo apoio e amizade constantes; 
Á aluna Érica Jorge do Departamento de Zootecnia pela valiosa ajuda oferecida com o analisador de imagens;

Aos amigos de sempre, Noelia, Rolfi e Analia por todos esses anos e os que virão sem importar o tempo e as distancias;

Aos amigos Margarete, Mariana Daher, Esteban, Luciana, Dany, Alexander, Alejandro, Elizabeth, Henrique, e Carlos, por todos os momentos compartilhados e por fazerem a minha vida em Brasil mais bonita e agradável do que já era;

Aos professores, amigos, colegas e funcionários do Depto. de Genética e Melhoramento de Plantas pela enriquecedora contribuição na minha formação e na minha vida pessoal;

À Raquel Orsi (especialmente), por ter-me dado o melhor presente que já recebi na minha vida: o "Chico". E ao meu cão Chico por me ensinar que brincar um pouco todos os dias faz bem e é necessário;

A Deus, por não desistir de mim;

E a todos os que possa estar esquecendo porque não se chega a lugar algum sozinho, OBRIGADA 


\section{SUMÁRIO}

Página

ABREVIATURAS E SÍMBOLOS ............................................................. viii

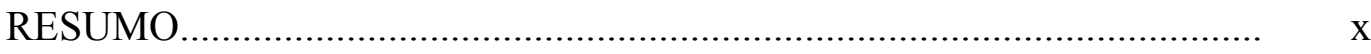

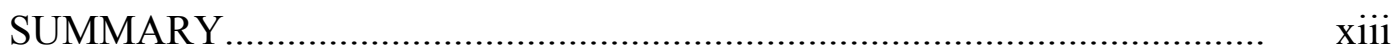

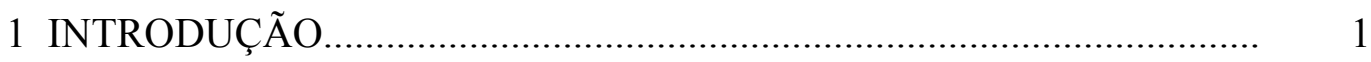

2 REVISÃO BIBLIOGRÁFICA............................................................... 3

2.1 Contaminação ambiental....................................................................

2.2 Tecnologia e métodos para descontaminação.............................................. 4

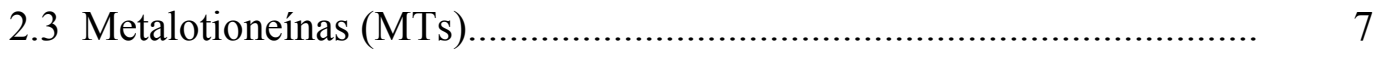

2.3.1 MTs: Classificação............................................................................ 9

2.3.2 MTs: Genes e expressão........................................................................ 11

2.3.3 Possíveis funções associadas às MTs....................................................... 13

3 MATERIAL E MÉTODOS..................................................................... 17

3.1 Material Vegetal................................................................................. 17

3.2 Cultivo em hidroponia......................................................................... 17

3.3 Experimento com metais pesados........................................................... 18

3.3.1 Determinação de metais pesados nos tecidos de cana-de-açúcar.......... 19

3.4 Escolha de clones para serem utilizados como sonda.............................. 20

3.4.1 Purificação de clones EST para confecção de sondas............................ 21

3.5 Extração de DNA de cana-de-açúcar......................................................... 22

3.5.1 Análise de Southern........................................................................... 23

3.6 Extração de RNA total......................................................................... 25 
3.6.1 Análise de expressão por northern blot............................................. 27

3.7 Análises estatísticas......................................................................... 28

4 RESULTADOS E DISCUSSÃO........................................................ 29

4.1 Cultivo de plântulas de cana-de-acucar em concentrações crescentes de $\mathrm{Cu}$ e $\mathrm{Cd}$........................................................................................ 29

4.1.1 Efeito do cobre no crescimento e teor de metal no tecido.................. 29

4.1.2 Efeito do cádmio no crescimento e teor de metal no tecido................. 43

4.2 Purificação de clones EST para confecção de sondas............................. 57

4.3 Análise por Southern blot............................................................... 58

4.4 Análise de expressão por northern blot................................................. 66

5 CONCLUSÕES............................................................................ 80

REFERENCIAS BIBLIOGRÁFICA................................................... 82 


\section{ABREVIATURAS E SÍMBOLOS}

BLAST $=$ Basic Local Alignment Search Tool

CanMT = gene tipo metalotioneína de Cicer arietinum

$\mathrm{CAT}=$ catalase

cDNA $=$ DNA complementar

$\mathrm{cpm}=$ contagem por minuto

$\mathrm{CTAB}=$ Brometo de hexadiltrimetilamonio

$\mathrm{DEPC}=$ dietilpirocarbonato

DNA $=$ Ácido desoxirribonucléico

dNTPs $=\mathrm{N}$-desoxinucleótideo trifosfato

EDTA $=$ Ácido etilenodiaminotetracético

EDXRF $=$ Fluorescência de Raios X por Dispersão de Energia

EST $=$ Etiquetas de Seqüências Expressas

G14 = gene tipo metalotioneína III de Ipomea batatas

$\mathrm{GR}=$ glutationa redutase

HtMT = gene tipo metalotioneína de Heliantus tuberosus

LEMT = gene tipo metalotioneína de Lycopersicum esculentum

$\mu \mathrm{g}=$ micrograma

$\mu \mathrm{J}=$ microjoule

$\mu \mathrm{M}=$ micromolar

$\mathrm{mM}=$ milimolar

MOPS = Ácido 3-[N-Morfolino] propano sulfônico

MilliQ = Água destilada ultra purificada 
mRNA = Ácido ribonucléico mensageiro

MT $=$ Metalotioneína

$\mathrm{NCBI}=$ Centro Nacional de Informação Biotecnológica

$\mathrm{ng}=$ nanograma

PCR $=$ Reação em Cadeia da Polimerase

Primer $=$ iniciador

$\mathrm{PVP}=$ Polivinilpilorridona

$5,8 \mathrm{~S}=$ RNA ribossômico $5,8 \mathrm{~S}$

$18 \mathrm{~S}=$ RNA ribossômico $18 \mathrm{~S}$

$28 \mathrm{~S}=\mathrm{RNA}$ ribossômico $28 \mathrm{~S}$

$\mathrm{SAGE}=$ Serial analysis of gene expression

$\mathrm{SSC}=$ Solução salina de citrato de sódio

SDS $=$ Dodecil sulfato sódico

SOD $=$ superóxido dismutase

SUCEST $=$ Projeto transcriptoma da cana-de-açúcar

$\mathrm{t}=$ tonelada

TAE $=$ Tris-ácido acético-EDTA

$\mathrm{TBE}=$ Tris-borato-EDTA

wali-1 = gene tipo metalotioneína I de trigo

Y459 = gene tipo metalotioneína II de Ipomea batatas 


\section{AVALIAÇÃO DA TOLERÂNCIA DE CANA-DE-AÇÚCAR (Saccharum spp.) A METAIS: EXPRESSÃO DOS GENES DE METALOTIONEÍNA}

Autora: MARIA LORENA SERENO

Orientador: Prof. Dr. ANTONIO VARGAS DE OLIVEIRA FIGUEIRA

\section{RESUMO}

Os metais pesados são elementos químicos com alta densidade $\left(>5{\mathrm{~g} . \mathrm{cm}^{-3}}^{-3}\right.$, presentes naturalmente na crosta terrestre, e o aumento das atividades antropogênicas vêm acelerando a liberação destes elementos nos ecossistemas. Tais elementos podem ser extremamente tóxicos (ex. mercúrio, chumbo, cádmio) ou tóxicos quando em concentrações elevadas (zinco e cobre). A fitorremediação é uma técnica de descontaminação que utiliza as plantas para remover poluentes do ambiente ou transformá-los em formas menos perigosas para os seres vivos, sendo que o impacto ambiental e custos de implementação são muito inferiores àqueles alcançados pelos métodos físico-químicos. Uma cultura para ser utilizada com sucesso na recuperação de áreas contaminadas, deve ser eficiente na acumulação de metais, produzir grandes quantidades de biomassa e ser capaz de se adaptar as condições do ambiente contaminado. A cana-de-açúcar apresenta características fisiológicas, que a tornaram 
uma das culturas mais importantes e difundidas nas regiões tropicais, com alta produtividade de biomassa e rusticidade, possuidora de genes que codificam peptídeos quelantes de metais, já identificados no projeto genoma da cana-de-açúcar (SUCEST).

Neste trabalho foi estudada a expressão gênica de metalotioneínas em plântulas de canade-açúcar. As plântulas foram cultivadas em hidroponia contendo níveis elevados de $\mathrm{Cu}^{+2}(50,100,250$ e $500 \mu \mathrm{M})$ e $\mathrm{Cd}^{+2}(100,250$ e $500 \mu \mathrm{M})$. A concentração do metal foi determinada nos tecidos de raiz e partes aéreas de plantas coletadas após 11 e 33 dias de tratamento. As maiores doses de $\mathrm{Cu}(250$ e $500 \mu \mathrm{M})$ foram letais para as plantas após 11 dias de cultivo, entretanto o efeito das menores dosagens no crescimento foi comparável ao controle aos 33 dias de tratamento. As plantas foram capazes de acumular quantidades significativas de cobre e cádmio, principalmente nas raízes. Todas as dosagens de cádmio limitaram significativamente o crescimento, mas não o impediram. Extratos de RNA total foram analisados para a expressão dos genes de metalotioneína dos tipos I, II e III mediante Northern blot. Os resultados mostraram que houve expressão dos genes para metalotioneínas dos três tipos constitutivamente, sendo mais elevada para MT I e MT II, tanto em folhas como em raízes de cana de açúcar. A expressão de MT I foi maior nas raízes que nas folhas. Já os genes MT II e MT III foram mais expressos em folhas que em raízes. Os genes de metalotioneínas de cana-deaçúcar são pouco afetados ou não são modulados por Cobre. Em relação ao $\mathrm{Cd}$, ocorre um acúmulo de transcritos de MT nas raízes aos 11 dias levemente proporcional à concentração do metal, (exceto para MT III) que é seguido de um decréscimo de transcritos, também paralelo aos teores de Cd na solução, aos 33 dias. Da mesma forma, 
existe uma indução de MT II e principalmente MT III na parte aérea, com o aumento da concentração de cádmio na solução, mais acentuada aos 11 dias. Estes resultados evidenciam a capacidade da cana-de-açúcar de tolerar e acumular $\mathrm{Cu}$ e $\mathrm{Cd}$, sugerindo um potencial fitorremediador para recuperação de áreas contaminadas com esses metais. 


\title{
EVALUATION OF THE SUGARCANE TOLERANCE (Saccharum spp.) TO METALS: METALLOTHIONEIN GENE EXPRESSION
}

\author{
Author: MARIA LORENA SERENO \\ Adviser: Prof. Dr. ANTONIO VARGAS DE OLIVEIRA FIGUEIRA
}

\section{SUMMARY}

Heavy metals are elements with high density $\left(>5\right.$ g.cm $\left.{ }^{-3}\right)$, naturally occurring in soils, and with the increase of anthropogenic activities has accelerated the release of these elements in ecosystems. Heavy metals can be highly toxic (e.g. Mercury; Lead; Cadmium) or toxic at high concentration (Zinc and Copper). Phytoremediation is a clean up technology based on the use of plants to remove pollutants from the environment or to transform them in less toxic forms to living organisms, with less environmental impact at a lower cost than physic-chemical methods. A crop to be successfully used to recover contaminated areas must be efficient in metal accumulation, must yield large amounts of biomass and to be able to adapt to contaminated conditions. Sugarcane (Saccharum spp.) presents physiological characteristics that allowed this crop to become widely adopted in tropical, with high 
biomass production and with genes associated with chelating peptides already identified by the Sugarcane genome project (SUCEST). In this work, metallothionein gene expression was investigated in sugarcane plantlets. The young plants were growth in $1 / 4$ Hoagland solution containing elevated levels of $\mathrm{Cu}^{+2}(50,100,250$ and $500 \mu \mathrm{M})$ or $\mathrm{Cd}^{+2}$ $(100,250$ and $500 \mu \mathrm{M})$. Metal concentration were determined in root and shoot tissues harvested at 11 and 33 days of treatment. The highest $\mathrm{Cu}$ doses $(250$ and $500 \mu \mathrm{M})$ killed the plants after 11 days of culture, however the effect of the lowest dosages were comparable to the control after 33 days of treatment. The plants were capable of accumulate large amount of $\mathrm{Cu}$ and $\mathrm{Cd}$, mainly in roots. All Cd dosages significantly limited growth, but without stopping it. Total RNA was analyzed for metallothionein Type I, II and III gene expression by northern. Results indicated that expression of the three types of metallothionein genes was constitutive, with more expression of MT I and MT II, in leaves and roots. MT I expression was greater in roots than in shoots. But MT II and MT III genes were more expresses in shoots. Metallothionein gene expression was poorly affected or not at all by $\mathrm{Cu}$. But for $\mathrm{Cd}$, there was an accumulation of MT transcripts in roots at 11 days slightly proportional to $\mathrm{Cd}$ concentration, except for MT III, which was followed by a decrease in transcripts, also parallel to Cd levels in solution at 33 days. Similarly, there as an induction of MT II and mainly MT III in shots with the increase of $\mathrm{Cd}$ concentration in solution, more pronounced at 11 days of treatment. These results demonstrated the ability of sugarcane to tolerate and accumulate $\mathrm{Cu}$ and $\mathrm{Cd}$, suggesting a potential application in phytoremediation of areas contaminated with heavy metals. 


\section{INTRODUÇÃO}

Existe atualmente uma grande preocupação dos efeitos que diversos poluentes orgânicos e inorgânicos possam ter sobre a saúde humana e animal, e o ambiente, pois a crescente industrialização das últimas décadas tem aumentado a liberação e a concentração desses compostos químicos potencialmente tóxicos na biosfera. Entre os poluentes, os metais pesados representam o maior contaminante industrial de solos, corpos de água, plantas e animais no ecossistema (Ghoshroy et al., 1998). Dentre as tecnologias disponíveis de descontaminação de ambientes afetados, a fitorremediação apresenta grande potencial em relação a métodos físico-químicos, tais como tratamento ou remoção física do solo, oferecendo menor impacto ambiental e custo de implementação (Salt et al., 1998).

O princípio da fitoremediação se baseia nos mecanismos de tolerância à acumulação de metais existentes nas plantas. Estes mecanismos estão relacionados à ocorrência de peptídeos quelantes de metais, como as metalotioneínas, que auxiliam direta ou indiretamente, a acumulação de metais pelas plantas (Cobbet et al., 2002). Uma cultura para ser utilizada com sucesso na recuperação de áreas contaminadas, deve ser eficiente na acumulação de metais, produzir grandes quantidades de biomassa e ser capaz de se adaptar as condições do ambiente contaminado. A cana-de-açúcar se 
apresenta como uma boa espécie candidata a ser usada na fitorremediação por suas características fisiológicas, com alta produtividade de biomassa e rusticidade, possuidora de genes que codificam peptídeos quelantes os quais já foram identificados no projeto genoma da cana-de-açúcar (SUCEST) (Figueira et al., 2001).

Este trabalho teve como objetivo caracterizar a regulação transcripcional de genes de metalotioneínas pelos metais $\mathrm{Cu}$ e $\mathrm{Cd}$ em cana-de-açúcar, utilizando a análise de northern em raízes e folhas de plântulas de cana cultivadas em condições de hidroponia para testar a hipótese que a expressão dos genes MTs é modulada pela presença de desses metais. 


\section{REVISÃO BIBLIOGRÁFICA}

\subsection{Contaminação ambiental}

A contaminação de solos e água com diversos poluentes químicos representa um grande problema atual, principalmente para o meio ambiente e à saúde humana e animal. A industrialização e urbanização progressiva têm exposto animais e vegetais a muitos elementos químicos potencialmente tóxicos. Entre estes, os metais pesados representam o maior contaminante industrial dos ecossistemas (Ghoshroy et al., 1998). As principais fontes de contaminação com metais pesados derivam de diversas atividades humanas, tais como metalurgia, mineração, fundição e galvanoplastia (Chaoui et al., 1997), indústrias de couro (Jordão et al., 1999), gases liberados pela queima de combustíveis fósseis como a gasolina, pesticidas (Gimeno-García et al., 1996; Malavolta, 1994), utilização de lodo de esgoto para fertilização na agricultura (Chaoui et al., 1997), aplicação de fertilizantes organofosforados (Schickler \& Caspi, 1999) e a fabricação e descarte de baterias (Oliveira et al., 2002), entre outros. Nas últimas cinco décadas, foram liberadas na biosfera 22.000 t de cádmio, 939.000 t de cobre, $783.000 \mathrm{t}$ de chumbo e 1.350 .000 t de zinco, como produto da industrialização global (Singh et al., 2003). 


\subsection{Tecnologia e métodos para descontaminação}

As tecnologias atualmente disponíveis para a descontaminação podem ser divididas em duas grandes categorias: fisico-química, incluindo eletrocinética, lavagem e/ou remoção e recolocação de solos contaminados e estabilização; e biológica. A eletrocinética utiliza uma corrente elétrica para fazer com que a água e os íons metálicos migrem através do solo até eletrodos aderidos a terra, onde os íons podem ser coletados e até processados para serem reciclados. A lavagem de solos contaminados envolve a separação de pequenas e grandes partículas com metais da terra, utilizando-se água contendo detergentes ou ácidos fracos, enquanto que na remoção do solo contaminado, grandes parcelas de terra são escavadas, extraídas e re-locadas em locais ou depósitos específicos. Já a estabilização consiste na redução da capacidade de lixiviação dos metais pesados, reduzindo a permeabilidade dos produtos à água ou mediante mudanças químicas que reduzam a solubilidade do metal (Romantschuk et al., 2000). A necessidade de métodos mais econômicos e eficientes para a remoção dos metais têm resultado no desenvolvimento de novas tecnologias de separação (Kefala et al., 1999).

As técnicas de biorremediação referem-se ao uso de microrganismos e plantas para a remediação de áreas contaminadas com poluentes. $O$ estudo da toxicidade dos metais em tais organismos é de grande preocupação porque estes se encontram entre os mais afetados pela contaminação (Gadd, 1990). Embora muitos mecanismos distintos atuem simultaneamente durante a bioacumulação e a bioadsorção, apenas alguns foram claramente identificados, envolvendo a remoção dos metais via 
mecanismos ativos ou passivos, respectivamente (Gadd \& White, 1993, Kapoor et al., 1999). A bioadsorção é baseada na capacidade dos metais se ligarem a vários materiais biológicos, tais como algas, leveduras, fungos e bactérias (Veglio \& Beolchini, 1997) e apresenta interesse para a indústria devido à capacidade de remoção de metais pesados dos efluentes pelos microrganismos (Kefala et al., 1999). Este método é independente do ciclo metabólico do microrganismo e é conhecido também por captação passiva (Kapoor et al., 1999). A abundante biomassa de fungos produzida como um subproduto nos processos industriais em larga escala, pode ser uma fonte mais viável economicamente de bioadsorventes de metais (Waihung et al., 1999; Kapoor et al., 1999). As cianobactérias também representam um potencial promissor para uso na bioremoção de metais pesados, pois são organismos com baixo requerimento nutricional (realizam fotossíntese e fixam o nitrogênio atmosférico), com distribuição ubíqua na natureza refletindo a ampla variedade de espécies e apresentando uma vasta faixa de propriedades fisiológicas e tolerância aos estresses ambientais. Na bioadsorção, os microrganismos apenas seqüestram o metal através de ligações de superfície. Por sua vez, no processo de bioacumulação os metais são concentrados através de uma combinação de reações de superfície, precipitações e formação de complexos intra- e extra-celulares. Porém, existem limitações práticas, sendo a mais significativa a inibição do crescimento celular quando a concentração dos íons do metal torna-se muito elevada. O processo ativo de biorremoção também requer fornecimento de nutrientes adequados, aeração e temperatura para o crescimento dos microrganismos. Entretanto, o fato de que muitos tratamentos convencionais de esgotos são hábitat de microrganismos sugere que 
tais limitações não impossibilitam sua aplicação em sistemas envolvendo a biorremoção de metais pesados (Dönmez \& Aksu, 1999).

A fitorremediação apresenta grande potencial em relação a métodos físico-químicos, oferecendo menor impacto ambiental e custo de implementação (Salt et al., 1998, Singh et al., 2003). O princípio da fitorremediação se baseia nos mecanismos de tolerância à acumulação de metais existentes nas plantas, de forma a manter as funções celulares mesmo na presença de altas concentrações de metais. Estes mecanismos incluem a compartimentalização dos metais em estruturas sub-celulares; exclusão e/ou diminuição do transporte através da membrana; e a formação de peptídeos quelantes, ricos em cisteínas, como as fitoquelatinas e metalotioneínas, que auxiliam direta ou indiretamente, na acumulação de metais pelas plantas (Cobbet \& Goldsbrough, 2002).

As plantas possuem sistemas de absorção e efluxo responsáveis pelo controle das concentrações ótimas de nutrientes no interior celular (Fox \& Guerinot, 1998). Vários metais são essenciais ao metabolismo celular (ex. Cu, Zn, Mn, Fe), participando como co-fatores de diversas enzimas em várias reações bioquímicas. Entretanto, metais não-essenciais (ex. $\mathrm{Cd}, \mathrm{Pb}, \mathrm{Hg}, \mathrm{Ag}$ e $\mathrm{Ni}$ ) apresentam propriedades químicas similares aos essenciais e, portanto, são também absorvidos pelos vegetais (Goldsbrough, 1998). Os metais, essenciais ou não, são tóxicos para as plantas quando presentes em altas concentrações, por apresentar uma alta reatividade, promovendo a formação de espécies ativas de oxigênio.

Além das fitoquelatinas e metalotioneínas, outro mecanismo de defesa desenvolvido pelas plantas e microrganismos para tolerância à exposição aos metais 
pesados, é a produção de um sistema antioxidante de defesa, que inclui componentes de baixa massa molecular tais como glutationa e ascorbato, e um sistema de enzimas antioxidantes capazes de remover, neutralizar ou limpar radicais livres, que inclui a superóxido dismutase (SOD), catalase (CAT) e glutationa redutase (GR), entre outros (Scandalios, 1993).

\subsection{Metalotioneínas (MTs)}

Metalotioneínas constituem uma superfamília de proteínas de baixo peso molecular $(<10 \mathrm{kDa})$ com distribuição ubíqua na natureza, as quais contêm um alto teor de metais e enxofre, podendo contribuir com mais de $20 \%$ do peso dessa proteína. Íons

metálicos bivalentes $\left(\mathrm{Zn}^{2+}, \mathrm{Cu}^{2+}, \mathrm{Cd}^{2+}\right)$ ligam-se aos grupos tióis dos resíduos de cisteínas (Fowler et al., 1987; Binz \& Kagi, 2001). As MT foram descritas em 1957 quando Margoshes \& Vallee (1957) identificaram no córtex renal de cavalo uma proteína quelante de cádmio responsável pelo acúmulo desse elemento nesse tecido. Desde então, sua presença tem sido detectada em espécies animais, plantas superiores, algas, e microrganismos eucarióticos e procarióticos.

Em organismos procarióticos, a presença de proteínas similares as MTs tem sido observada em vários grupos (Escherichia coli, Thiobacillus, Pseudomonas e outros) [Higham et al., 1984; Maclean et al., 1972; Morozzi et al., 1993]. A similaridade entre MT de fungos e animais está restrita aos resíduos de cisteínas, com baixa identidade de nucleotídeos (Zhou \& Goldsbrough, 1994). 
As plantas contêm genes que em termos estruturais e funcionais são homólogos a genes de MT de animais e fungos (Robinson et al., 1993; Rauser, 1999). A primeira proteína de MT de plantas foi isolada de embriões de trigo $\left(\mathrm{E}_{\mathrm{c}}\right)$, com cisteínas em três domínios, e com capacidade de se ligar ao zinco (Lane et al., 1987). Depois disso, genes tipo MTs foram relatados em outras espécies mono- e dicotiledôneas, entre elas, milho, trigo e soja, (de Framond, 1991; Kawashima et al., 1991, Foley \& Singh, 1994). Em Arabidopsis thaliana, cinco genes de MT foram isolados e caracterizados (Zhou \& Goldsbrough, 1995). Mais recentemente, o banco de dados de EST de Arabidopsis revelou a presença de mais dois genes e um pseudogene nesta espécie (Cobbett \& Goldsbrough, 2002). Genes de MTs codificando para proteínas ricas em cisteína foram identificados em inúmeras espécies e tecidos vegetais: ervilha, arroz, algodão, grão de bico, tomate, bata doce e alcachofra de Jerusalém, entre outros (Hsieh et al., 1995; Hudspeth et al., 1996; Muñoz et al., 1998 Giritch et al., 1998; Huang et al., 2001; Chen et al., 2003; Chang et al., 2004).

A maioria das proteínas previstas de plantas não foi isolada, exceto em trigo (Lane et al., 1987) e Arabidopsis (Murphy et al., 1997), e a capacidade de cada proteína em se ligar a metais não foi demonstrada, exceto para $\mathrm{E}_{\mathrm{c}}$ de trigo. Portanto, a expressão de metalotioneínas tem sido inferida principalmente a partir de seqüências de DNA/ mRNA.

Os mRNAs de MT têm sido identificados utilizando abordagens de expressão diferencial por diversos tratamentos, principalmente em resposta a diversos fatores ambientais (Snowden \& Gardner, 1993, Choi et al., 1996; Fordham-Skelton et al., 1998; Ma et al., 2003); durante o desenvolvimento (Chatthai et al., 1997; Muñoz et 
al., 1998); ou freqüentemente no curso de vários projetos de seqüenciamento de EST (Etiquetas de Seqüências Expressas) (Goldsbrough, 1999; Figueira et al., 2001); ou mediante SAGE (Serial analysis of gene expression) (Matsumura et al.,1999; Gibbings et al., 2003), indicando que vários desses genes de MT de plantas são altamente expressos. A localização mais detalhada dos mRNAs de MTs ou a atividade de promotores destes genes foi relatada para um pequeno número de casos, utilizando hibridização in situ e expressão de genes repórteres (Laplaze et al., 2002; Guo et al., 2003).

A função das metalotioneínas é ainda desconhecida, mas as evidências indicam que elas possuem um papel importante na homeostasia de metais, provavelmente associadas com transporte. A síntese de MT pode ser também induzida por diversos agentes, tais como hormônios, fatores de crescimento, promotores de tumor, estresses físico-químicos e muitas outras substâncias químicas, em condições in vivo e em culturas celulares (Kagi, 1991; Fordham-Skelton et al., 1998; Cobbett \& Goldsbourgh, 2002).

\subsubsection{MTs: Classificação}

O primeiro sistema de nomenclatura de MTs foi introduzido em 1978 (Nordberg \& Kojima, 1979), o qual foi ampliado em 1985 pela introdução de uma subdivisão de todas as MTs em três classes (I-II-III) com base nas características estruturais (Fowler et al., 1987). A Classe I contém a maioria das MTs de animais (Kagi, 1991), de Neurospora crassa e outros fungos (Munger et al., 1987). A classe II 
inclui polipeptídeos com nenhuma similaridade ou com relações evolutivamente distantes das MTs de mamíferos, como são os polipeptídios do ouriço de mar, nematóides, leveduras (Saccharomyces cerevisiae e Candida glabrata), cianobactéria (Synechococcus sp), e plantas superiores (Kagi, 1991; Robinson et al., 1990; Robinson et al., 1993). Nas Classes I e II encontram-se proteínas codificadas por genes e na Classe III encontram-se polipeptídeos não diretamente codificados por genes, compostos de unidades atípicas (como por exemplo, $\gamma$-glutamilcisteína e fitoquelatinas) (Kagi, 1991; Cobbett \& Goldsbourgh, 2002).

Com o crescimento do número de seqüências de MT essa subdivisão tornou-se inadequada. Embora mantendo a aceitável definição de MTs, o comprimento de suas seqüências, a composição de seus aminoácidos; os números e repartições das cisteínas são agora conhecidos por serem altamente variáveis. Adicionalmente, as seqüências de genes agora disponíveis freqüentemente contêm elementos potencialmente relacionados a propriedades funcionais das MTs que não foram consideradas no sistema de classificação. Dessa maneira foi proposto um novo sistema de classificação, baseado nas similaridades das seqüências e nas relações filogenéticas (Kojima et al., 1999). Assim, a superfamília da MT fica subdividida em famílias, subfamílias, subgrupos, isoformas e alelos isolados (Binz \& Kägi, 2001).

A maioria das MTs de plantas contém dois domínios ricos em cisteína separados por um domínio central sem cisteínas, mas com amino ácidos hidrofóbicos e aromáticos (exclusivo de plantas). Todas estas MTs classe II de plantas podem ser subclassificadas com base na seqüência de amino ácidos em quatro tipos de acordo com a 
distribuição de resíduos de cisteína nos dois domínios (Robinson et al., 1993, Cobbett \& Goldsbrough, 2002). Metalotioneínas do Tipo I possuem 6 pares de cisteína, agrupadas num arranjo Cis-X-Cis, distribuídas igualmente nos dois domínios, enquanto que as proteínas do Tipo II contêm 4 pares de Cis no extremo amino terminal, iniciando por uma configuração Cis-Cis e terminando o primeiro domínio com Cis-X-X-Cis, não havendo outras diferenças para os outros três pares de cisteína no extremo carboxi terminal (Robinson et al., 1993)[Figura 1]. As MTs do Tipo III exibem um arranjo de cisteínas diferente, principalmente na terminação amino, e genes desse tipo já foram isolados de Arabidopsis, kiwi, maçã, uva e dendê (Murphy et al., 1997; Ledger \& Gardner, 1994; Reid \& Ross, 1997; Davies \& Robinson, 2000; Abdullah et al., 2002). As MTs relacionadas ao gene de trigo $\mathrm{E}_{\mathrm{c}}$, expressos durante o desenvolvimento de embriões são classificadas como do Tipo IV.

\subsubsection{MTs: Genes e expressão}

As MTs dos vários tipos são codificadas por pequenas famílias gênicas, com dois ou mais genes, mesmo no reduzido genoma de Arabidopsis onde 7 genes, membros dos 4 tipos de metalotioneínas, foram relatados (Cobbett e Goldsbrough, 2002). Análises dos bancos de dados de seqüências de arroz (www.tigr.org; www.gramene.org) indicaram a presença de 9 cópias de genes MTs distribuídos em vários cromossomos, sendo cinco do tipo MT I, dois tipo MT II e um de cada os tipos MT III e MT IV. Em algodão foram identificados 3 genes tipos MT I (Hudspeth et al., 1996) e em tomate três genes tipo MT II (Giritch et al., 1998). Cada gene possui 
padrões de expressão temporal e espacial distintos. De forma geral, em Arabidopsis as MTs do Tipo I são mais expressas em raízes do que em folhas, enquanto que os transcritos de MT do Tipo II e III são mais detectados em folhas do que raízes (Zhou \& Goldsbrough, 1995; Murphy et al., 1997; Guo et al, 2003). Em cana-de-açúcar, no projeto SUCEST, foram encontrados pelo menos 54 agrupamentos de ESTs, todos com a seqüência completa, com valores $E<10^{-7}$, derivados de 849 seqüências (Figueira et al., 2001). Esses agrupamentos foram alinhados com representantes de MT de outras espécies e classificados nos quatro tipos de MTs (Figura 1). Entre esses agrupamentos, 27 foram classificados como Tipo I, enquanto que 21 grupos como do Tipo II. Cinco grupos foram classificados como MT do Tipo III, e apenas um grupo foi identificado como MT do Tipo IV. Dos 291.689 ESTs seqüenciados no projeto SUCEST, um total de $849(0,29 \%)$ codificavam metalotioneínas, expressos nas diversas bibliotecas (Figueira et al., 2001). O nível de expressão variou de 0,005\% (1/18523) na biblioteca de cDNA de flores até 1,5\% (156/10336) na de semente. Os transcritos de MT Tipo I foram os mais abundantes, com um total de 501 ESTs, principalmente em bibliotecas de sementes, e também de raízes. Os transcritos de MT do Tipo II em cana foram o segundo mais abundantes (324) em bibliotecas de parte aérea, em contraste com os transcritos do Tipo I. Garcia-Hernandez et al (1998) observou a mesma tendência para os genes MT1 e MT2 de Arabidopsis, concluindo que essas MTs provavelmente possuem papéis distintos na homeostasia de metais. Apenas 24 ESTs continham transcritos de metalotioneína do tipo III. O nível de transcritos de MT em cana sob condições não indutoras de estresse é elevado indicando que esses genes são expressos constitutivamente, principalmente aquelas do Tipo I. Transcritos de MTs do Tipo I 
foram os mais freqüentes $(2,9 \%)$ em ESTs seqüenciados de uma interação compatível entre arroz e brusone (Kim et al., 2001).

\subsubsection{Possíveis funções associadas às MTs}

A pesar das metalotioneínas terem sido estudas por décadas, sua função em plantas permanece desconhecida. Em mamíferos ficou bem estabelecido que as MTs mantem a homeostase dos elementos zinco e cobre e protegem as células da toxidez e estresse oxidativo do cádmio (Coyle et al., 2002). Uma vez que as MTs de plantas se ligam eficientemente a metais (Evans et al., 1992; Murphy et al., 1997), e alguns genes MTs são regulados transcripcionalmente por metais (Murphy \& Taiz, 1995; Cobbett \& Goldsbrough, 2002), sugeriu-se que as metalotioneínas poderiam ter um papel importante na tolerância e homeostasia de metais também nas plantas.

Existem indicações da importância de MTs para tolerância a cobre em Arabidopsis, e que podem estar associadas a homeostasia de metais em plantas, regulando a concentração de certos íons (Robinson et al., 1993; Zhou \& Goldsbrough, 1995). Transcritos de MT1 se acumulam em folhas de Arabidopsis expostas a $\mathrm{Cu}^{2+}$, e

em menor escala por $\mathrm{Zn}^{2+}$ e $\mathrm{Cd}^{2+}$, enquanto que aqueles de $M T 2$ aumentam na presença de $\mathrm{Ag}^{+}, \mathrm{Cd}^{2+}, \mathrm{Zn}^{2+}, \mathrm{Ni}^{2+}$ ou choque térmico (Zhou e Goldsbrough, 1994). A expressão constitutiva de PsMT em raízes de ervilha em soluções nutritivas na ausência de altas dosagens de metais parece estar associada à deficiência de ferro e ao conseqüente acúmulo de cobre nas raízes (Robinson et al., 1993). Genes de MTs de Arabidopsis (MT1a e MT2a) quando expressos em leveduras mutantes para ausência do gene de 
metalotioneína (CUP1), reconstituíram a tolerância a cobre e aumentaram a tolerância a cádmio, em função do gene usado, sendo que $M T 2 a$ restabeleceu o crescimento em maiores níveis de Cd (Zhou \& Goldsbrough, 1994). O mesmo gene MT2a de Arabidopsis restabeleceu o crescimento parcial de um mutante de cianobactéria (deleção do gene smtA) na presença de Zn (Fordham-Skelton et al., 1997). Recentemente, o gene tyMT, um gene tipo MT-II isolado a partir de Typha latifolia (Zhang et al., 2004), foi introduzido em leveduras mutantes altamente sensíveis a metais $\left(\operatorname{cup} 1^{\Delta}\right)$, permitindo a sobrevivência e crescimento das células em meios com concentrações altíssimas de metais: $0,1 \mathrm{mM} \mathrm{Cd}, 2 \mathrm{mM} \mathrm{Cu}, 1 \mathrm{mM} \mathrm{Zn}$ e $6 \mathrm{mM}$ Pb. Por outro lado, a super-expressão do gene tyMT em plantas mutante de Arabidopsis thaliana (Columbia-0) (Zhang et al., 2004), incrementou a tolerância a cobre e cádmio, em comparação com o controle. Estes resultados são consistentes com os obtidos num trabalho, onde plantas transgênicas de A thaliana transformadas com o gene MT I de ervilha (PsMTa) acumularam 8 vezes mais cobre que os controles não transformados, e quando expresso em E. coli aumentou a capacidade de acúmulo de cádmio e cobre nas células, em meio enriquecido para esses metais (Fordham-Skleton et al., 1997).

A ausência de indução de MT por cobre em outros sistemas e/ou genes pode advir de uma expressão elevada antes da presença do metal; ou mesmo uma falta de indução por metais (Goldsbrough, 1999).

A expressão de genes de MT pode ser afetada por outros estímulos associados ao estresse, tais como choque térmico; estresse salino; deficiência de nutrientes e de açúcar; ferimentos e infecção viral; assim como também, por estímulos relacionados com processos de desenvolvimento, isto é, amadurecimento; 
embriogênesis, desenvolvimento do grão de pólen; alongamento do epicótilo; senescência; e abscisão, (Hsieh, et al., 1996; Choi et al., 1996; Reynolds \& Crawford, 1996; Chattai et al., 1997; Fordham-Skelton et al., 1998; Muñoz et al., 1998; Davies \& Robinson, 2000; Giordani et al., 2000; Guo et al., 2003).

Uma cultura para ser utilizada com sucesso na recuperação de áreas degradadas, além de ser eficiente na acumulação de metais, também precisa ter características fisiológicas que permitam alta produção de biomassa e adaptação ao ambiente a ser descontaminado, tolerando os efeitos do estresse oxidativo decorrente da exposição a metais. A cana-de-açúcar apresenta potencial para a fitorremediação de áreas contaminadas com metais por suas características fisiológicas, com alta produtividade de biomassa e rusticidade, e por possuir genes que codificam os peptídeos quelantes já identificados no projeto genoma da cana-de-açúcar (SUCEST), (Figueira et al., 2001). Estudos indicam uma boa tolerância de cana-de-açúcar ao cádmio, sendo que plantas jovens foram capazes de tolerar concentrações de até $5 \mathrm{mM}$ em solução nutritiva (Fornazier et al., 2002). Conhecer a capacidade acumulativa de metais irá permitir a manipulação genética e a indução da hiper-acumulação, fundamentais para a descontaminação de áreas com alto teores destes poluentes. 
Metalotioneína Tipo I SCSFHR1044C11.g SCQSHR1020G10.g SCAGLR1021E11.g SCRLFL4058DO4.g SCRFLR2034A10.g SCUTLR2008B11.g SCCCLR2003D01.g

Consenso SCCCLB1025A03.g

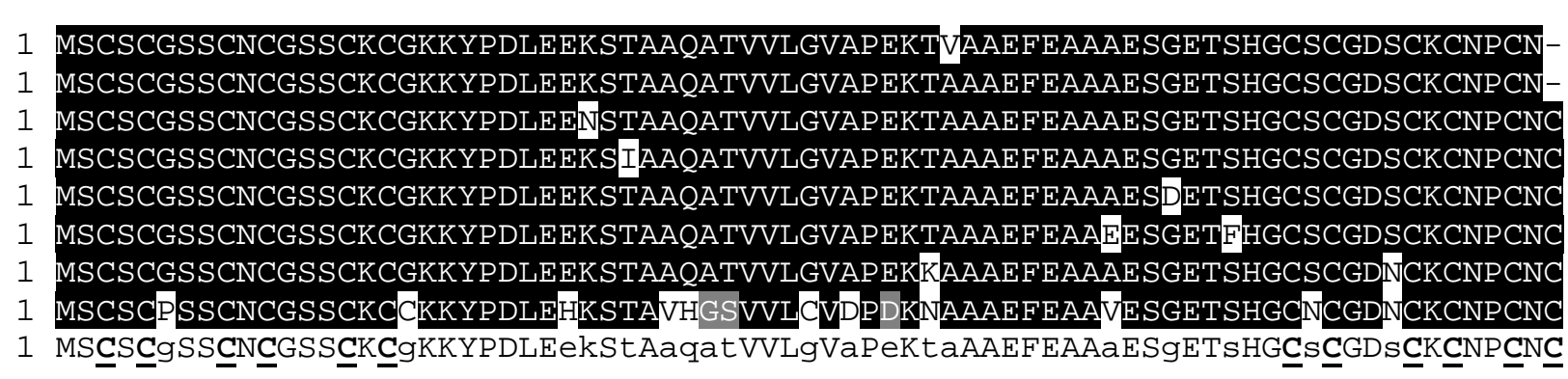

Metalotioneína Tipo II SCACAM2042F-4.g SCJLFL3014G10.g SCJFRZ2006EO2.g SCQGFL3053E07.g SCRUFL3063A10.g SCVPHR1093D07.g SCBGHR1060D06.g SCCCRZ2002DO9.g Consenso

Metalotioneína Tipo III SCSGHR1070E07.g SCACLR2014B12.g SCUTLR2023H06.g SCSGHR1072H01.g Consenso

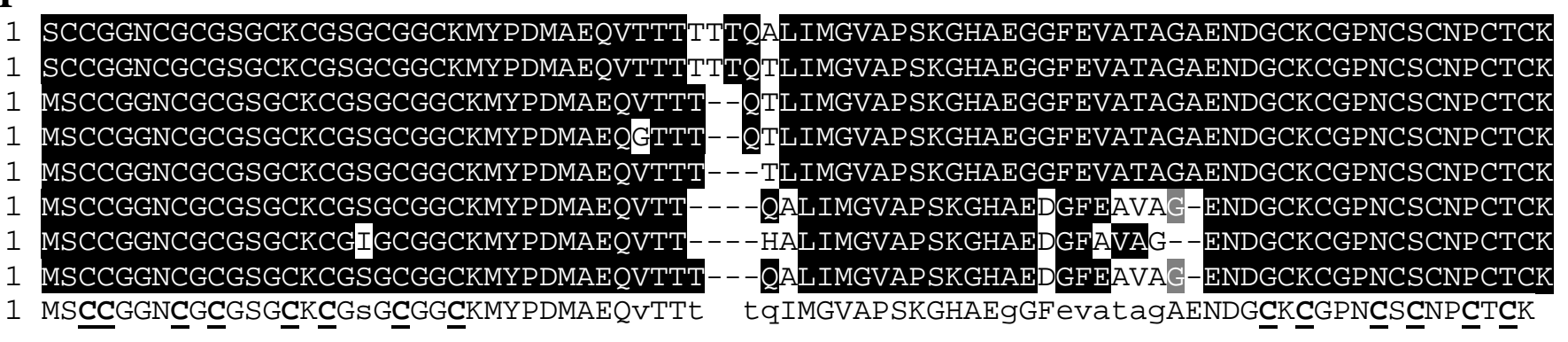

1 MSGTCGNCDCADKTQCTKKGDSYGAVVVDTESRVEIVEEEVTVAEHDGCKCGTSCSCGTSCSCGK

1 MSGTCGNCDCADKTQCTKKGDSYGAVVVHTESRVEIVEEEVTVAEHDGCKCGTSCSCGTSCSCGK

1 MSGTCGNCDCVDKTQCTKKGGSYGAVVVHTESRVEIVEEEVTVAEHDGCKCGTSCSCGTSCSCGK

1 MSGTCRNCDCVDKTQCTTKGGCYGAVGVHTESRVDIVEEDVIVAEHDGCKCGVSCSCRSSCSWGK

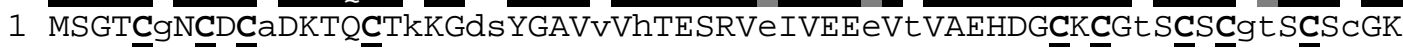

Figura 1 - Seqüência prevista de amino ácidos para os três tipos de metalotioneínas identificas em cana-de-açúcar, com consenso. Os resíduos de cisteínas encontram-se em negrito e sublinhados no consenso 


\section{MATERIAL E MÉTODOS}

\subsection{Material Vegetal}

Foram obtidas plântulas derivadas de culturas de meristemas de cana-deaçúcar da variedade 'SP80-3280', produzidas na biofábrica da COPERSUCAR, Piracicaba, SP. Foram fornecidos frascos de plantas in vitro na fase III (caracterizada pela regeneração da parte aérea e indução de enraizamento). O material foi replicado e

multiplicado no meio Murashige \& Skoog (MS), suplementado com $0,12 \mathrm{mg} \mathrm{L}^{-1}$ de 2,4D e $0,01 \mathrm{mg} \mathrm{L}^{-1} \mathrm{BAP}$.

\subsection{Cultivo em hidroponia}

O sistema de hidroponia foi estabelecido em casa de vegetação localizada no Departamento de Ciências Biológicas da ESALQ/USP (Laboratório de Plantas Cultivadas sob Condições de Estresse). As plântulas na fase III foram aclimatadas em bandejas com 1/20 da concentração solução nutritiva de Hoagland \& Arnon (1953). A cada 15 dias, a solução foi trocada para concentrações crescentes de força iônica para 
adaptação à hidroponia, até atingirem a concentração usada nos experimentos, 1/4 da solução nutritiva completa [solução $1 \mathrm{X}$ : $5 \mathrm{mM} \mathrm{Ca}\left(\mathrm{NO}_{3}\right) .4 \mathrm{H}_{2} \mathrm{O} ; 5 \mathrm{mM} \mathrm{KNO} \mathrm{KN}_{3} ; 1 \mathrm{mM}$ $\mathrm{KH}_{2} \mathrm{PO}_{4} ; 2 \mathrm{mM} \mathrm{MgSO} 47 \mathrm{H}_{2} \mathrm{O} ; 7,15 \mathrm{mg} \mathrm{L}^{-1} \mathrm{H}_{3} \mathrm{BO}_{3} ; 4,52 \mathrm{mg} \mathrm{L}^{-1} \mathrm{MnCl}_{2} 4 \mathrm{H}_{2} \mathrm{O} ; 0,55 \mathrm{mg}$ $\mathrm{L}^{-1} \mathrm{Zn} \mathrm{SO} 4.5 \mathrm{H}_{2} \mathrm{O} ; 0,2 \mathrm{mg} \mathrm{L}{ }^{-1} \mathrm{CuSO}_{4} .5 \mathrm{H}_{2} \mathrm{O} ; 0,225 \mathrm{mg} \mathrm{L} \mathrm{Na}_{2} \mathrm{MoO}_{4}$; Fe-EDTA]. O sistema de hidroponia foi conectado por mangueiras a um compressor isento de óleo que forneceu $44 \mathrm{~L}_{\text {ar dia }}{ }^{-1}$ a cada bandeja, trabalhando 15 min a cada hora.

\subsection{Experimento com metais pesados}

Foi conduzido um experimento avaliando as concentrações crescentes de $\mathrm{Cu}(50,100,250$ e $500 \mu \mathrm{M})$ e $\mathrm{Cd}(100,250$ e $500 \mu \mathrm{M})$. Cada tratamento continha 4 plantas por vaso, repetidos em 3 vasos com capacidade de 2,8 L cada um. Os tratamentos controle iniciaram-se simultaneamente com os experimentos de cobre ou cádmio, estabelecendo-se nas mesmas condições experimentais, embora sem a adição de metais pesados. $\mathrm{O} \mathrm{pH}$ da solução iniciou-se em 6,0 e foi monitorado freqüentemente durante a condução dos experimentos. As plantas foram distribuídas homogeneamente em cada tratamento, segundo seu peso fresco. Esse experimento teve a duração de 33 dias, e foi realizada uma coleta de plantas aos 11 dias. Foram avaliados pesos iniciais e finais, e os tecidos (separados em raízes e parte aérea) foram armazenados a $-80^{\circ} \mathrm{C}$ para serem utilizados posteriormente na extração de RNA para análise de expressão de metalotioneínas e determinação de concentração de metais nos tecidos. 


\subsubsection{Determinação de metais pesados nos tecidos de cana-de-açúcar}

A quantificação da concentração dos elementos químicos foi realizada pela técnica analítica Fluorescência de Raios X por Dispersão de Energia (EDXRF), em equipamento disponível no Laboratório de Instrumentação Nuclear do Prof. Dr. Virgílio Franco do Nascimento, da Divisão de Desenvolvimento de Métodos e Técnicas Analíticas e Nucleares, do CENA-USP. Para tal, as plantas foram coletadas, separadas em parte aérea (folha + colmo) e raiz, lavadas em água corrente, enxaguadas em água destilada não estéril, e secas. As amostras foram secas durante 192 horas (8 dias) a $60^{\circ} \mathrm{C}$, moídas a 20 mesh e em seguida $1 \mathrm{~g}$ de cada amostra foi colocada em recipiente apropriado para EDXRF, prensada a $2 \mathrm{t} \mathrm{cm}^{-2}$ e levada diretamente para análise, sem passar por nenhum tipo de pré-tratamento químico. Quando necessário, as amostras foram completadas com material controle moído, parte aérea ou raiz, até atingir $1 \mathrm{~g}$ de material seco requerido na análise.

A excitação foi feita com raios X Mo-Ka de 17,44 keV, provenientes de um tubo de raios $\mathrm{X}$ com alvo de Mo e filtro de $\mathrm{Zr}$, operado a $25 \mathrm{kV}$ e $10 \mathrm{~mA}$, possibilitando a detecção do elemento $\mathrm{Cu}$ pelos seus raios $\mathrm{X}$ característicos $\mathrm{K} \alpha$. As amostras foram excitadas por $500 \mathrm{~s}$, sendo os raios $\mathrm{X}$ detectados por um espectrômetro multicanal, baseado em detector semicondutor de $\mathrm{Si}(\mathrm{Li})$ e eletrônica nuclear convencional. A concentração do marcador foi estimada através das intensidades dos raios $\mathrm{X}$ característicos, levando-se em conta o efeito matriz. Para o elemento $\mathrm{Cd}$, utilizou-se uma fonte de Am-241 na excitação. Esta fonte emite raios gama de 59,5 keV 
e com isto é possível excitar o $\mathrm{Cd}$, que necessita no mínimo $22 \mathrm{keV}$ para se excitar e produzir raios X. A validação da metodologia foi realizada analisando-se uma amostra de referência certificada (hay powder, V-10) produzida pela Agência Internacional de Energia Atômica (IAEA,Viena, Aústria).

\subsection{Escolha de clones para serem utilizados como sonda}

Os clones EST de cana-de-açúcar identificados como MTs dos quatro tipos (Figueira et al., 2001) foram requisitados ao Centro Brasileiro de Estocagem de Genes (BCC- Brazilian Clone Collection Centre, Jaboticabal - SP), num total de 34 clones agrupados em 16 clusters sendo 4 do tipo MT I, 8 tipo MT II, 2 tipo MT III e 1 tipo MT IV. As culturas contendo os clones foram crescidas em meio LB líquido contendo $100 \mu \mathrm{g} \mathrm{mL} L^{-1}$ de ampicilina a $37^{\circ} \mathrm{C}$ e sob agitação $(150 \mathrm{rpm})$. Os plasmídeos foram purificados usando o kit Concert Rapid Plasmid Purification Systems (Invitrogen Co, Carlsbad, CA, EUA). As reações de seqüenciamento foram preparadas com um quarto do volume recomendado pelo kit ABI Prism BigDye terminator sequence (Applied Biosystems, Foster City, CA, EUA) acrescentado-se 100 ng de DNA plasmidial, 2,5X de tampão Save Money (200 mM Tris- $\mathrm{HCl} \mathrm{pH}$ 9,0; $5 \mathrm{mM}$ $\mathrm{MgCl}_{2} \cdot 6 \mathrm{H}_{2} \mathrm{O}$ ) e $0,1 \mu \mathrm{g} \mu \mathrm{L}^{-1}$ dos primers foward (T7) ou reverse (SP6). A reação de amplificação foi estabelecida com o seguinte perfil: desnaturação inicial 5 min a $96^{\circ} \mathrm{C}$; seguido de 35 ciclos de $45 \mathrm{~s} \mathrm{a} 96^{\circ} \mathrm{C} ; 30 \mathrm{~s}$ a $52^{\circ} \mathrm{C} ; 2$ min a $60^{\circ} \mathrm{C}$, finalizando com 4 min a $60^{\circ} \mathrm{C}$. Os produtos amplificados foram precipitados com $95 \%$ etanol e $3 \mathrm{M}$ acetato de 
sódio, seguido de duas lavagens com $75 \%$ etanol. O pellet foi seco a $37^{\circ} \mathrm{C}$ por $20 \mathrm{~min}$, e ressuspenso em tampão de seqüenciamento $(80 \%(\mathrm{v} / \mathrm{v})$ formamida deionizada; $20 \%$ loading buffer), para carregamento em gel de poliacrilamida para análise em seqüenciador automático 377 ABI-Prism (Applied Biosystems) do Departamento de Fitopatologia da ESALQ/USP, sob a responsabilidade do prof. Dr. Luis Eduardo Aranha Camargo.

As seqüências foram analisadas via blastn contra o banco de dados de reads e cluster-CAP3 do SUCEST e contra o GeneBank do NCBI utilizando-se a ferramenta do Blast 2 Sequences (http://www.ncbi.nlm.nih.gov/blast/bl2seq/bl2.html).

\subsubsection{Purificação de clones EST para confecção de sondas}

Os reads que tiveram suas seqüências confirmadas foram escolhidos como sondas para as análises de Southern e northern, considerando aquelas seqüências mais próximas da região 5' do consenso do cluster. As sondas foram preparadas a partir da purificação de produtos amplificados por PCR, seguido de digestão para remoção de pequenos trechos do vetor. Os clones foram amplificados por uma reação de PCR com $25 \mu \mathrm{L}$ de volume final, contendo $1 \mathrm{x}$ de tampão comercial de PCR (Invitrogen), 2,5 mM de $\mathrm{MgCl}_{2} ; 50$ ng dos primers reverse (SP6) e forward (T7) cada; $1 \mathrm{U}$ Taq polimerase (Invitrogen); 0,2 mM de cada dNTPs; e $150 \mathrm{ng}$ de DNA molde. As reações foram amplificadas em termociclador Perkin-Elmer 9700 programado para 3 min a $94^{\circ} \mathrm{C}$, seguido de 35 ciclos de 1 min a $94^{\circ} \mathrm{C}, 30$ s a $52^{\circ} \mathrm{C}, 1 \min$ e 30 s a $72^{\circ} \mathrm{C}$, finalizando com 
10 min a $72^{\circ} \mathrm{C}$. Os produtos foram então re-amplificados utilizando-se as mesmas condições. O produto final foi quantificado em gel de $1 \%$ agarose em TAE, e digeridos utilizando as enzimas SmaI e XbaI, ou EcoRI e HindIII com $1 \mathrm{U}$ por $\mu \mathrm{g}$ de DNA por $1 \mathrm{~h}$ a $37^{\circ} \mathrm{C}$. As reações de digestão foram aplicadas em gel de $1 \%$ agarose e os fragmentos referentes às sondas foram visualizado e cortados do gel, e purificados utilizando o kit GFX (Amersham Biosciences). A concentração de DNA de cada purificação foi determinada indiretamente pelo programa Kodak Digital Science 1D (Kodak, Japão), sendo então preparadas diluições para a concentração de $10 \mathrm{ng} \mu \mathrm{L}^{-1}$ para utilização nas reações de marcação de sondas.

\subsection{Extração de DNA de cana-de-açúcar}

Foram colhidas folhas tenras ("palmito") da variedade 'SP80-3280' na Estação Experimental COPERSUCAR (Piracicaba, - SP), para extração de DNA utilizando o protocolo proposto por Aljanabi et al. (1999). Resumidamente, cerca de 1,5g de folhas do palmito foram moídas em $\mathrm{N}$ líquido em moedor de café, e transferido para tubo de polipropileno de $50 \mathrm{~mL}$. Em seguida, foram adicionados $2 \mathrm{~mL}$ de solução 5\% N-lauryl-sarcosine; $2 \mathrm{~mL}$ de 10\% PVP; 2 mL de solução 20\% CTAB pré-aquecida; e 6 mL de tampão de homogeneização (200 mM Tris-HCl pH 8,0; 50 mM EDTA pH 8,0; 2,2 M NaCl; 2\% CTAB; 0,06\% sulfito de sódio). O tubo foi misturado gentilmente por inversão e incubado a $65^{\circ} \mathrm{C}$ por $60 \mathrm{~min}$, agitando ocasionalmente. As amostras foram então resfriadas a temperatura ambiente, e um volume igual de fenol: clorofórmio: 
álcool isoamílico (25: 24: 1) foi adicionado. A mistura foi agitada manualmente por 2 min e em seguida centrifugada a $10.000 \mathrm{~g}$ por $10 \mathrm{~min}$. A fase aquosa foi transferida para novo tubo e um volume igual de isopropanol gelado, seguido de $2 \mathrm{~mL}$ de $5 \mathrm{M} \mathrm{NaCl}$ foram acrescentados. A solução foi incubada a $-20^{\circ} \mathrm{C}$ por pelo menos $1 \mathrm{~h}$. O DNA precipitado foi centrifugado a $10.000 \mathrm{~g}$ por $10 \mathrm{~min}$, lavado com $10 \mathrm{~mL}$ de etanol $70 \% \mathrm{e}$ novamente centrifugado. $O$ pellet foi transferido para um tubo de $1,5 \mathrm{~mL}$ e ressuspendido em 200-400 $\mu \mathrm{L}$ de TE com RNAse $\left(50 \mu \mathrm{gL}^{-1}\right)$. O tubo foi incubado por 30 min a $37^{\circ} \mathrm{C}$ e armazenado a $-20^{\circ} \mathrm{C}$. A concentração do DNA total foi quantificada usando fluorímetro DyNA Quant 200 e/ou eletroforese em gel de 0,8\% agarose em tampão TAE (40 mM Tris-acetato; 1 mM EDTA).

\subsubsection{Análise de Southern}

Vinte e cinco $\mu \mathrm{g}$ de DNA genômico de cana-de-açúcar foram digeridos com as enzimas EcoRI, EcoRV, DraI e HindIII a $37^{\circ} \mathrm{C}$ por $7 \mathrm{~h}$. Outras enzimas de corte freqüente foram utilizadas inicialmente (AluI, HaeIII, MboI). As amostras, juntamente com marcador de peso molecular $(1 \mu \mathrm{g} \lambda$-Lambda-HindIII) e $1 \mathrm{ng}$ de sonda como controle positivo foram submetidas a eletroforese em gel de agarose $0,8 \%$, contendo $0,15 \mu \mathrm{g}$ de brometo de etídeo por $\mathrm{mL}$ de gel, em 0,5 X TBE (45 mM Tris borato; $1 \mathrm{mM}$ EDTA) por $15 \mathrm{~h}$ a $1,5 \mathrm{~V} \cdot \mathrm{cm}^{-1}$. Em seguida, o gel era tratado com solução de depurinação $(0,25 \mathrm{M} \mathrm{HCl})$ por 10 min, desnaturado com 2 lavagens em 1,5 M NaCl e $0,5 \mathrm{M} \mathrm{NaOH}$ por $15 \mathrm{~min}$, e neutralizado com 1,5 M NaCl; 0,5 M Tris- $\mathrm{HCl} \mathrm{pH}$ 7,0 por 30 
min. A transferência por capilaridade do DNA para a membrana nylon Hybond XL (Amersham) foi feita com 10X SSC [1,5 M NaCl; $150 \mathrm{mM} \mathrm{Na}{ }_{3}$ Citrato. $\left.2 \mathrm{H}_{2} \mathrm{O}\right]$ por $18 \mathrm{~h}$. Após a transferência, a membrana foi seca a $80^{\circ} \mathrm{C}$ por 30 min e o DNA fixado com tratamento de UV calibrado a $70.000 \mu \mathrm{J} \mathrm{cm}^{-2}$ de membrana, usando o programa padrão do forno de ultra-violeta Hoffer UVC 500 (Amersham). A membrana foi mergulhada em 2X SSC e submetida a pré-hibridização.

Para marcação da sonda, 50 ng de DNA previamente purificado foi desnaturado a $100^{\circ} \mathrm{C}$ por $5 \mathrm{~min}$, e colocado em gelo por $5 \mathrm{~min}$. Após centrifugar brevemente o microtubo, seu conteúdo foi adicionado no tubo de reação do kit Rediprime II (Amersham Biosciences), que recebeu a aplicação de 2 a $4 \mu \mathrm{L}$ de Redivue (20 a $40 \mu \mathrm{Ci},{ }^{32} \mathrm{P}$ dCTP, Amersham Biosciences), misturado por pipetagem repetida. A reação de incorporação do $\mathrm{dCTP}$ foi incubada à $37^{\circ} \mathrm{C}$ por $30 \mathrm{~min}$. Após a incubação, o tubo foi centrifugado rapidamente e recebeu $5 \mu \mathrm{L}$ de 0,2 M EDTA para cessar a reação. Uma amostra de $2 \mu \mathrm{L}$ da sonda marcada foi analisada para determinação da atividade do ${ }^{32} \mathrm{P}$. Em seguida, a sonda marcada foi purificada em uma microcoluna ProbeQuant G50 (Amersham Biosciences) para eliminação dos nucleotídeos não incorporados. Após a purificação, a sonda foi desnaturada a $100^{\circ} \mathrm{C}$ por $5 \mathrm{~min}$, e colocada no gelo por $5 \mathrm{~min}$.

A pré-hibridização da membrana foi feita em tampão $\left(25 \mathrm{mM} \mathrm{KPO}_{4}, \mathrm{pH}\right.$ 7,4; 5X SSC; 1\% SDS; 5X Solução de Denhardt; 50\% formamida deionizada; $67 \mu \mathrm{g}$ $\mathrm{mL}^{-1}$ de ssDNA de esperma de salmão) a $42^{\circ} \mathrm{C}$ por pelo menos de $2 \mathrm{~h}$. O tampão de hibridização utilizado é igual ao de pré-hibridização acrescido de $10 \%$ sulfato de dextran e de $45 \mu \mathrm{L}$ da sonda marcada purificada. O tempo de hibridização foi de $18 \mathrm{~h}$. 
A membrana era lavada duas vezes em tampão primário (2X SSC $+0,1 \%$ SDS) durante 5 min e 10 min a temperatura ambiente, seguida de lavagens com tampão secundário (1X SSC + 0,1\% SDS) por 10 min a temperatura ambiente, e em tampão terciário $(0,1 \mathrm{XSSC}+0,1 \% \mathrm{SDS})$ de uma até três vezes. A primeira lavagem com o tampão terciário foi feita a temperatura ambiente e as seguinte a $42^{\circ} \mathrm{C}$, durante $5-20 \mathrm{~min}$, dependendo da radioatividade detectada pelo radiômetro.

Após as lavagens, a membrana foi selada em plástico e exposta em cassete com filme permanente (Image Plate, Kodak, Japão), por tempo de exposição, em função do sinal detectado (cpm), variando de 3 horas até 2 dias. As imagens geradas foram obtidas com scanner Storm ${ }^{\circledR} 860$ Gel (Molecular Dynamics, Amersham Biosciences).

Para a re-utilização das membranas, a sonda era retirada tratando a membrana com solução fervente de $0,1 \%$ SDS, deixando que esta atingisse a temperatura ambiente (15-30 min). A membrana era imersa rapidamente em 2X SSC e a remoção da radioatividade era determinada com o uso de contador Geiger. A adição do $0,1 \%$ SDS fervente era repetida até que o sinal radioativo gerado fosse insignificante (< $100 \mathrm{cpm})$.

\subsection{Extração de RNA total}

Todas as soluções utilizadas na manipulação do RNA foram preparadas com água acrescida de DEPC 0,01\% (dietil pirocarbonato, Amersham Biosciences) 
dissolvido a temperatura ambiente sob agitação por pelo menos $4 \mathrm{~h}$, e autoclavada $\left(120^{\circ} \mathrm{C}, 20 \mathrm{~min}\right)$. Os cadinhos para moagem do material foram lavados em solução $0,1 \%$ SDS, enxaguados em água corrente, água destilada, água MilliQ e incubados em solução $0,01 \%$ DEPC ativo (sem autoclavar) por $2 \mathrm{hs}$. Em seguida, foram embalados em papel alumínio, autoclavados $\left(120^{\circ} \mathrm{C}, 20 \mathrm{~min}\right)$ e secos em estufa a $80^{\circ} \mathrm{C}$.

As extrações de RNA total foram feitas seguindo as recomendações básicas do reagente TRIzol ${ }^{\circledR}$ (Invitrogen), partindo de cerca de $350 \mathrm{mg}$ de tecido fresco pulverizado em cadinhos, na presença de $\mathrm{N}$ líquido. $\mathrm{O}$ macerado foi transferido para microtubo, e acrescido de $1,2 \mathrm{~mL}$ de TRIzol ${ }^{\circledR}$. O extrato foi homogeneizado e incubado por 5 min a temperatura ambiente, seguido de centrifugação a $10.000 \mathrm{~g}$ por $15 \mathrm{~min}$ a $4^{\circ} \mathrm{C}$. A fase aquosa foi transferida para um tubo novo, onde foram acrescido $240 \mu \mathrm{L}$ de clorofórmio, que foi emulsificado sob agitação, seguido de incubação a temperatura ambiente por 5 min. A emulsão foi então centrifugada $\left(10.000 \mathrm{~g}, 15 \min\right.$ a $\left.4^{\circ} \mathrm{C}\right)$, e a fase aquosa foi transferida novamente para um microtubo novo e o RNA foi precipitado com isopropanol $(600 \mu \mathrm{L})$ por 10 min a temperatura ambiente. O RNA precipitado foi centrifugado $\left(10.000 \mathrm{~g}, 10 \mathrm{~min}\right.$ a $\left.4^{\circ} \mathrm{C}\right)$ e o pellet foi lavado com etanol $75 \%$. Depois de seco (temperatura ambiente por $15 \mathrm{~min}$ ), o RNA foi ressuspenso em $30 \mu \mathrm{L}$ de água0.01\% DEPC. Os estoques de RNA foram mantidos a $-80^{\circ} \mathrm{C}$. O diagnóstico da qualidade das amostras foi feito em gel 1\% agarose em TAE. A quantificação das amostras de RNA foi realizado com espectrofotômetro SmartSpec 3000 (BioRad, Hercules, CA, EUA). 


\subsubsection{Análise de expressão por northern blot}

As amostras de RNA total (cerca $5 \mu \mathrm{g}$ ) foram preparadas em tampão de amostra [50\% de formamida; 1X MOPS (20 mM MOPS, $\mathrm{pH}$ 7,0; $50 \mathrm{mM}$ acetato de sódio; $1 \mathrm{mM}$ EDTA); $17,5 \%$ formaldeído; $0,4 \mathrm{mg} \mathrm{mL}^{-1}$ brometo de etídeo, e $10 \mathrm{X}$ loading buffer (0,25\% azul bromofenol; 0,25 \% xileno cianol; 0,1 mM EDTA, $\mathrm{pH} 8$; $50 \%$ glicerol)] e aquecidas a $55^{\circ} \mathrm{C}$ por $15 \mathrm{~min}$, seguido de $5 \mathrm{~min}$ no gelo antes de serem carregadas em gel. O RNA foi separado eletroforeticamente em gel desnaturante de 1,2 $\%$ agarose em $1 \mathrm{X}$ MOPS contendo $5 \%$ formaldeído, durante $40 \mathrm{~min}$ a $4 \mathrm{~V} \mathrm{~cm}^{-1}$. Após a corrida, o gel foi lavado em água mQ 0,01\% DEPC estéril por 20 min e incubado em 10X SSC por 40 min, em mesa agitadora. O RNA total foi transferido do gel para membrana de nylon XL Hybond (Amersham Biosciences) por capilaridade utilizando 10X SSC como tampão por $15 \mathrm{~h}$. Em seguida, a membrana foi seca a $80^{\circ} \mathrm{C}$ por $2 \mathrm{~h}$.

Para preparação da sonda radiomarcada, foram utilizados $50 \mathrm{ng}$ de cada fragmento amplificado e purificado (clone EST) conforme descrito anteriormente. A pré-hibridização durou pelo menos $2 \mathrm{~h} \mathrm{a} 42^{\circ} \mathrm{C}$, em solução contendo $50 \%$ de formamida deionizada; 5X SSC; 25 mM de fosfato de potássio pH 7,4; 5X solução de Denhardt; 1\% SDS; e $67 \mu \mathrm{g} \mathrm{mL}^{-1}$ de DNA de esperma de salmão. A sonda marcada foi desnaturada e adicionada $(45 \mu \mathrm{L})$ ao tampão de hibridização pré -aquecido $\left(42^{\circ} \mathrm{C}\right)$ igual ao de préhibridização acrescido de $10 \%$ sulfato de dextran. A hibridização a $42^{\circ} \mathrm{C}$ transcorreu por $18 \mathrm{~h}$. No fim da hibridização, a membrana foi lavada em tampão primário (2X SSC $+0,1 \%$ SDS) por 15 min a temperatura ambiente. Em seguida, a membrana foi lavada 
em tampão secundário $(0,25 \mathrm{X} \mathrm{SSC}+0,1 \% \mathrm{SDS})$, durante $15-20 \mathrm{~min}$ a temperatura ambiente, dependendo da radioatividade detectada. O tempo/número de lavagens foi determinado em função da diminuição da atividade relativa ao ${ }^{32} \mathrm{P}$ monitorada com contador Geiger. A membrana era então exposta em cassete a filme permanente (Image Plate, Kodak, Japão), em função do sinal detectado (cpm), e a exposição pode ser de 24 h até dias. As imagens de Northern geradas foram obtidas com scanner Storm ${ }^{\circledR} 860$ Gel (Molecular Dynamics, Amersham Biosciences).

\subsection{Análises estatísticas}

Os tratamentos do cada ensaio com metal foram dispostos de forma fatorial $5 \times 2$, com três repetições, em delineamento inteiramente casualizado. Os dados de taxa de crescimento e concentração de metais $(\mathrm{Cu}++$ e $\mathrm{Cd}++)$ em parte aérea e raiz foram submetidos a análises de variância e teste de Tukey, a 5\% de probabilidade na comparação das médias, utilizando o programa SAS System for windows V8. 


\section{RESULTADOS E DISCUSSÃO}

\subsection{Cultivo de plântulas de cana-de-açúcar em concentrações crescentes de Cu e Cd}

Foi conduzido um ensaio com plântulas de cana-de-açúcar crescidas em 4 concentrações crescentes de $\mathrm{Cu}(50,100,250$ e $500 \mu \mathrm{M})$ e três de $\mathrm{Cd}(100,250$ e 500 $\mu \mathrm{M})$ junto com os devidos controles, por um período de 33 dias, com uma avaliação intermediária aos 11 dias após a imposição dos tratamentos. Cada concentração de Cu e Cd era representada por 3 vasos com 4 plantas cada um. Foram amostradas 2 plantas de cada vaso aos 11 dias, e duas aos 33 dias, que foram divididas em parte aérea (folha + colmo) e raiz, avaliando o peso fresco.

\subsubsection{Efeito do cobre no crescimento e teor de metal nos tecidos}

Todas as dosagens de cobre testadas afetaram significativamente o peso fresco das plântulas de cana-de-açúcar avaliados aos 11 dias (Figura 2; Tabela 1 e Tabelas 2, 3 e 4). Entretanto, as menores dosagens de cobre (50 e $100 \mu \mathrm{M})$ causaram uma significativa, mas pequena inibição, no crescimento das plântulas (Figura 2; Tabela 1). Já a diferença em peso médio das plântulas não foi significativa entre essas dosagens 
de $\mathrm{Cu}(50$ e $100 \mu \mathrm{M})$ e o controle após 33 dias na presença do metal. Nas maiores dosagens $(250$ e $500 \mu \mathrm{M})$, as plântulas foram significativamente afetadas, com peso médio diferindo do controle, apresentando baixíssimo crescimento aos 11 dias, quando todas elas foram colhidas.

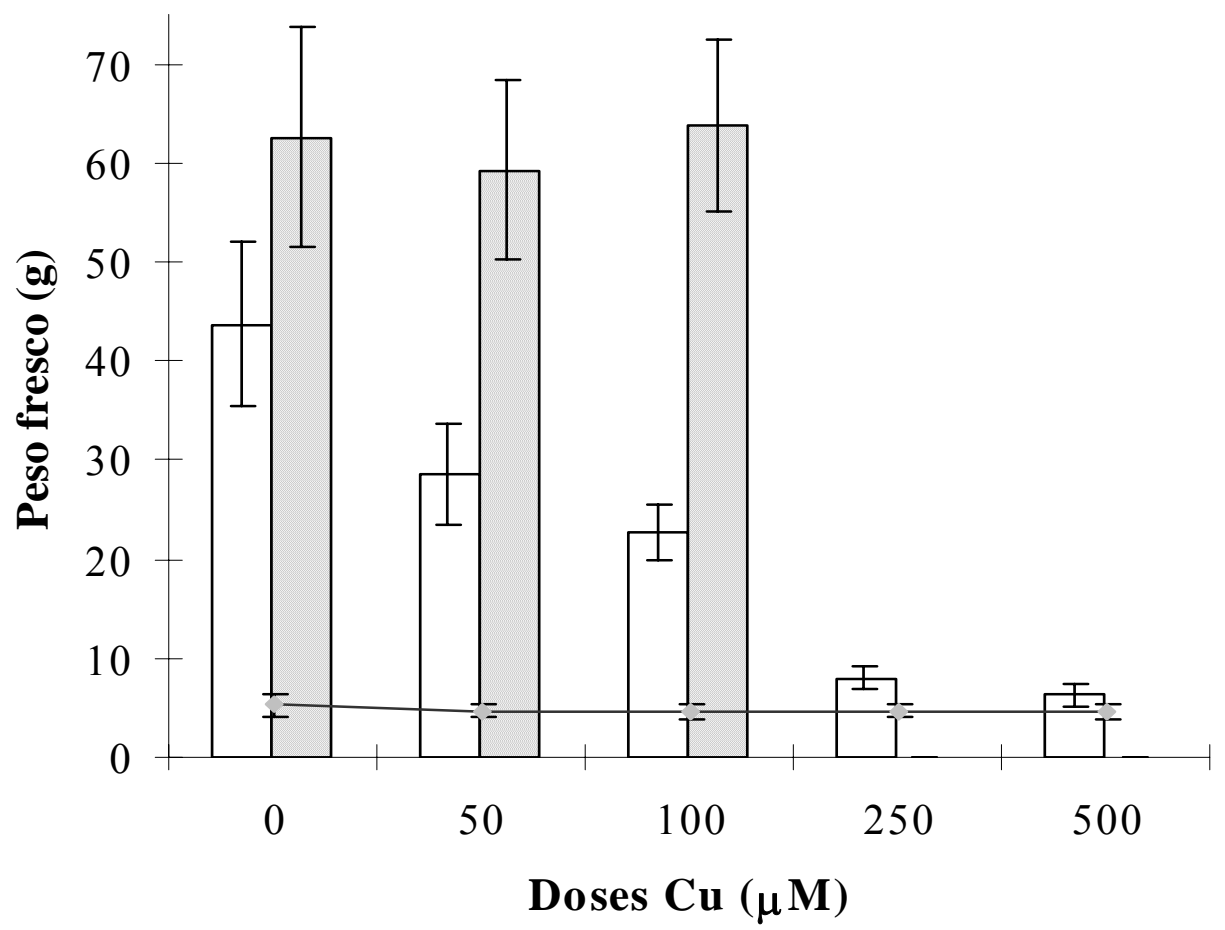

Figura 2 - Peso fresco médio final aos 11 dias (barras claras com desvio padrão) e 33 dias (barras escuras com desvio padrão) e inicial (pontos conectados por linha) das plantas de cana-de-açúcar cultivadas em solução nutritiva suplementada com concentrações crescentes de $\mathrm{Cu}(0 ; 50 ; 100 ; 250$; e 500 $\mu \mathrm{M}) . \mathrm{n}=6(2$ plantas $\mathrm{x} 3$ vasos $)$ 
Tabela 1. Valores médios ( \pm desvio padrão) de peso fresco $(\mathrm{g})$ e teores de $\mathrm{Cu}(\mathrm{ppm})$ em raízes e parte aérea das plântulas de cana-de-açúcar cultivadas em solução nutritiva em doses crescentes de $\mathrm{Cu}$ amostrados aos 11 e 33 dias. $\mathrm{DMS}=$ diferença mínima significativa pelo teste Tukey $(p=5 \%)$

\begin{tabular}{|c|c|c|c|c|c|c|}
\hline \multirow{3}{*}[\mathbf{Cu}]{$\mu \mathbf{M}$} & \multirow{2}{*}{\multicolumn{2}{|c|}{ Peso fresco (g) }} & \multicolumn{4}{|c|}{ [Cu] ppm } \\
\hline & & & \multicolumn{2}{|c|}{ Raiz } & \multicolumn{2}{|c|}{ Parte aérea } \\
\hline & 11 dias & 33 dias & 11 dias & 33 dias & 11 dias & 33 dias \\
\hline 0 & $42 \pm 18$ & $63 \pm 22$ & $8 \pm 1$ & $8 \pm 1$ & $7 \pm 0$ & $7 \pm 1$ \\
\hline 50 & $29 \pm 10$ & $59 \pm 18$ & $464 \pm 56$ & $239 \pm 52$ & $15 \pm 2$ & $26 \pm 2$ \\
\hline 100 & $23 \pm 6$ & $64 \pm 17$ & $553 \pm 22$ & $399 \pm 55$ & $31 \pm 6$ & $45 \pm 4$ \\
\hline 250 & $8 \pm 2$ & -- & $1961 \pm 631$ & -- & $192 \pm 57$ & -- \\
\hline 500 & $6 \pm 2$ & -- & $6465 \pm 1578$ & -- & $389 \pm 112$ & -- \\
\hline DMS & 15 & 31 & 1073 & 88 & 167 & 8 \\
\hline
\end{tabular}


Tabela 2. Análise de variância (The SAS System - The GLM Procedure) dos dados provenientes de taxas de crescimento de plântulas de cana-de-açúcar sob efeito de dose crescente de cobre

\begin{tabular}{lcccc}
\hline FV & GL & QM & F & Pr $>\mathbf{F}$ \\
\hline Repetição & 2 & 12,25333 & 0,35 & Ns \\
Tratamento & 14 & 1516,47519 & 42,90 & $* *$ \\
$\quad$ Dose & 4 & 317,34777 & 8,98 & $* *$ \\
$\quad$ Tempo & 2 & 6818,27326 & 192,87 & $* *$ \\
$\quad$ Dose * Tempo & 6 & 238,15252 & 6,74 & $* *$ \\
Resíduo & 24 & 35,35236 & & \\
Total & 38 & & & \\
Ns = não significativo; *5\% significância; **1\% significância; $\mathbf{C V}=24$ &
\end{tabular}

Tabela 3. Análise de variância (The SAS System - The GLM Procedure) dos dados provenientes de taxas de crescimento de plântulas de cana-de-açúcar sob efeito de dose crescente de cobre com desdobramento do fator tempo

\begin{tabular}{lcccc}
\hline FV & GL & QM & F & Pr $>$ F \\
\hline 0 dias & 4 & 0,141000 & 0,0 & Ns \\
11 dias & 4 & 666,199583 & 18,84 & $* *$ \\
33 dias & 2 & 16,471944 & 0,47 & Ns \\
\hline
\end{tabular}

Tabela 4. Análise de variância (The SAS System - The GLM Procedure) dos dados provenientes de taxas de crescimento de plântulas de cana-de-açúcar sob efeito de dose crescente de cobre com desdobramento do fator dose

\begin{tabular}{ccccc}
\hline FV & GL & QM & F & Pr $>$ F \\
\hline $0 \mu \mathrm{M}$ & 2 & 2538,791944 & 71,81 & $* *$ \\
$50 \mu \mathrm{M}$ & 2 & 2241,860278 & 63,41 & $* *$ \\
$100 \mu \mathrm{M}$ & 2 & 2742,234444 & 77,57 & $* *$ \\
$250 \mu \mathrm{M}$ & 1 & 16,006667 & 0,45 & $\mathrm{Ns}$ \\
$500 \mu \mathrm{M}$ & 1 & 3,681667 & 0,10 & Ns \\
\hline
\end{tabular}


Em termos de sintomas visuais de intoxicação, pela presença de $\mathrm{Cu}$, as plântulas crescidas nas menores dosagens (50 e $100 \mu \mathrm{M})$ não apresentaram alterações morfológicas visíveis aos 11 dias (Figura 3), nem aos 33 dias (Figura 4), exceto pela aparente redução no tamanho do sistema radicular na concentração de $100 \mu \mathrm{M}$ (Figura 3

e 4). Em relação as dosagens de 250 e $500 \mu \mathrm{M}$, as plantas começaram a apresentar sintomas de intoxicação por $\mathrm{Cu}$ aos 8 dias de tratamento, mostrando pontos de oxidação (regiões mais escuras) e engrossamento, sendo que aos 11 dias foi necessário coletar todas elas, devido a iminência da morte dos indivíduos (Figura 3).
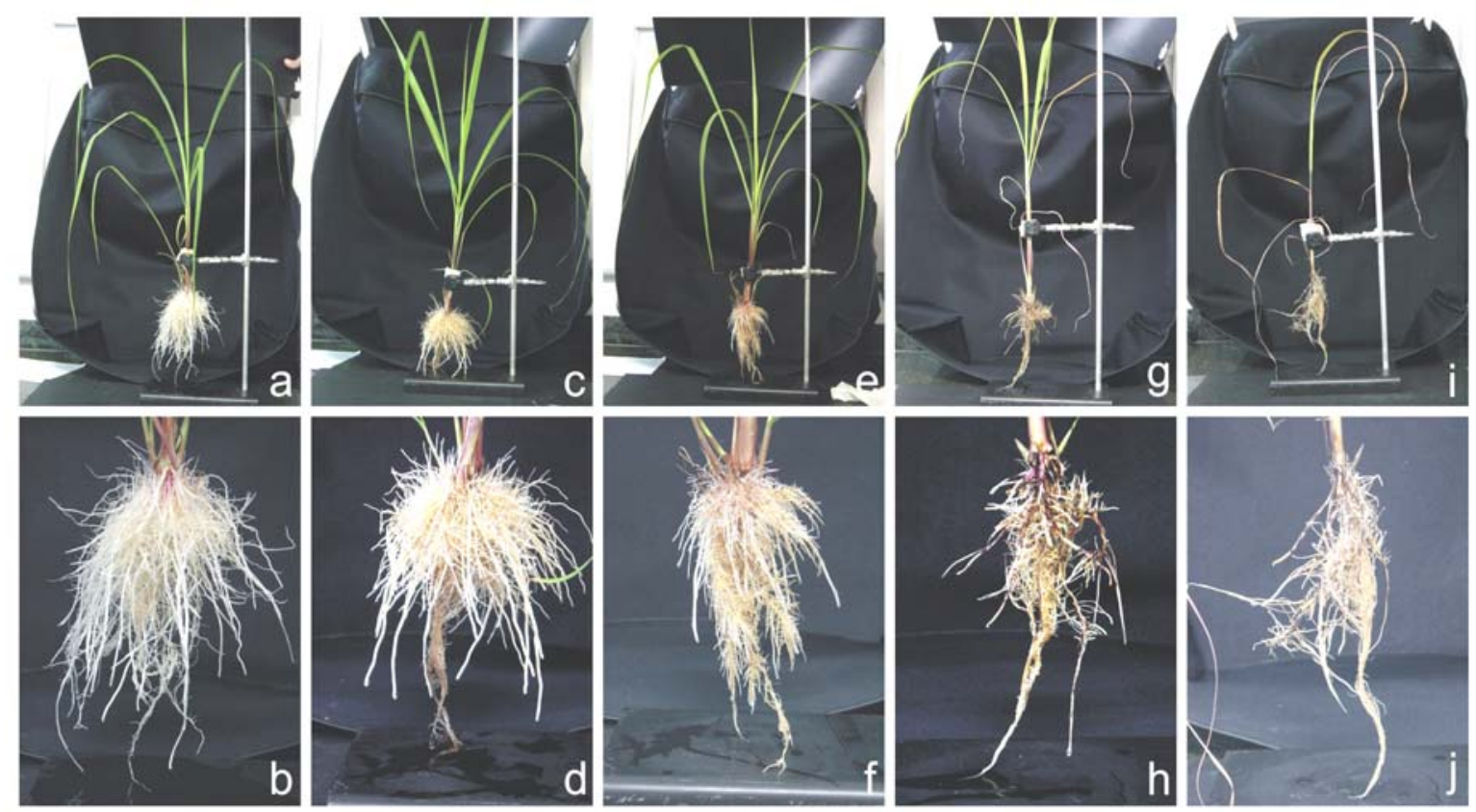

Figura 3 - Aspecto das plântulas de cana-de-açúcar e suas raízes após 11 dias de cultivo em solução nutritiva contendo doses crescentes de cobre: $\mathrm{a}-\mathrm{b}=$ controle $(0$ $\mu \mathrm{M}), \mathrm{c}-\mathrm{d}=50 \mu \mathrm{M} ; \mathrm{e}-\mathrm{f}=100 \mu \mathrm{M}, \mathrm{g}-\mathrm{h}=250 \mu \mathrm{M}, \mathrm{i}-\mathrm{j}=500 \mu \mathrm{M}$ 

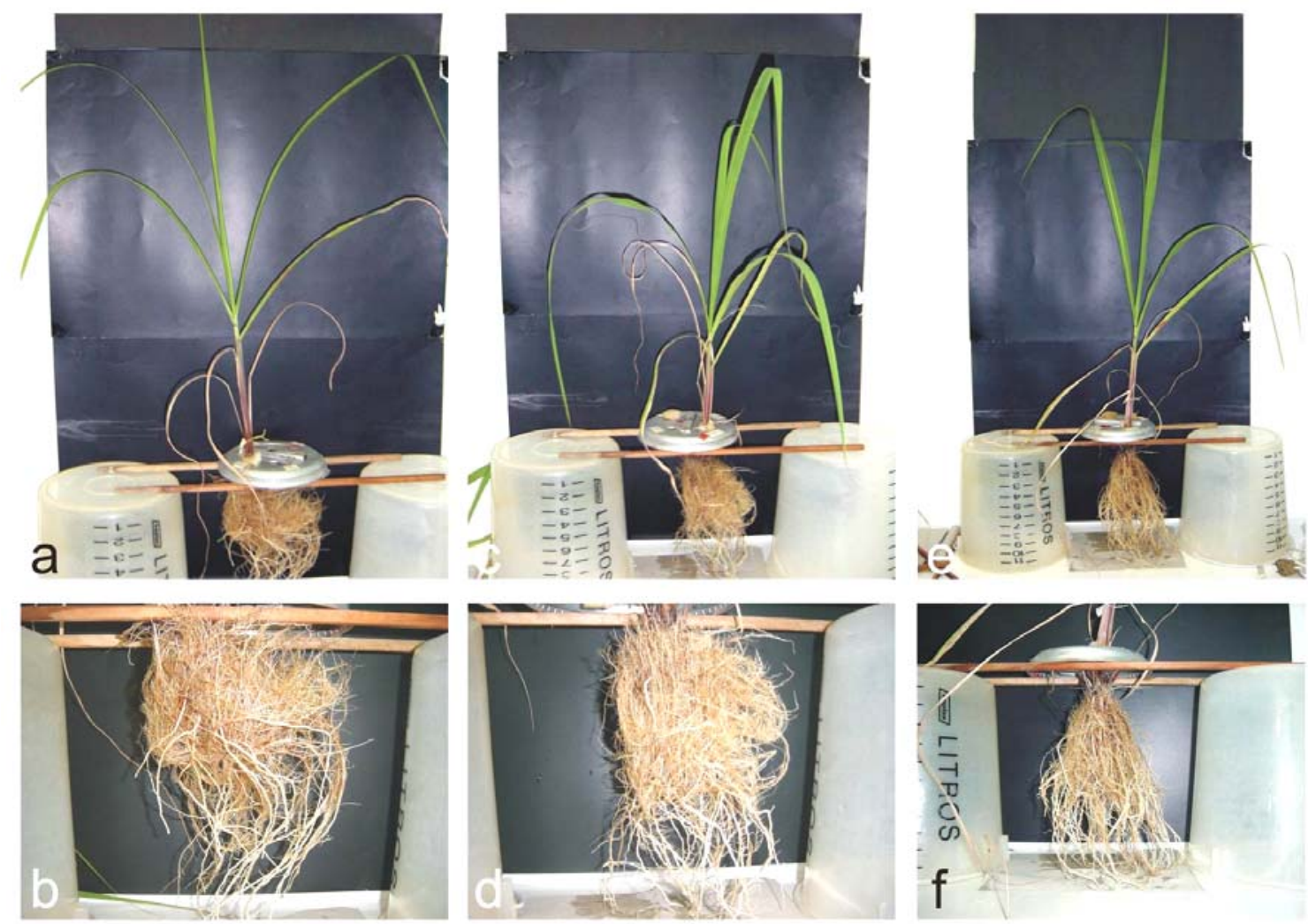

Figura 4 - Aspecto das plântulas de cana-de-açúcar e suas raízes após 33 dias de cultivo em solução nutritiva contendo doses crescentes de cobre: $\mathrm{a}-\mathrm{b}=$ controle $(0$ $\mu \mathrm{M}), \mathrm{c}-\mathrm{d}=50 \mu \mathrm{M} ; \mathrm{e}-\mathrm{f}=100 \mu \mathrm{M}$ 
Em relação ao acúmulo de $\mathrm{Cu}$, houve diferenças significativas entre o teor de Cu na parte aérea (Figura 5 A e Figura 6; Tabela 1 e Tabelas 5, 6 e 7) e raízes (Figura 5 B e Figura 6; Tabela 1 e Tabelas 8, 9 e 10) nas dosagens crescentes do metal. Os teores de $\mathrm{Cu}$ nas raízes e parte aérea das plântulas do controle foram similares, inclusive entre os dois tempos de coleta (11 e 33 dias), mas nos tratamentos de doses crescentes de $\mathrm{Cu}$, as raízes exibiram uma concentração muito maior do metal que a parte aérea (de 10 a 20 vezes maior) [Tabela 1].

Os teores de $\mathrm{Cu}$ detectados em raízes para as dosagens de 50 e $100 \mu \mathrm{M}$ aos 11 dias foram superiores àqueles detectados aos 33 dias, mas não para os teores da parte aérea, onde observaram-se valores maiores aos 33 dias (Tabela 1). Entretanto se observamos esses mesmos valores considerando-os em termos de valores absolutos [(ppm x peso fresco)/1000] o acúmulo nas raízes na dose de $100 \mu \mathrm{M}$ é o dobro aos 33 dias com relação aos 11 dias. Para a dose de $50 \mu \mathrm{M}$ não houve diferenças significativas entre ambos os tempos avaliados. Com relação à parte aérea, os valores absolutos obtidos para os 33 dias foram três e quatro vezes maiores que os mesmos valores para as dose de 50 e $100 \mu \mathrm{M}$ aos 11 dias, respectivamente. Houve diferença significativa nos teores de cobre na parte aérea para todas as dosagens testadas em relação ao controle, indicando ter havido absorção e translocação de $\mathrm{Cu}$, e o conseqüente acúmulo nestes tecidos. O fato da plantas crescidas nas doses de 50 e $100 \mu \mathrm{M}$ aos 33 dias não apresentarem peso fresco médio diferente das plantas controles, somado ao fato dos teores de cobre em valores absolutos nas raízes serem proporcionalmente baixos neste tempo, (principalmente para a dose de $50 \mu \mathrm{M}$ ) poderia significar, que após um tempo 
prolongado de exposição ao metal, as plantas encontraram uma saída para superar os efeitos tóxicos, precipitando o cobre na superfície celular das raízes evitando a absorção, mecanismo este de tolerância comum entre as culturas (Reeves, et al, 1995). No entanto, os valores absolutos dos teores de cobre na parte aérea das plantas nas mesmas doses aos 33 dias foram muito superiores ( $\cong 3$ e 4 vezes maiores) indicando que houve absorção, translocação e acúmulo do metal nestes tecidos.

Nas dosagens de 250 e $500 \mu \mathrm{M}$ de cobre aos 11 dias, as quantidades acumuladas deste metal foram significativamente maiores que os demais tratamentos, tanto na parte aérea quanto nas raízes (Figura 5 A e B), tendo sido possivelmente a causa da morte das plântulas nessas dosagens. 


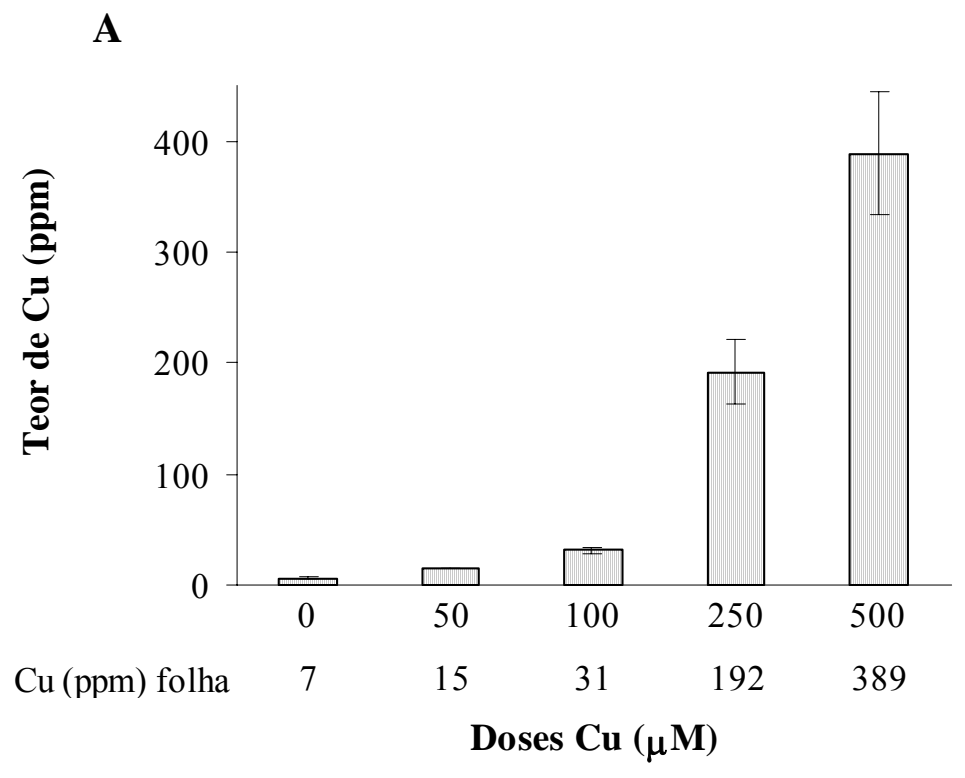

B

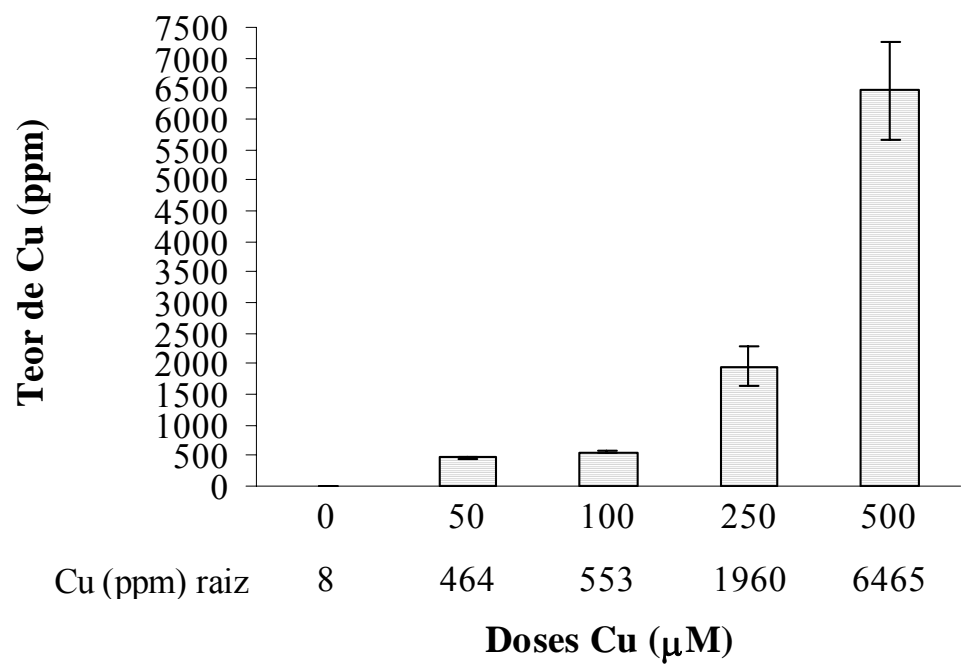

Figura 5 - Concentração média de cobre (barra \pm desvio padrão) da parte aérea (A) e raízes (B) de plântulas de cana-de-açúcar após 11 dias de cultivo em solução nutritiva suplementada com concentrações crescentes de $\mathrm{Cu}(0 ; 50$; $100 ; 250$; e $500 \mu \mathrm{M}) . \mathrm{n}=6(2$ plantas $\times 3$ vasos $)$ 


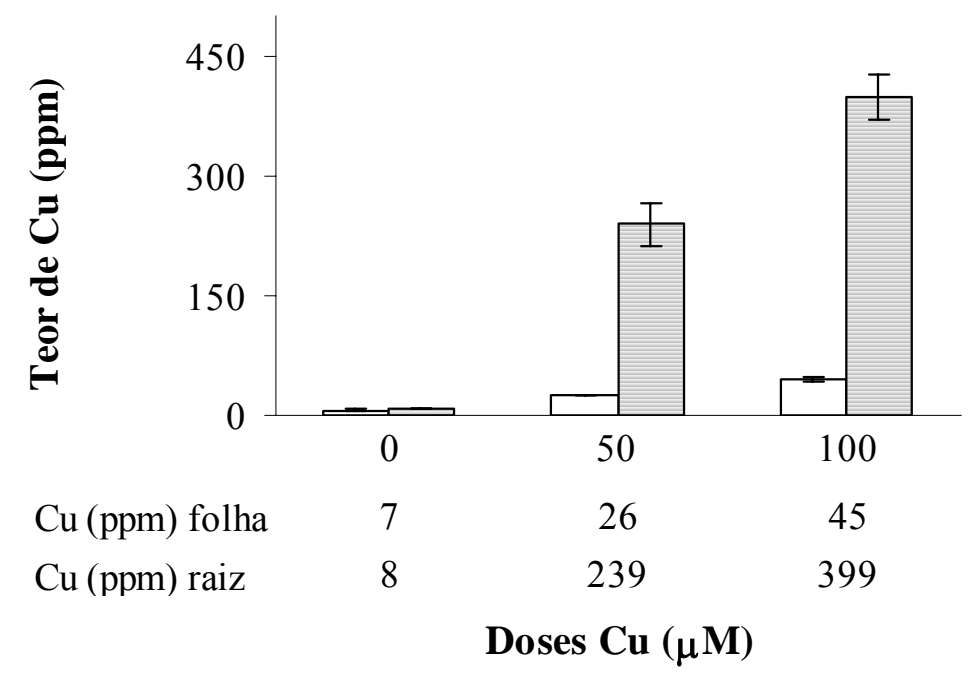

Figura 6 - Concentração média de cobre em parte aérea (barras claras com desvio padrão) e raízes (barras escuras com desvio padrão) de plântulas de cana-deaçúcar após 33 dias de cultivo em solução nutritiva suplementada com concentrações crescentes de $\mathrm{Cu}(0 ; 50$ e $100 \mu \mathrm{M}) . \mathrm{n}=6$ (2 plantas x 3 vasos $)$ 
Tabela 5. Análise de variância (The SAS System - The GLM Procedure) dos dados provenientes dos teores de cobre na parte aérea de plântulas de cana-deaçúcar

\begin{tabular}{lcccc}
\hline FV & GL & $\mathbf{Q M}$ & $\mathbf{F}$ & Pr $>\mathbf{F}$ \\
\hline Repetição & 2 & 1556,3170 & 1,15 & $\mathrm{Ns}$ \\
Tratamento & 14 & 33038,7348 & 24,51 & $* *$ \\
$\quad$ Dose & 4 & 41244,1071 & 30,60 & $* *$ \\
$\quad$ Tempo & 2 & 61090,7066 & 45,32 & $* *$ \\
$\quad$ Dose * Tempo & 6 & 27356,8998 & 20,29 & $* *$ \\
Resíduo & 24 & 1347,9955 & & \\
Total & 38 & & & \\
\hline Ns = não significativo* *5\% significância;**1\% significância; $\mathbf{C V}=67$ &
\end{tabular}

Ns = não significativo; *5\% significância; **1\% significância; $\mathbf{C V}=67$

Tabela 6. Análise de variância (The SAS System - The GLM Procedure) dos dados provenientes dos teores de cobre na parte aérea de plântulas de cana-deaçúcar com desdobramento do fator tempo

\begin{tabular}{lcccc}
\hline FV & GL & QM & F & Pr $>$ F \\
\hline 0 dias & 4 & $1,308626 \mathrm{E}-25$ & 0,0 & Ns \\
11 dias & 4 & 81740 & 60,64 & $* *$ \\
33 dias & 2 & 1079,830811 & 0,80 & Ns \\
\hline
\end{tabular}

Tabela 7. Análise de variância (The SAS System - The GLM Procedure) dos dados provenientes dos teores de cobre na parte aérea de plântulas de cana-deaçúcar do fator dose

\begin{tabular}{lcccc}
\hline FV & GL & QM & F & Pr $>$ F \\
\hline $0 \mu \mathrm{M}$ & 2 & 44,461900 & 0,03 & Ns \\
$50 \mu \mathrm{M}$ & 2 & 493,679078 & 0,37 & Ns \\
$100 \mu \mathrm{M}$ & 2 & 1576,490878 & 1,17 & Ns \\
$250 \mu \mathrm{M}$ & 1 & 55392 & 41,09 & $* *$ \\
$500 \mu \mathrm{M}$ & 1 & 226702 & 168,18 & $* *$ \\
\hline
\end{tabular}


Tabela 8. Análise de variância (The SAS System - The GLM Procedure) dos dados provenientes dos teores de cobre nas raízes de plântulas de cana-de-açúcar

\begin{tabular}{lcccc}
\hline FV & GL & QM & F & Pr > F \\
\hline Repetição & 2 & 110112,18 & 1,65 & Ns \\
Tramento & 14 & 8271894,5 & 124,24 & $* *$ \\
$\quad$ Dose & 4 & 10665134,24 & 160,19 & $* *$ \\
$\quad$ Tempo & 2 & 13394066,95 & 201,18 & $* *$ \\
$\quad$ Dose * Tempo & 6 & 7077586,82 & 106,31 & $* *$ \\
Resíduo & 24 & 66577,3 & & \\
Total & 38 & & & \\
Ns = não significativo; *5\% significância; **1\% significância; $\mathbf{C V}=33$ &
\end{tabular}

Tabela 9. Análise de variância (The SAS System - The GLM Procedure) dos dados provenientes dos teores de cobre nas raízes de plântulas de cana-de-açúcar com desdobramento do fator tempo

\begin{tabular}{lcccc}
\hline FV & GL & QM & F & Pr $>$ F \\
\hline 0 dias & 4 & $3,424528 \mathrm{E}-23$ & 0,0 & Ns \\
11 dias & 4 & 21223691 & 318,78 & $* *$ \\
33 dias & 2 & 115646 & 1,74 & Ns \\
\hline
\end{tabular}

Tabela 10. Análise de variância (The SAS System - The GLM Procedure) dos dados provenientes dos teores de cobre nas raízes de plântulas de cana-de-açúcar com desdobramento do fator dose

\begin{tabular}{lcccc}
\hline FV & GL & QM & F & Pr $>$ F \\
\hline $0 \mu \mathrm{M}$ & 2 & 64.939144 & 0,0 & Ns \\
$50 \mu \mathrm{M}$ & 2 & 161477 & 2,43 & $\mathrm{Ns}$ \\
$100 \mu \mathrm{M}$ & 2 & 244048 & 3,67 & $*$ \\
$250 \mu \mathrm{M}$ & 1 & 5749882 & 86,36 & $* *$ \\
$500 \mu \mathrm{M}$ & 1 & 62692592 & 941,65 & $* *$ \\
\hline
\end{tabular}


O cobre é um elemento essencial para todos os organismos a baixas concentrações, mas é conhecido que níveis elevados de $\mathrm{Cu}$ exercem efeitos daninhos sobre o crescimento das plantas inibindo a fotossíntese e a captação de nutrientes minerais, inclusive em plantas tolerantes ao $\mathrm{Cu}$ (Shu et al, 2002). Em Elsholtzia haichowensis (Lamiaceae), uma planta que cresce em solos contaminados com cobre, foi relatado um crescimento normal das raízes numa faixa de concentrações de 10 a 100 $\mu \mathrm{M}$, mas a partir de $300 \mu \mathrm{M}$ a biomassa das raízes (matéria seca) foi reduzida significativamente, de forma diretamente proporcional ao aumento da concentração de cobre e o tempo de exposição ao metal (Lou, et al., 2004). No outro extremo, plantas de arroz apresentaram uma forte redução no comprimento das raízes a concentrações muito inferiores $(30-50 \mu \mathrm{M})$ deste metal, chegando a uma redução de até $79 \%$ na máxima dosagem (Chen et al, 2000). Embora houvesse redução do crescimento da parte aérea em arroz, a diferença não foi significativa entre cada tratamento e o controle. A dose de $30 \mu \mathrm{M}$ reduziu o crescimento (biomassa) radicular em $30 \%$, com relação as plantas controle (Chen et al, 2000). De forma similar, Ouzounidou et al., (1995) relataram para o milho uma inibição de $84 \%$ na produção de biomassa nas raízes de plantas crescidas em até $80 \mu \mathrm{M}$ de $\mathrm{Cu}$ em relação ao controle sem metal. Em todos os casos, as raízes apresentaram maiores concentrações de $\mathrm{Cu}$ que a parte aérea das plantas, sendo maior nas concentrações mais elevadas do metal em solução como relatado no presente trabalho. Em geral, as concentrações de $\mathrm{Cu}$ nas plantas com tolerância normal a metais foram de 5 a 20 ppm de matéria seca (Reeves et al, 1995). No entanto em algumas plantas hipertolerantes a metais, as concentrações de $\mathrm{Cu}$ podem ser muito altas como é o 
caso de Elsholtzia haichowensis, quem acumula até 20.200 ppm nas raízes tratadas crescidas em solução com $500 \mu \mathrm{M}$ de $\mathrm{Cu}$ (100 vezes mais que na parte aérea) (Lou, et al., 2004). O milho, uma planta considerada normal em termos de tolerância a metais, foi capaz de acumular $\underline{7.790}$ ppm de $\mathrm{Cu}$ nas raízes e translocar $\underline{40}$ ppm para parte aérea (Ouzounidou et al., 1995), quando crescido em $80 \mu \mathrm{M}$ de $\mathrm{Cu}$, entretanto sua biomassa decresceu em $84 \%$ após 15 dias de tratamento. Neste trabalho com cana-de-açúcar, para uma dose similar $(100 \mu \mathrm{M})$, obteve-se um acúmulo de $\mathrm{Cu}$ de $\underline{553}$ ppm nas raízes e $\underline{31}$ ppm na parte aérea, mas a inibição do crescimento foi de apenas $48 \%$. Se considerarmos a produtividade média da cana, maior que $120 \mathrm{t} \mathrm{ha}^{-1}$ (COPERSUCAR, 2004) versus a do milho, $20 \mathrm{t} \mathrm{h}^{-1}$, citado por Chaney et al (1999) num caso hipotético para seu uso em fitorremediação, espera-se que a planta de cana-de-açúcar seja capaz de extrair do solo $10 \mathrm{~kg}$ a mais $(40 \%)$ de $\mathrm{Cu}$ nas mesmas condições.

Portanto, é possível concluir que as plântulas de cana-de-açúcar apresentaram tolerância satisfatória até a dose de $100 \mu \mathrm{M}$ de $\mathrm{Cu}$ na solução nutritiva, pois apresentaram um crescimento não diferente do controle ou da dose de $50 \mu \mathrm{M}$ aos 33 dias após exposição ao $\mathrm{Cu}$, apesar de ter sido inibitório nos primeiros 11 dias. $\mathrm{Na}$ concentração de $100 \mu \mathrm{M}$ de $\mathrm{Cu}$, houve absorção e translocação do metal para a parte aérea, fundamental para a estratégia da fitorremediação (Figura 5 e 6). A tolerância de cana ao cobre relativa à porcentagem de inibição do crescimento, foi comparável à encontrada em Elsholtzia haichowensis, embora que para as menores doses e após 33 dias de tratamento, e bem superior à informada para seus parentes mais próximos, arroz e milho. 


\section{1. 2 Efeito do cádmio no crescimento e teor de metal nos tecidos}

Para o cultivo de plântulas de cana na presença de três doses crescentes de $\mathrm{Cd}$ $(100,250$ e $500 \mu \mathrm{M})$, se observou aos 11 dias, redução significativas no peso fresco final, entre as plântulas cultivadas na presença do metal em relação ao controle (Figura 7; Tabela 11 e Tabelas 12, 13 e 14). A mesma tendência se manteve para as plântulas coletadas aos 33 dias, agora com um maior efeito inibitório de crescimento (Figura 7; Tabela 11 e Tabelas 12, 13 e 14). As diferenças de crescimento foram proporcionais as doses de Cd presentes. Apesar de reduzir o crescimento das plântulas, o Cd não causou a morte destas como as maiores doses de cobre. É importante ressaltar que as plântulas mantiveram seu crescimento mesmo a $250 \mu \mathrm{M}$ de $\mathrm{Cd}$, indicando o potencial de tolerância da cana a esse metal. A maior tolerância de cana-de-açúcar ao Cd já havia sido observada por Fornazier et al., (2002) quando toletes de cana foram crescidos em hidroponia na concentração de até $5 \mathrm{mM}$ de $\mathrm{Cd}$. 


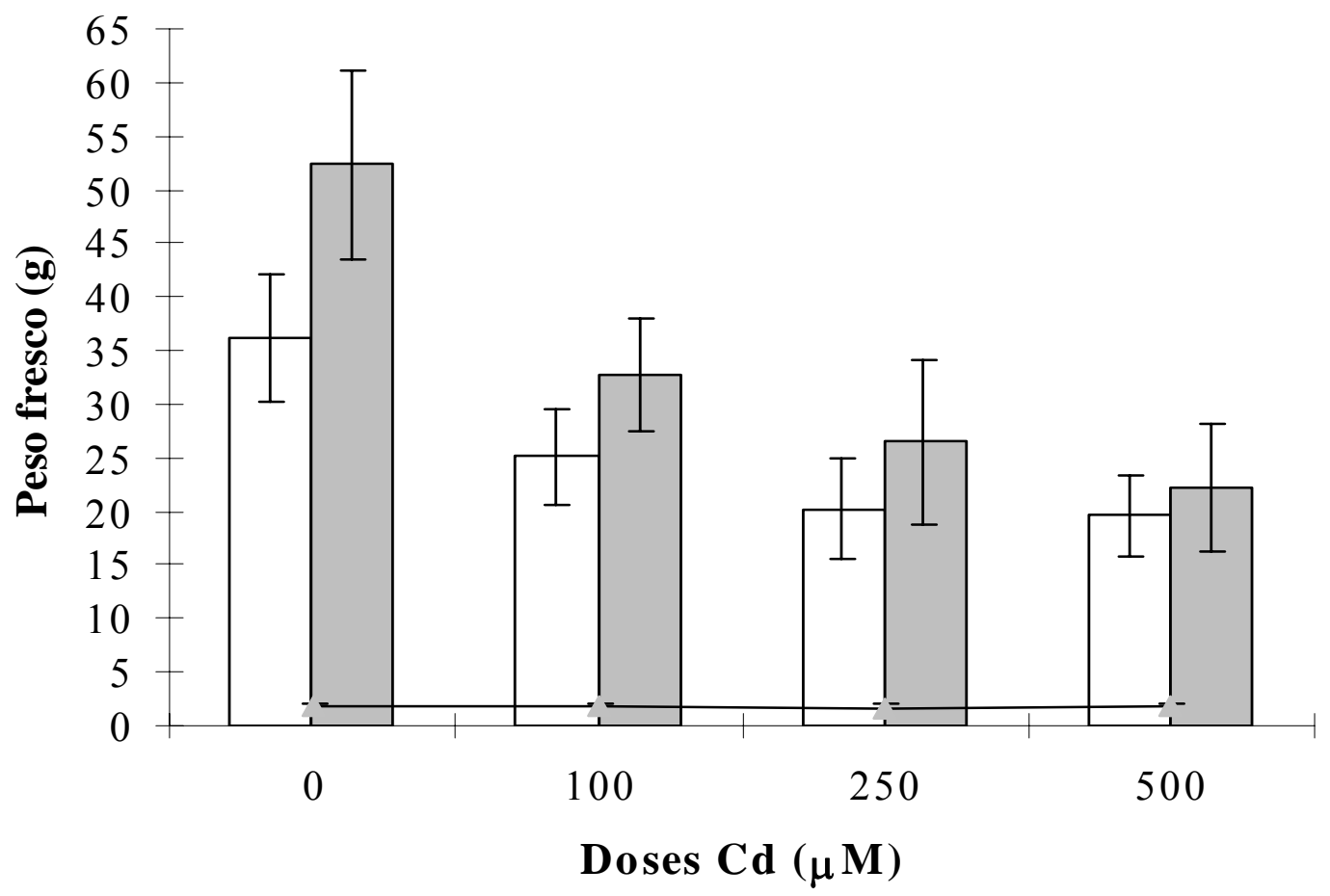

Figura 7 - Peso fresco médio final aos 11 dias (barras claras com desvio padrão) e 33 dias (barras escuras com desvio padrão) e inicial (pontos conectados por linha) das plantas de cana-de-açúcar cultivadas em solução nutritiva suplementada com concentrações crescentes de $\mathrm{Cd}(0 ; 100 ; 250$; e $500 \mu \mathrm{M})$. $\mathrm{n}=6(2$ plantas $\mathrm{x} 3$ vasos $)$ 
Tabela 11. Valores médios ( \pm desvio padrão) de peso fresco $(\mathrm{g})$ e teores de $\mathrm{Cd}(\mathrm{ppm})$ em raízes e parte aérea de plântulas de cana-de-açúcar cultivadas em solução nutritiva em doses crescentes de Cd amostrados aos 11 e 33 dias. DMS = diferença mínima significativa pelo teste Tukey $(p=5 \%)$

\begin{tabular}{ccccccc}
\hline & \multirow{2}{*}{ Peso fresco (g) } & \multicolumn{5}{c}{ [Cd] ppm } \\
\cline { 3 - 7 } [Cd] $\boldsymbol{\mu M}$ & & & \multicolumn{2}{c}{ Raiz } & \multicolumn{3}{c}{ Parte aérea } \\
& 11 dias & 33 dias & $\mathbf{1 1}$ dias & 33 dias & 11 dias & 33 dias \\
\hline 0 & $36 \pm 12$ & $52 \pm 18$ & $85 \pm 19$ & $118 \pm 75$ & $34 \pm 5$ & $24 \pm 2$ \\
100 & $25 \pm 9$ & $33 \pm 11$ & $2714 \pm 260$ & $2397 \pm 456$ & $218 \pm 85$ & $175 \pm 24$ \\
250 & $20 \pm 10$ & $27 \pm 15$ & $6362 \pm 1163$ & $5059 \pm 1616$ & $305 \pm 82$ & $254 \pm 77$ \\
500 & $20 \pm 8$ & $22 \pm 12$ & $10833 \pm 3421$ & $9621 \pm 1927$ & $368 \pm 88$ & $451 \pm 148$ \\
\hline DMS & 21 & 22 & 5248 & 4075 & 228 & 250 \\
\hline
\end{tabular}


Tabela 12. Análise de variância (The SAS System - The GLM Procedure) dos dados provenientes das taxas de crescimento de plântulas de cana-de-açúcar no experimento com cádmio

\begin{tabular}{lcccc}
\hline FV & GL & QM & F & Pr $>\mathbf{F}$ \\
\hline Repetição & 2 & 4,918219 & 0,13 & Ns \\
Tratamento & 13 & 662,064953 & 16,91 & $* *$ \\
$\quad$ Dose & 3 & 434,860844 & 11,11 & $* *$ \\
$\quad$ Tempo & 2 & 3242,015511 & 82,82 & $* *$ \\
$\quad$ Dose * Tempo & 6 & 134,732400 & 3,44 & $*$ \\
Resíduo & 22 & 39,143159 & & \\
Total & 35 & & & \\
Ns = não significativo; *5\% significância; **1\% significância; $\mathbf{C V = 3 1}$ &
\end{tabular}

Tabela 13. Análise de variância (The SAS System - The GLM Procedure) dos dados provenientes das taxas de crescimento de plântulas de cana-de-açúcar no experimento com cádmio com desdobramento do fator tempo

\begin{tabular}{lcccc}
\hline FV & GL & QM & F & Pr $>$ F \\
\hline 0 dias & 3 & 0,002222 & 0,0 & Ns \\
11 dias & 3 & 170,305644 & 4,35 & $*$ \\
33 dias & 3 & 534,017778 & 13,64 & $* *$ \\
\hline
\end{tabular}

Tabela 14 Análise de variância (The SAS System - The GLM Procedure) dos dados provenientes das taxas de crescimento de plântulas de cana-de-açúcar no experimento com cádmio com desdobramento do fator dose

\begin{tabular}{lcccc}
\hline $\mathbf{F V}$ & GL & QM & F & Pr $>\mathbf{F}$ \\
\hline $0 \mu \mathrm{M}$ & 2 & 1999,006044 & 51,07 & $* *$ \\
$100 \mu \mathrm{M}$ & 2 & 779,537778 & 19,92 & $* *$ \\
$250 \mu \mathrm{M}$ & 2 & 494,981111 & 12,65 & $* *$ \\
$500 \mu \mathrm{M}$ & 2 & 372,687778 & 9,52 & $* *$ \\
\hline
\end{tabular}


Em relação a sintomas visuais de intoxicação, foram detectados pontos de oxidação no sistema radicular e engrossamento anormais na presença de $\mathrm{Cd}$ aos 11 dias (Figura 8) e aos 33 dias (Figura 9) proporcional à concentração do metal. O crescimento radicular foi menos afetado pela presença do $\mathrm{Cd}$ em relação ao controle, do que aquele observado com o $\mathrm{Cu}$. Ao final do experimento (33 dias), as plantas expostas ao $\mathrm{Cd}$ apresentaram sintomas de toxidez por Cd (raízes escuras e folhas amareladas) e um menor desenvolvimento, sendo estes sintomas mais intensos nas maiores dosagens (Figura 9). Os sintomas de intoxicação observados foram mais brandos do que aqueles detectados para altas doses de cobre. 

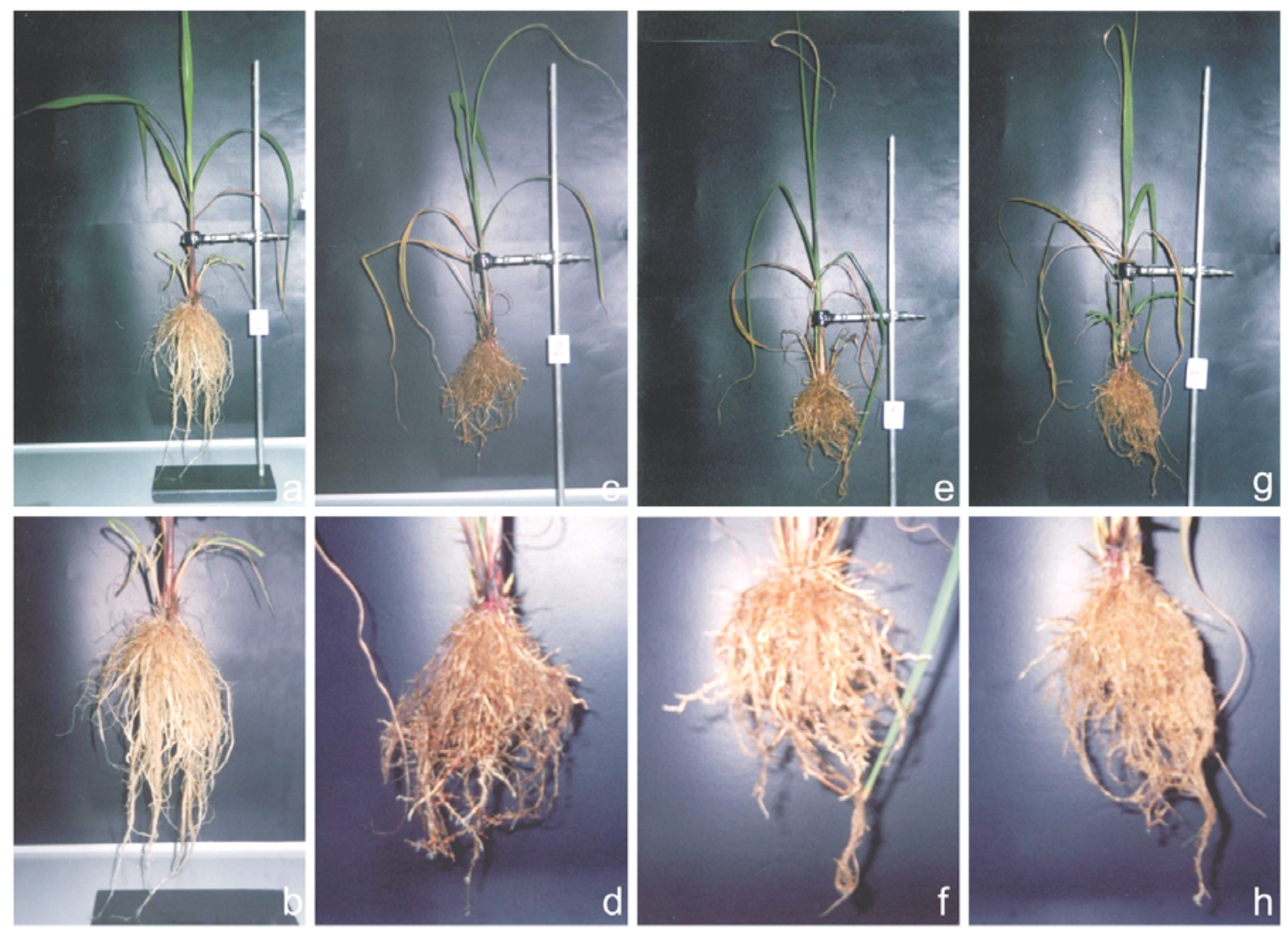

Figura 8 - Aspecto das plântulas de cana-de-açúcar e suas raízes após 11 dias de cultivo em solução nutritiva contendo doses crescentes de cádmio: $a-b=$ controle $(0 \mu \mathrm{M}), \mathrm{c}-\mathrm{d}=100 \mu \mathrm{M}$; e-f $=250 \mu \mathrm{M} ; \mathrm{g}-\mathrm{h}=500 \mu \mathrm{M}$ 

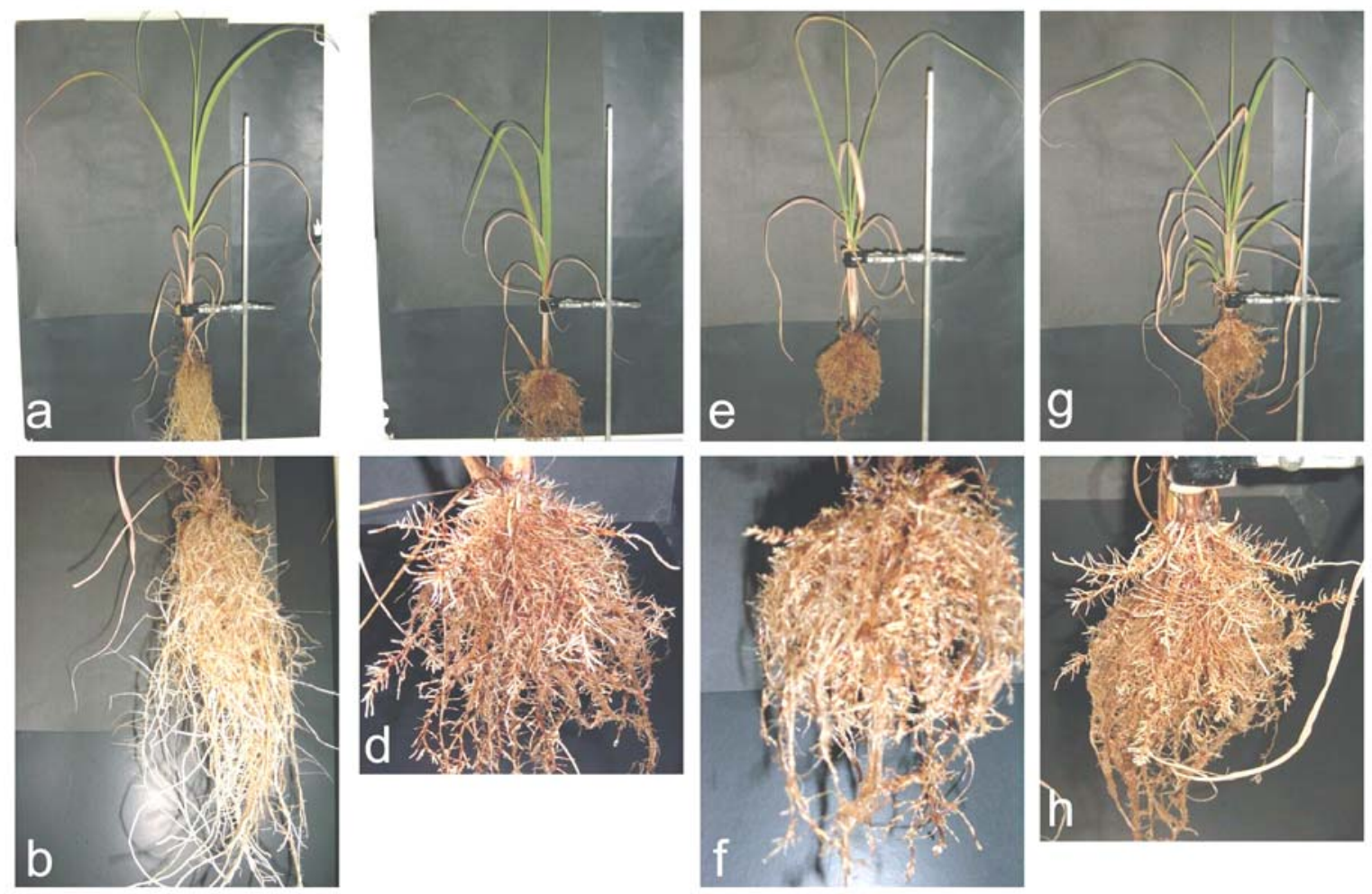

Figura 9 - Aspecto das plântulas de cana-de-açúcar e suas raízes após 33 dias de cultivo em solução nutritiva contendo doses crescentes de cádmio: $\mathrm{a}-\mathrm{b}=$ controle $(0$ $\mu \mathrm{M}), \mathrm{c}-\mathrm{d}=100 \mu \mathrm{M} ; \mathrm{e}-\mathrm{f}=250 \mu \mathrm{M} ; \mathrm{g}-\mathrm{h}=500 \mu \mathrm{M}$ 
Em relação aos teores de $\mathrm{Cd}$ detectados na parte aérea e raízes, houve um acúmulo significativo do metal nas raízes, proporcional a dosagem imposta, observado aos 11 dias e aos 33 dias (Tabela 11; Figura 10 e 11). As raízes e parte aérea das plântulas apresentaram valores significativamente elevados de $\mathrm{Cd}$ indicando que o metal foi absorvido e translocado, afetando proporcionalmente o crescimento das plântulas (Tabelas 15, 16 e 17 e Tabelas 18, 19 e 20). As concentrações de Cd nas raízes e folhas (com exceção dos valores encontrados para folhas na dose de $500 \mu \mathrm{M}$ ) aos 33 dias foram inferiores daqueles detectadas aos 11 dias. De forma similar ao descrito para $\mathrm{Cu}$, quando analisados os valores absolutos relativos ao peso fresco das plantas, observa-se um pequeno aumento da concentração interna do metal, embora não significativa (máximo de $15 \%$ a mais para a dose de $100 \mu \mathrm{M}$ nas raízes), aos 33 dias de tratamento (Tabela 11). Esses dados indicam que provavelmente as plantas absorveram quase todo o Cd presente na solução já nos primeiros 11 dias de tratamento, e esse aumento foi mais rápido nas maiores doses. Como exemplo, podemos ver que na dose de $500 \mu \mathrm{M}$ haviam

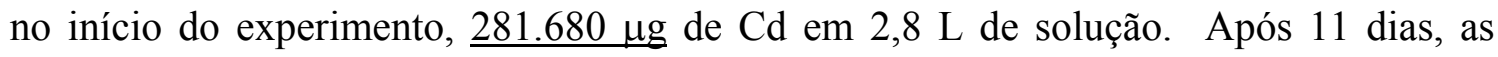
plantas absorveram em média $10.833 \mu \mathrm{g} \mathrm{g}^{-1}(\mathrm{ppm})$ de peso fresco (Tabela 11$)$, sendo que

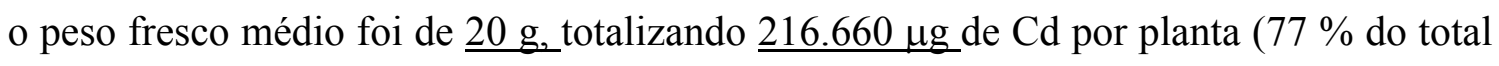
na solução). 


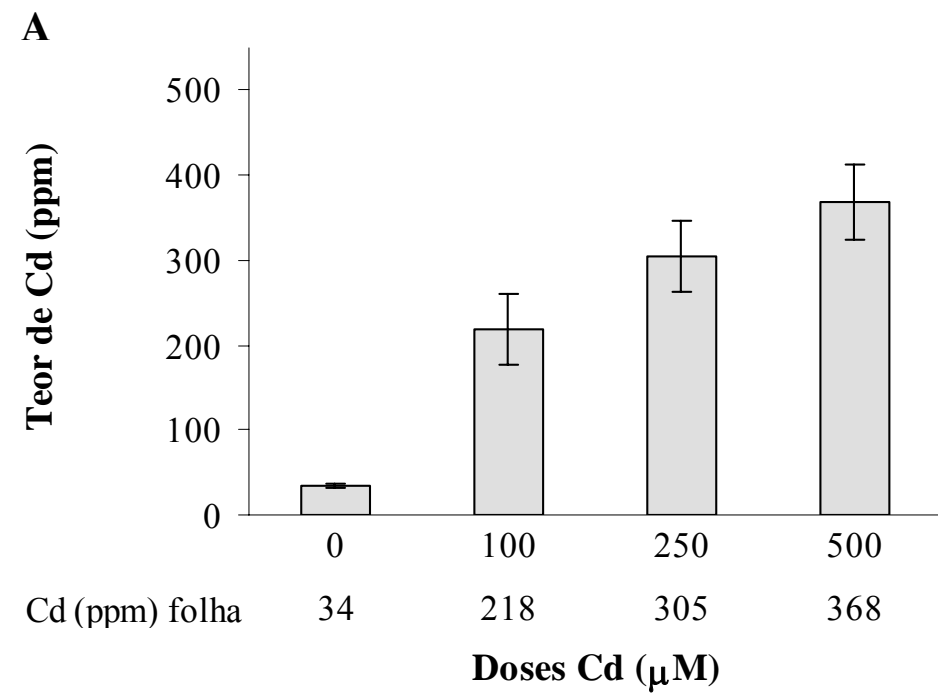

B

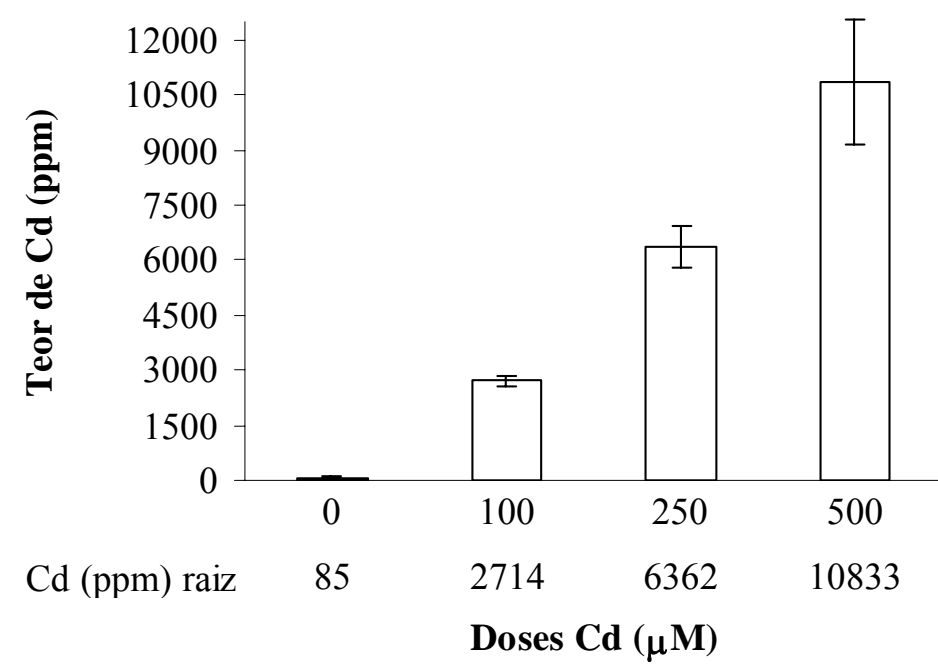

Figura 10 - Concentração média de cádmio (barra \pm desvio padrão) da parte aérea (A) e raízes (B) de plântulas de cana-de-açúcar após 11 dias de cultivo em solução nutritiva suplementada com concentrações crescentes de $\mathrm{Cd}(0 ; 100 ; 250$; e $500 \mu \mathrm{M}) \mathrm{n}=6(2$ plantas $\mathrm{x} 3$ vasos $)$. 


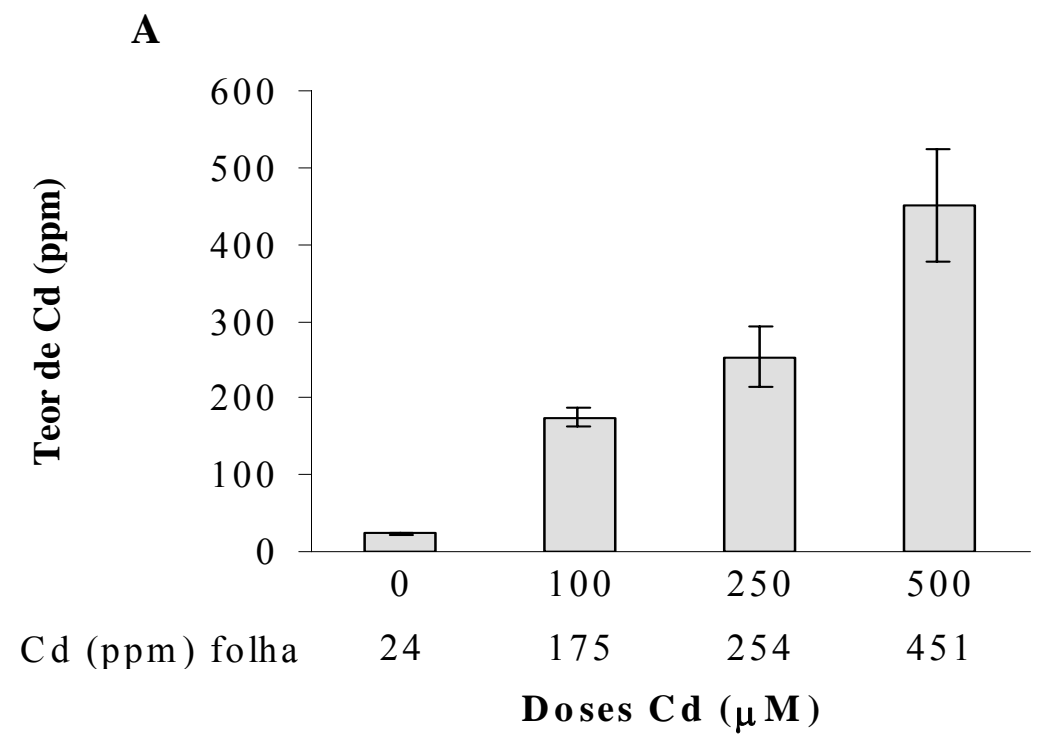

B

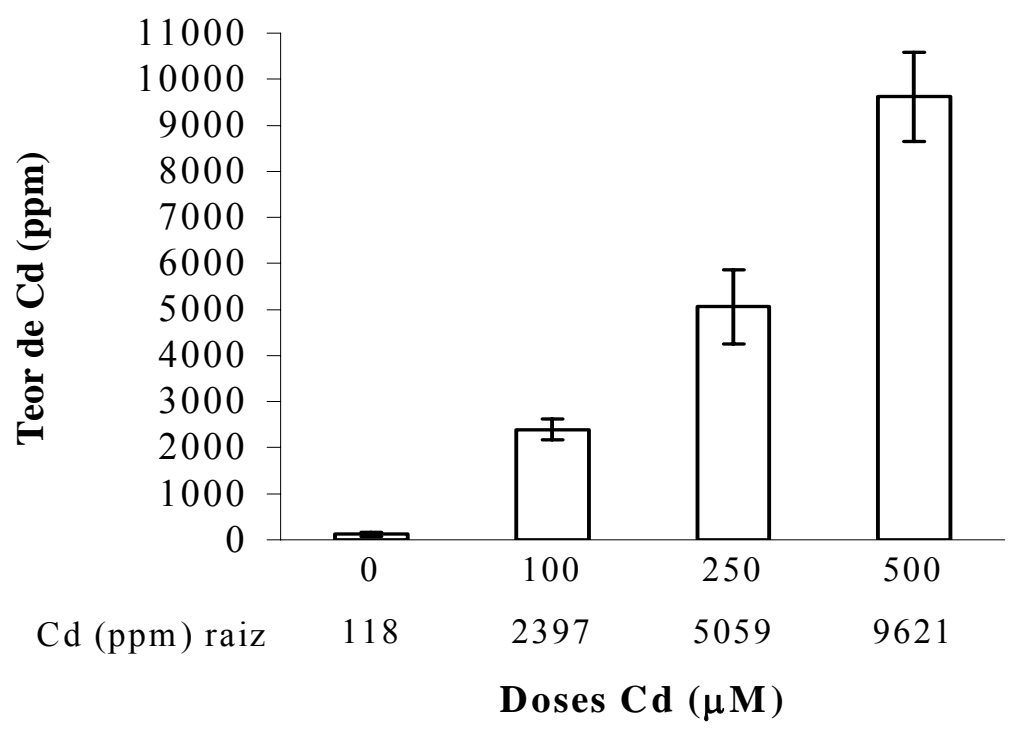

Figura 11 - Concentração média de cádmio (barra \pm desvio padrão) da parte aérea (A) e raízes (B) de plântulas de cana-de-açúcar após 33 dias de cultivo em solução nutritiva suplementada com concentrações crescentes de $\mathrm{Cd}(0$; $100 ; 250 ;$ e $500 \mu \mathrm{M}) . \mathrm{n}=6$ (2 plantas x 3 vasos $)$ 
Tabela 15. Análise de variância (The SAS System - The GLM Procedure) dos dados provenientes dos teores de cádmio na parte aérea de plântulas de cana-deaçúcar

\begin{tabular}{lcccc}
\hline FV & GL & $\mathbf{Q M}$ & $\mathbf{F}$ & Pr $>\mathbf{F}$ \\
\hline Repetição & 2 & 4372,0624 & 1,05 & Ns \\
Tratamento & 13 & 69338,8362 & 16,67 & $* *$ \\
$\quad$ Dose & 3 & 101616,1871 & 24,43 & $* *$ \\
$\quad$ Tempo & 2 & 209016,5393 & 50,24 & $* *$ \\
$\quad$ Dose * Tempo & 6 & 28296,5176 & 6,80 & $* *$ \\
Resíduo & 22 & 4160,0600 & & \\
Total & 35 & & & \\
\hline Ns= não significativo; *5\% significância***1\% significância; &
\end{tabular}

Ns = não significativo; $* 5 \%$ significância; $* * 1 \%$ significância; $\mathbf{C V}=42$

Tabela 16. Análise de variância (The SAS System - The GLM Procedure) dos dados provenientes dos teores de cádmio na parte aérea de plântulas de cana-deaçúcar com desdobramento do fator tempo

\begin{tabular}{lcccc}
\hline FV & GL & QM & F & Pr $>$ F \\
\hline 0 dias & 3 & $7,068194 \mathrm{E}-27$ & 0,0 & Ns \\
11 dias & 3 & 63238 & 15,20 & $* *$ \\
33 dias & 3 & 94971 & 22,83 & $* *$ \\
\hline
\end{tabular}

Tabela 17. Análise de variância (The SAS System - The GLM Procedure) dos dados provenientes dos teores de cádmio na parte aérea de plântulas de cana-deaçúcar com desdobramento do fatore tempo dose

\begin{tabular}{lcccc}
\hline $\mathrm{FV}$ & $\mathrm{GL}$ & $\mathrm{QM}$ & $\mathrm{F}$ & $\mathrm{Pr}>\mathrm{F}$ \\
\hline $0 \mu \mathrm{M}$ & 2 & 904,754011 & 0,22 & $\mathrm{Ns}$ \\
$100 \mu \mathrm{M}$ & 2 & 40049 & 9,63 & $* *$ \\
$250 \mu \mathrm{M}$ & 2 & 80083 & 19,25 & $* *$ \\
$500 \mu \mathrm{M}$ & 2 & 172870 & 41,55 & $* *$ \\
\hline
\end{tabular}


Tabela 18. Análise de variância (The SAS System - The GLM Procedure) dos dados provenientes dos teores de cádmio nas raízes de plântulas de cana-de-açúcar

\begin{tabular}{lcccc}
\hline FV & GL & QM & F & Pr $>\mathbf{F}$ \\
\hline Repetição & 2 & 1299252,9 & 0,78 & Ns \\
Tratamento & 13 & 40319506,6 & 24,16 & $* *$ \\
$\quad$ Dose & 3 & 76397550,4 & 45,77 & $* *$ \\
$\quad$ Tempo & 2 & 87899969,3 & 52,66 & $* *$ \\
$\quad$ Dose * Tempo & 6 & 19427081,7 & 11,64 & $* *$ \\
Resíduo & 22 & 1669100,8 & & \\
Total & 35 & & & \\
Ns = não significativo; *5\% significância; **1\% significância; $\mathbf{C V}=42$ &
\end{tabular}

Tabela 19. Análise de variância (The SAS System - The GLM Procedure) dos dados provenientes dos teores de cádmio nas raízes de plântulas de cana-de-açúcar com desdobramento do fator tempo

\begin{tabular}{lcccc}
\hline FV & GL & QM & F & Pr $>$ F \\
\hline 0 dias & 3 & $6,203855 \mathrm{E}-25$ & 0,0 & Ns \\
11 dias & 3 & 65258699 & 39,10 & $* *$ \\
33 dias & 3 & 49993015 & 29,95 & $* *$ \\
\hline
\end{tabular}

Tabela 20. Análise de variância (The SAS System - The GLM Procedure) dos dados provenientes dos teores de cádmio nas raízes de plântulas de cana-de-açúcar com desdobramento do fator dose

\begin{tabular}{lcccc}
\hline $\mathrm{FV}$ & GL & QM & $\mathrm{F}$ & $\mathrm{Pr}>\mathrm{F}$ \\
\hline $0 \mu \mathrm{M}$ & 2 & 11158 & 0,01 & $\mathrm{Ns}$ \\
$100 \mu \mathrm{M}$ & 2 & 6604670 & 3,96 & $*$ \\
$250 \mu \mathrm{M}$ & 2 & 33883169 & 20,30 & $* *$ \\
$500 \mu \mathrm{M}$ & 2 & 105682217 & 63,32 & $* *$ \\
\hline
\end{tabular}


O cádmio existe na crosta terrestre em baixas concentrações $(0,15-0,20$

$\mathrm{mg} \mathrm{kg}^{-1}$ ), geralmente associado ao zinco. Quantidades significativas e progressivas deste metal vêm sendo introduzidas no meio ambiente devido às atividades humanas (Ghoshroy et al, 1998). O Cd é um elemento altamente tóxico para os seres vivos. Os níveis críticos em soluções nutritivas, para os cultivos convencionais, foram relatados ser de $8 \mu \mathrm{M}$ para o trevo branco (Trifolium repens L.) e o milho (Zea maize); $14 \mu \mathrm{M}$ para o repolho (Brassica oleracea var. capitata) e $28 \mu \mathrm{M}$ para a gramínea Lolium perenne $\mathrm{L}$ (Yang et al., 1995). Destas espécies, a gramínea foi a mais tolerante ao metal, apresentando a menor redução do peso fresco, devido talvez, ao fato de possuir a menor taxa de translocação para a parte aérea (50 e 27 vezes menos que o repolho e o milho respectivamente) acumulando $\mathrm{Cd}$ principalmente nas raízes. O trevo mostrou ser o mais susceptível, mas com a maior taxa de absorção e translocação para parte aérea, acumulando o cádmio principalmente nesses tecidos (Yang et al., 1995). No outro extremo, plantas suculentas como Sedum alfredii, tiveram a capacidade excepcional de tolerar e hiperacumular grandes quantidades de Cd na parte aérea (Yang et al., 2004). As plantas de S. alfredii tiveram crescimento igual ao controle quando submetidas a dose de até $200 \mu \mathrm{M}$ de $\mathrm{Cd}$ e os teores de metal registrados para essa dosagem foram de 7.800 ppm e 2.300 ppm para folhas e raízes respectivamente. Os sintomas de intoxicação por metais apareceram a partir do tratamento com $400 \mu \mathrm{M}$ aumentando com o tempo de exposição. O acúmulo nos ramos e folhas aumento de forma diretamente proporcional a dose de Cd suplementada, sendo máxima para as folhas $(9.000$ ppm) na concentração de $400 \mu \mathrm{M}$, mas diminuindo drasticamente (4000 ppm) na dosagem máxima de $800 \mu \mathrm{M}$. O 
inverso foi observado nas raízes, onde o acúmulo foi muito inferior (⒋500 ppm) na dosagem de $400 \mu \mathrm{M}$ de $\mathrm{Cd}$, dobrando (até 9.000 ppm) na dosagem máxima de $800 \mu \mathrm{M}$ (Yang et al., 2004). Esses dados de absorção e acúmulo de Cd descritos para S. alfredii refletem o comportamento de uma planta hiperacumuladora de metais. Isto é, nas dosagens que a planta é capaz de crescer e se desenvolver bem, o acúmulo é principalmente na parte aérea, devido às elevadas taxas de translocação características. Para as dosagens que comprometem a viabilidade das plantas, o acúmulo é feito principalmente nas raízes envolvendo, provavelmente, mecanismos diferentes dos que atuam na parte aérea (Reeves et al., 1995).

Os resultados obtidos com cana neste trabalho confirmaram dados anteriores (Fornazier et al., 2002) sobre a capacidade de absorção e tolerância ao cádmio pela cana-de-açúcar, tolerando bem doses de $250 \mu \mathrm{M}$, com concentrações nas folhas e raízes de até 350 e 6.400 ppm respectivamente, mantendo seu crescimento (Tabela 11; Figura 10). Embora a cana-de-açúcar não seja uma hiperacumuladora de metais, apresenta grande tolerância ao Cd quando comparada com outras gramíneas (Yang et al., 1995) e a capacidade de acúmulo nas raízes foi muito elevada. É importante ressaltar que essa tolerância é demonstrada por plântulas de cana-de-açúcar, e como observado acima, plantas maduras toleram valores ainda maiores (Fornazier et al., 2002). 


\subsection{Purificação de clones EST para confecção de sondas}

A busca por metalotioninas (MTs) baseada na ferramenta keyword-search no banco de dados do SUCEST da UNICAMP (http://sucest.lad.dcc.unicamp.br/en/), permitiu a identificação de 84 clusters com valor $E<10^{-5}$ mas, somente os clusters com valor $E<10^{-7}$ foram analisados, num total de 54 (Figueira et al., 2001). As MTs foram classificadas de acordo com a distribuição dos dois domínios ricos em cisteína em MT tipo I, MT II, MT III e MT IV de acordo com Rauser (1999). Baseado em Figueira et al. (2001) foi escolhido um total de 34 reads mais representativos de cada tipo de metalotioneína, agrupados em 16 clusters para serem re-seqüenciados.

O re-seqüenciamento indicou que os reads SCSFSD2064C07.g, SCRUFL3063A10.g, SCSGHR1071G06.g e SCSFSD1066A01.g possuíam as seqüências mais próximas da região 5' dos genes que codificam os peptídeo MT I, MT II, MT III e MT IV respectivamente, apresentando alta similaridade com os demais reads componentes de cada cluster (Bastos A.E.R., dados não publicados). Esses quatro clones (reads) foram escolhidos para serem utilizados como sondas (cDNA) nas análises por Southern blot e northern blot.

Os insertos (reads) contidos no vetor pSPORT 1 foram amplificados usando os primers T7/SP6. Os produtos de PCR foram digeridos com as enzimas (EcoRI-HindIII) e os fragmentos separados em gel de 1\% agarose. O tamanho (pb) dos fragmentos foi confirmado por comparação com o tamanho das mesmas seqüências depositadas no banco de dados do SUCEST, e purificados do gel. 


\subsection{Análise por Southern blot}

O DNA total da parte aérea de plantas de cana de açúcar foi digerido empregando um total de 6 enzimas de restrição distintas, transferido para membranas de nylon, e sondado com cada um dos cDNAs correspondentes aos três tipos de metalotioneína (MT) I, MT II e MT III, mediante a técnica de Southern blot. Estas hibridizações foram feitas para estimar o número de cópias de cada gene. Foram realizados mais de um ensaio de hibridização para cada sonda. Inicialmente, testou-se o uso de enzimas de corte freqüente para digestão, mas a resolução obtida foi baixa, e optou-se por empregar apenas enzimas de corte raro.

Os genes dos três tipos de metalotioneínas estão presentes em pequeno número no genoma da cana-de-açúcar. Tipicamente, todas as sondas geraram, com as digestões obtidas com enzimas de corte raro, cerca de 6 a 10 fragmentos (Figura 12, 13 e 14). Para a sonda de MT I, a melhor resolução foi obtida com a enzima DraI, quando foi possível detectar 8 bandas nítidas (Figura 12B; linha 4). Esse padrão de bandas foi observado em réplicas independentes. A digestão com as enzimas MboI e HaeIII não produziram hibridização com nitidez das bandas, mas confirmam o pequeno número de cópias desse gene. Resultados similares em termos de número de fragmentos foram obtidos empregando a enzima EcoRV (Figura 12A) para digestão.

Os ensaios empregando a sonda específica para MT II (Figura 13) tiveram resultados similares com cerca de 10 fragmentos para as enzimas de corte raro testadas (EcoRI; EcoRV; DraI; e HindIII). O padrão de digestão obtido com as enzimas EcoRI e DraI foi consistente entre as réplicas independentes (Figura 13 A e B). Já as 
hibridizações com a sonda específica para o gene MT III foram menos nítidas, mas os resultados indicam um número de cópias similar aos dois anteriores (cerca de 8), revelado apenas pelas enzimas HindIII e DraI (Figura 14).

Os resultados obtidos utilizando a sonda para MT IV apresentaram o mesmo padrão de restrição que MT III com todas as enzimas e para todas as repetições. Ante esses resultados não esperados e para descartar qualquer possibilidade de interpretação errônea, os clones EST correspondentes a MT III e MT IV foram re seqüenciados nos sentidos 5'e 3'. O clone MT III teve a seqüência de nucleotídeos confirmada com os bancos de dados do SUCEST e NCBI, assim como a seqüência conceitualmente traduzida a proteína. O re-seqüênciamento do clone para MT IV não ficou de boa qualidade impossibilitando a identificação da seqüência. As dificuldades práticas em se realizar novas reações de seqüênciamento fizeram com que este último seja descartado da análise e interpretação de dados. 
A

$\lambda$ HindIII MTI EcoRI EcoRV DraI HindIII

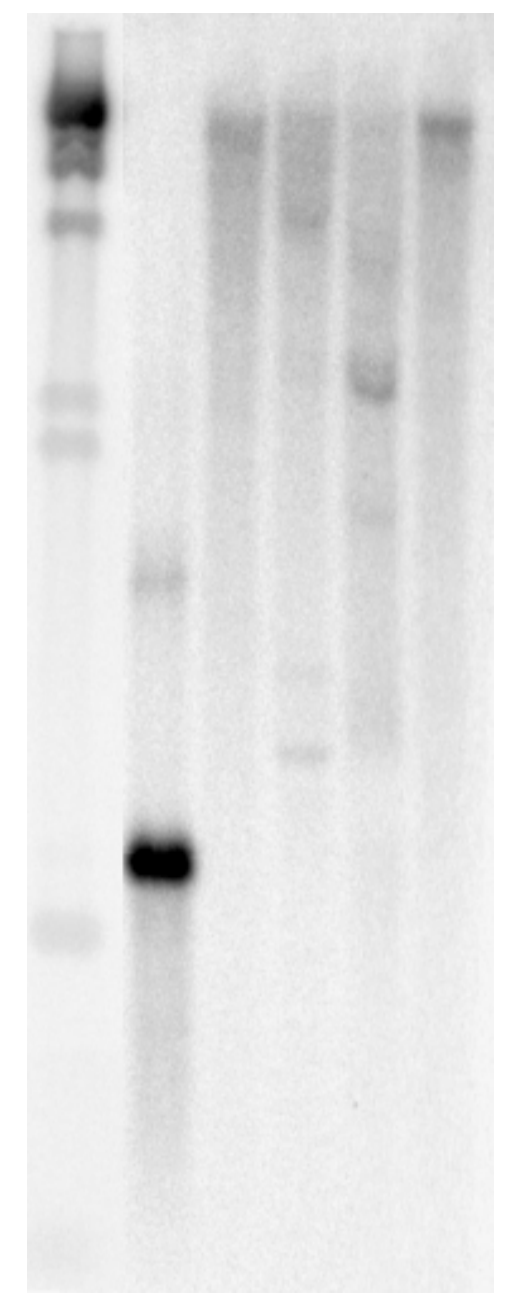

B

$\lambda$ HindIII MT1 EcoRI DraI MboI HaeIII

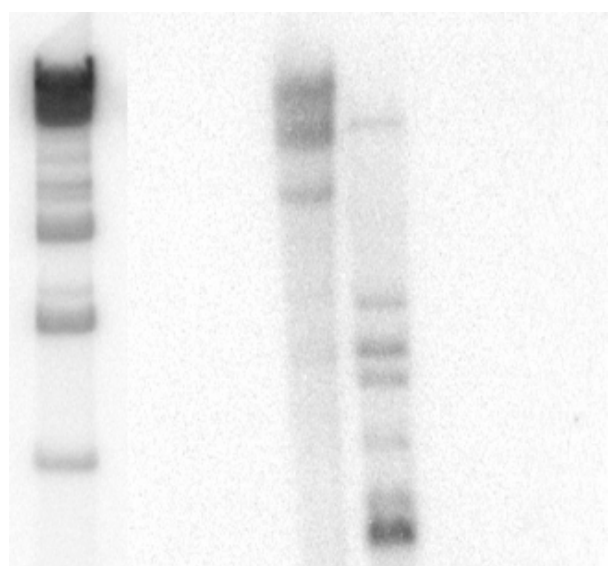

Figura 12 - Southern blot para determinação do número de cópias dos genes de Metalotioneína I no genoma da cana-de-açúcar. (A): Linha 1= marcador de peso molecular $\lambda$ digerido com HindIII; 2: controle positivo (sonda MT I); 3: DNA digerido com EcoRI; 4: EcoRV; 5: DraI; 6: HindIII. (B) Linha $1=$ marcador de peso molecular $\lambda$ digerido com HindIII; 2: controle positivo (sonda MT I); 3: DNA digerido com EcoRI; 4: DraI; 5: MboI; 6: HaeIII 
A

ג. HindIII MT I FcoRI EcoRV DraI HindIII

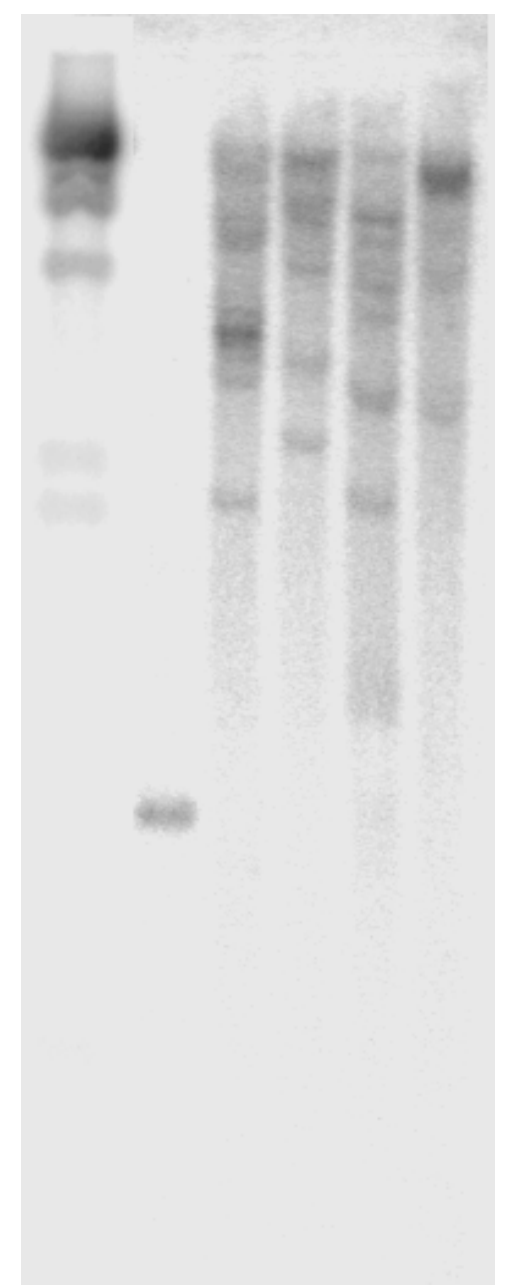

B

EcoRI DraI MboI HaeIII $\lambda$ HindIII

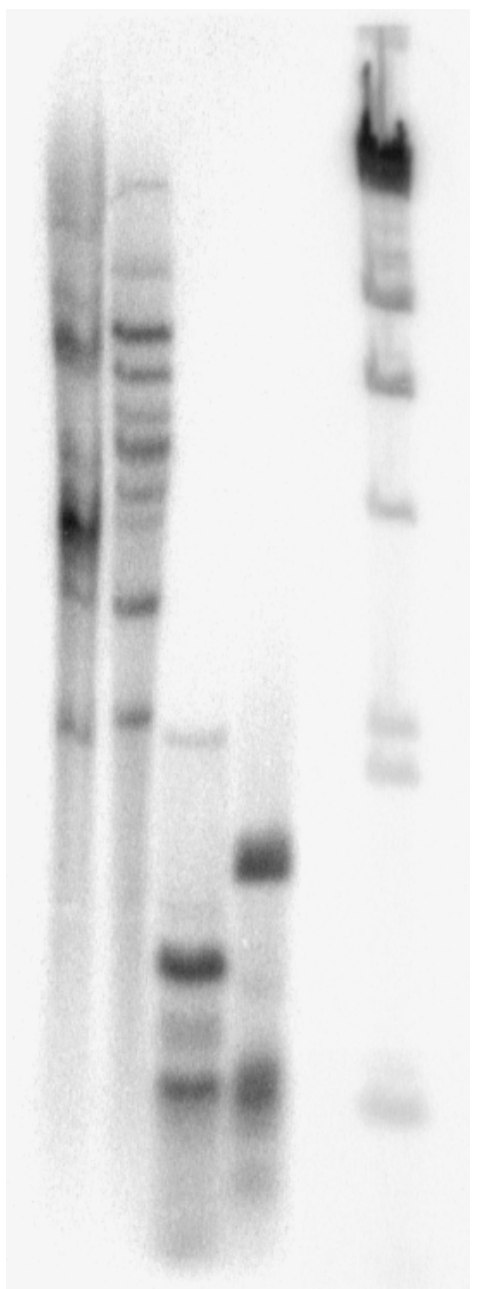

Figura 13 - Southern blot para determinação do número de cópias dos genes de Metalotioenína II no genoma da cana-de-açúcar. (A): Linha 1= marcador de peso molecular $\lambda$ digerido com HindIII; 2: controle positivo (sonda MT I); 3: DNA digerido com EcoRI; 4: EcoRV; 5: DraI; 6: HindIII. (B) Linha 1 = DNA digerido com EcoRI; 2: DraI; 3: MboI; 4: HaeIII; 5: marcador de peso molecular $\lambda$ digerido com HindIII 
A

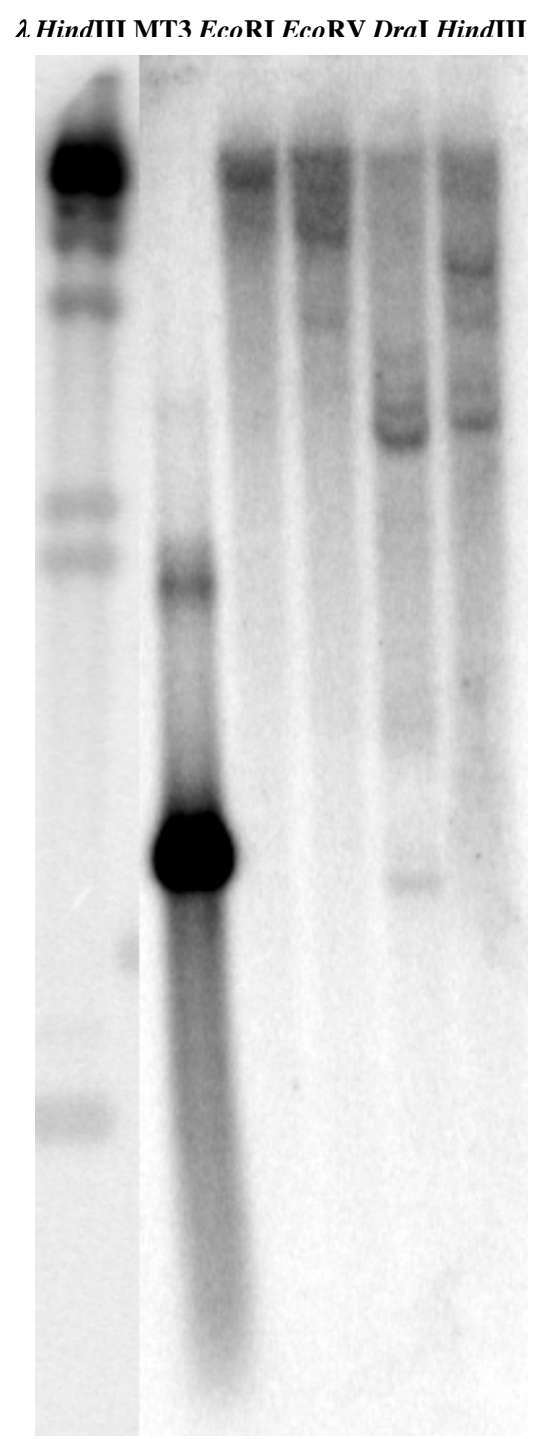

B

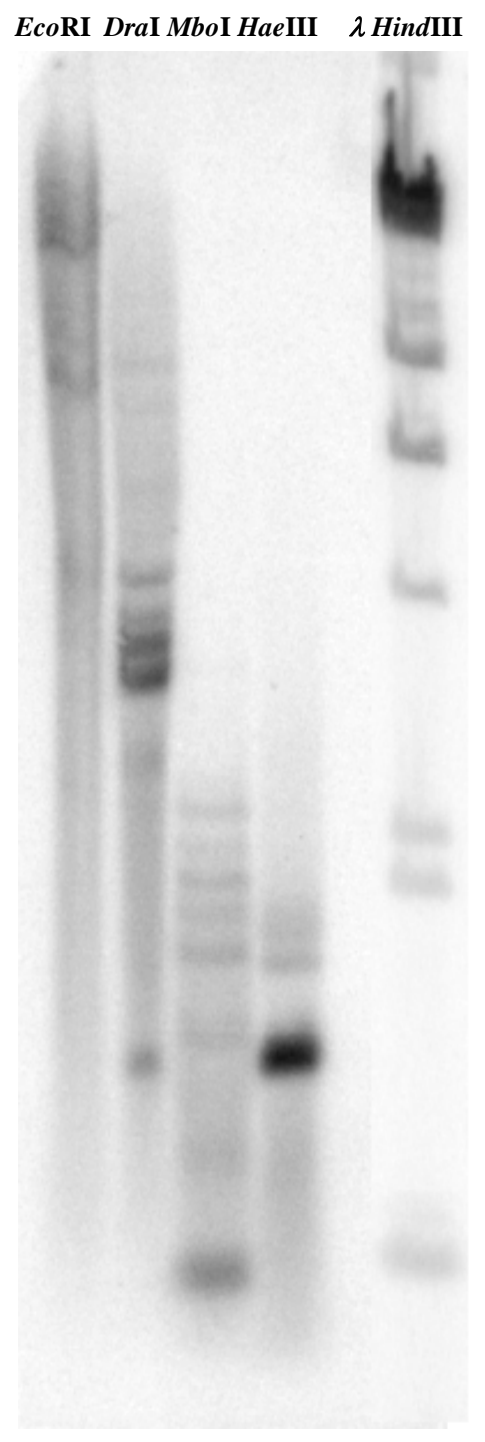

Figura 14 - Southern blot para determinação do número de cópias dos genes de Metalotioenína III no genoma da cana-de-açúcar. (A): Linha 1= marcador de peso molecular $\lambda$ digerido com HindIII; 2: controle positivo (sonda MT III); 3: DNA digerido com EcoRI; 4: EcoRV; 5: DraI; 6: HindIII. (B) Linha 1 = DNA digerido com EcoRI; 2: DraI; 3: MboI; 4: HaeIII; 5: marcador de peso molecular $\lambda$ digerido com HindIII 
O genoma de Arabidopsis contém uma família gênica com apenas 7 membros dos 4 tipos de metalotioneínas (Cobbett e Goldsbrough, 2002). Os genes MT1a e MT1c estão localizados próximos, numa região repetida invertida do cromossomo 1; os genes MT2a e MT3 em locos distintos no cromossomo 3; os genes MT4a e MT4b no cromossomo 2 mas não ligados fisicamente; e o gene $M T 2 b$ no cromossomo 5 , que também contém um pseudo-gene $M T 1 b$. De forma similar, as metalotioneínas têm sido relatadas como integrantes de pequenas famílias multigênica para os genomas de ervilha, algodão, grão-de-bico, tomate, batata doce, alcachofra de Jerusalém, e arroz (Foley \& Singh, 1994; Hudspeth, et al., 1996; Muñoz et al, 1998 Giritch et al., 1998; Chen et al 2003; Chang et al., 2004; Hsieh, et al, 1995). Além de Arabidopsis, genes dos quatro tipos de metalotioneína só foram encontrados em arroz e cana-de-açúcar (Cobbett \& Goldsbrough, 2002). Análises dos bancos de dados de seqüências de arroz (www.tigr.org; www.gramene.org) indicaram a presença de 9 cópias de genes MTs distribuídos em vários cromossomos, sendo cinco do tipo I, localizados, dois de cada nos cromossomos 11 e 12 e um no cromossomo 3; dois do tipo MT II nos cromossomos 1 e 5, e um de cada dos tipos MT III e MT IV localizados nos cromossomos 1 e 10 respectivamente. Em algodão foram identificados 3 genes tipos MT I agrupados em linha no mesmo cromossomo (Hudspeth et al., 1996). Em Cicer arietinum (grão-de-bico), foram identificados dois genes, CanMT-1 e CanMT-2, correspondentes aos tipos I e II. O Southern blot revelou a presença de uma a três cópias de CanMT-1 e só uma de CanMT-2 (Muñoz et al., 1998). Em tomate, observou-se algo similar, mas para MT II sendo encontradas três cópias diferentes deste tipo, chamadas LEMT-1; LEMT-3 e LEMT-4. Um segundo gene chamado LEMT-2 foi investigado não apresentando homologia de 
seqüência com nenhum dos gene MTs conhecidos até agora. LEMT-1 e LEMT-3 estão localizados nos cromossomos 9 e 4 respectivamente, sendo que LEMT-3 poderia estar em duas cópias no mesmo loco. LEMT-4 e LEMT-2 se encontram em cópias simples em diferentes locos no cromossomo 6 (Girith et al., 1998). MTs do tipo II foram também encontradas em Vicia faba, Heliantus tuberosus e Ipomea batatas. Na ervilha foi encontrada uma única cópia do gene MT tipo II (Foley \& Singh, 1994). Por outro lado, a análise de Southern blot do genoma da alcachofra de Jerusalém (Heliantus tuberosus) evidenciou de 2 a 7 fragmentos de restrição para as diferentes enzimas utilizadas (Chang et al, 2004), indicando que htMT2 é codificado por uma família multigênica. A situação intermediária ocorre em Ipomea batatas (batata doce) onde 2 a 4 cópias de um gene tipo MT II (Y459) foram identificadas. Um segundo gene chamado G14 foi também encontrado em batata doce. Este está presente com 2 cópias distintas com alta similaridade com o gene que codifica para MT III (Chen, et al., 2003). Em outro trabalho com batata doce foi identificado um único gene tipo MT I (Huang et al, 2001). Como em Arabidopsis e arroz, o genoma de Ipomea batatas poderia ser portador de uma ou mais cópias dos diversos tipos de genes MTs. Os genes do tipo MT III foram identificados principalmente em frutos e folhas de plantas sem frutos. Há conhecimento da existência de genes deste tipo no kiwi (Ledger \& Gardner, 1994), banana (Clendennen \& May, 1997), maçã (Reid \& Ross, 1997), uva (Davies \& Robinson, 2000) e dendê (Abdullah, et al., 2002), assim como também em Arabidopsis, arroz e cana de açúcar. Em Elaeis guineensis (dendê) foram isoladas e caracterizadas duas cópias do gene MT III chamadas de MT3-A e MT3-B, ambos em cópia única. Nas frutas, estudou-se a expressão deste gene, mas não há relatos com relação ao número de cópias. 
Em cana-de-açúcar, a poliploidia dificulta a interpretação dos dados para o estabelecimento do número de cópias de genes. É reconhecido que um gene num único loco no genoma estaria presente com aproximadamente 10 alelos em cana-de-açúcar, cada uma representando potencialmente um haplótipo, sendo 8 ou 9 correpondente a $S$. officinarum e 1 ou 2 a S. spontaneum (Grivet et al., 2003). Esse número de cópias esperado por genoma (cerca de 10) é consistente com os números de fragmentos estimados nas análises de Southern aqui apresentadas (média de fragmentos próximo a 10). Portanto, esses genes são codificados por pequenas famílias gênicas, sendo cada tipo de metalotioneína representada por um ou poucos membros no genoma haplóide, mas com diversas cópias no genoma poliplóide. No genoma do diplóide Nicotiana glutinosa L um gene tipo MT II aparece como cópia única (Choi et al, 1996). No entanto, quando o genoma do anfidiplóide $N$. tabacum cv Xanthi é sondado com o mesmo gene, o Southern blot revela duas bandas para cada enzima utilizada (Choi et al, 1996). Alternativamente, como observado para Arabidopsis, poderiam existir várias cópias ou membros do mesmo tipo de gene (MTIa, MTIb, etc.) no genoma haplóide de cana-deaçúcar, que gerariam um padrão de bandas específico para cada cópia. Cada banda detectada no Southern representaria uma dessas cópias ou membros. As cópias oriundas dos diversos cromossomos homólogos poderiam ser similares, e estariam representadas por fragmentos do mesmo tamanho, assumindo que os cromossomos homólogos não fossem muitos distintos em termos de polimorfismo de restrição. Os cromossomos homeólogos certamente gerariam bandas distintas. Nesse caso, o número de genes de cada tipo de metalotioneínas poderia ser similar ao encontrado para arroz (de 1 a 5 cópias dos diferentes genes), com alguns fragmentos extras devido ao polimorfismo entre 
cromossomos homólogos e/ou homeólogos. Em Festuca rubra cv Merlin, o gene mcMT1, foi investigado para número de cópias. Duas bandas distintas foram detectadas sugerindo a existência de pelo menos dois locos para esse gene. Além disso, baseados na intensidade das bandas (uma é o dobro de tamanho e intensidade da outra) e sabendo que a sonda em questão não é clivada pela enzima utilizada, os autores sugerem que pelo menos duas cópias de um dos genes existisse no genoma dessa gramínea (Ma et al., 2003). Portanto, a família de genes de metalotioneínas parece ser composta por um número limitado de cópias de cada membro.

\subsection{Análise de expressão por northern blot}

Neste trabalho investigou-se a expressão espacial e temporal dos genes de metalotioneína (MT) dos tipos I, MT II e MT III, mediante northern blots. Foi analisada a expressão de metalotioneínas em relação a exposição de plântulas de cana-de-açúcar a doses crescentes de $\mathrm{Cu}(0 ; 50 ; 100 ; 250$ e $500 \mu \mathrm{M})$ e $\mathrm{Cd}(0 ; 100 ; 250$; e $500 \mu \mathrm{M})$. RNA total foi extraído de amostras de tecidos de parte aérea e raízes de plântulas dos diversos tratamentos, separado em gel por eletroforese, transferido para membrana de nylon, e hibridizado com sondas dos genes (cDNA) para metalotioneínas dos Tipos I; II e III (Figura 15A a 20A). Cada membrana também foi sondada com fragmento do gene ribossomal, que inclui partes de $18 \mathrm{~S}$ e $28 \mathrm{~S}$, e o $5,8 \mathrm{~S}$ completo (Figura 15B a 20B), para padronizar as quantidades de RNA total carregadas no gel, e permitir a análise quantitativa comparativa entre tratamentos, de forma a detectar indução/repressão de 
transcritos. A normalização da concentração de RNA estimada por espectrofotometria não apresenta acurácia. Também, buscou-se incluir repetições das membranas e hibridizações, mas não foi possível preparar replicações para RNA de raízes de plântulas crescidas em $\mathrm{Cu}$ aos 33 dias.

De forma geral, o padrão de expressão dos genes dos três tipos de metalotioneínas seguiram os resultados descritos a partir dos dados de seqüenciamento de EST do projeto SUCEST e suas respectivas freqüência de ocorrência nos diversos tecidos empregados na produção das bibliotecas de cDNA (Figueira et al., 2001). Houve um maior nível de expressão constitutiva para a MT I (Figura 15 e 18), seguido de MT II (Figura 16 e 19) e por último de MT III (Figura 17 e 20). Em termos de especificidade, a MT I demonstrou maior expressão em raízes do que as metalotioneínas II e III. Porém, MT I também apresentou alta expressão em tecido aéreo (Figura 15 e 18), assim como a MT II (Figura 16 e 19). Ocorreu alguma expressão de MT II em raízes, enquanto que MT III apresentou quase exclusivamente expressão em tecidos aéreos, principalmente aos 33 dias (linhas do controle; Figura 17 e 20). A expressão diferencial de genes MTs têm sido observada em tomate, Arabidopsis, arroz, V. faba e batata doce. (Giritch et al., 1998; Guo et al., 2003; Hsieh et al., 1995; Foley \& Singh, 1994; Huang et al, 2001; Chen et al., 2003). De modo geral, tem sido descrito que a expressão de MT I tende a ser maior em raízes do que em parte aérea, enquanto que o oposto ocorre com MT II conforme foi observado para a cana-de-açúcar. Já MT III tem sido principalmente descrita com maior expressão em frutos na maturação, mas também em altos níveis em folhas (Cobbett e Goldsbrough, 2002). 
Em Arabidopsis, o gene MT1a se expressa exclusivamente nas raízes de plantas sem nenhum tratamento, e o mesmo acontece para os genes MT2a e MT3 nas folhas. Já o gene $M T 2 b$, embora que preferencialmente em folhas, se expressa também em raízes (Guo et al., 2003). Em tomate, os genes tipo MT II, LEMT-1 e LEMT-4 confirmaram essa regra sendo preferencialmente expressos em órgãos da parte aérea (flores e folhas). No entanto LEMT-3 (um terceiro gene tipo MT II) contradiz essa sugestão sendo expresso, quase que exclusivamente, em raízes (Giritich et al., 1998). A maior expressão em raízes em relação às folhas para o gene MT I foi relatada para plantas de Pea sativum L., milho, trigo, Casuarina glauca e festuca (Evans et al., 1990; de Framond, 1991; Snowden \& Gardner, 1993; Laplaze et al, 2002; Ma et al., 2003;). Entretanto, o gene wali-1 de trigo, apesar de ser altamente expresso em raízes, quando investigado em folhas sem nenhum tratamento, apresentou níveis maiores de expressão, constituindo-se em mais um exemplo de que os diversos genes MTs são preferencialmente expressos nos diversos tecido.

Portanto, pode se concluir que o nível elevado de expressão constitutiva de MT I, seguido de MT II, assim como o perfil espacial de expressão dos genes de MT I, II e III em cana-de-açúcar seguiram o padrão geral observado em outros sistemas vegetais.

Os géis apresentaram, aproximadamente, concentrações similares de RNA total, estimadas por espectrofotometria e ajustados visualmente por intensidade no gel. Para a interpretação rigorosa dos resultados do controle da expressão gênica, por tratamentos com metais, os dados de intensidade das bandas geradas pela hibridização com as sondas de metalotioneínas foram normalizados pela estimativa densitométrica das bandas dos RNAs ribossômicos usando o programa ImageQuant. Os valores estimados 
de intensidade das bandas das metalotioneínas foram dividos pelos valores de intensidade dos fragmentos de RNA ribossômico resultante da hibridização com sonda específica para cada amostra. Esse índice obtido para cada tratamento de cada replicação, foi comparado ao valor do controle (ausência de metais) de forma a padronizar e estimar o aumento ou diminuição relativa da intensidade das bandas de metalotioneínas causadas pelos metais.

Os dados relativos às intensidade de bandas (dados não mostrados) indicaram que não houve indução ou repressão importante na expressão dos genes de metalotioneína I, MT II ou MT III nas condições e concentrações empregadas de cobre.

A expressão de MT I não parece ser afetada pelo cobre, mesmo nas maiores dosagens, apenas uma discreta redução dos transcritos para a dose de $50 \mu \mathrm{M}$ na parte aérea e raízes aos 11 dias seguida de um aumento para a mesma dose aos 33 dias. Houve, com o aumento na concentração de $\mathrm{Cu}$, uma pequena tendência de redução na expressão média de MT II em folhas, mais aos 11 dias do que aos 33 dias, acompanhada de uma tendência de aumento de expressão média nas raízes aos 11 dias (Figura 16). Houve também uma tendência de maior expressão de MT III em folhas aos 33 dias com o aumento na concentração de $\mathrm{Cu}$ (Figura 17).

Apesar de existir diversos relatos sobre a indução na expressão de metalotioneínas (principalmente MT I) por tratamento com cobre para diversos sistemas, não existe uma tendência pré-definida sobre o efeito desse metal na modulação da expressão desses genes, uma vez que também foi observada repressão por cobre ou mesmo ausência de efeito. Os genes MT1a, MT2a, MT2b e MT3 de Arabidopsis, e MT1 
de trigo foram induzidos por cobre (Snowden et al., 1995; Garcia-Hernandez, et al., 1998; Guo et al., 2003). Em Heliantus tuberosus, a expressão do gene htMT2 foi reduzida de forma inversamente proporcional á concentração de cobre (Chang, et al., 2004). Em tabaco, baixas concentrações de $\mathrm{Cu}$ aumentaram a expressão de um gene do tipo MT 2 enquanto que altas doses a inibiram (Choi et al., 1996). Em tomate, o cobre provocou respostas contrastantes entre três genes tipo MT II, sendo que, houve um pequeno aumento na expressão de $L E M T 1$, repressão na expressão de $L E M T 3$, e não houve mudanças na expressão de LEMT4 (Giritich et al., 1998). O nível de transcrito de MTs investigados em Vicia faba, também não evidenciaram mudanças na expressão após tratamento com cobre (Foley \& Singh, 1994).

No presente trabalho, os dados sugerem que os genes de metalotioneínas de cana-de-açúcar são pouco afetados ou não são modulados por Cobre. 
PARTE AÉREA

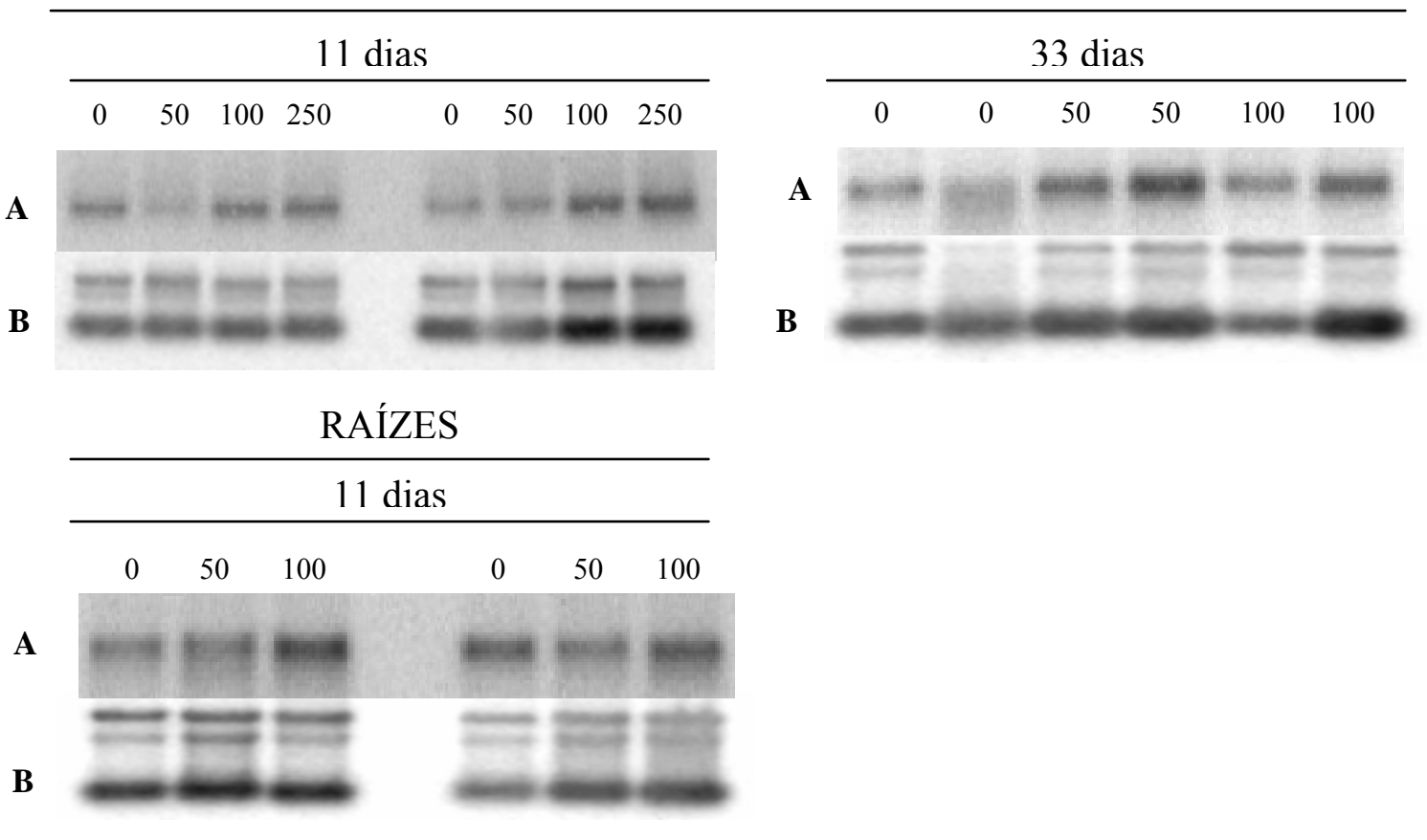

Figura 15 - Northern blot de membranas contendo RNA total extraído de plantas de cana de açúcar após tratamento com doses crescentes de cobre, hibridizadas com sonda de Metalotioneína I (A) ou gene ribossomal (B). Tratamentos com $0 \mu \mathrm{M}$ (controle sem cobre); $50 \mu \mathrm{M} ; 100 \mu \mathrm{M}$; e $250 \mu \mathrm{M}$ de cobre 
PARTE AÉREA

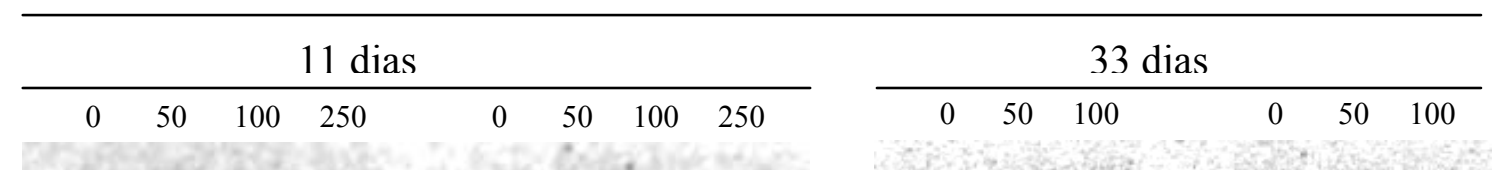

A

A

B

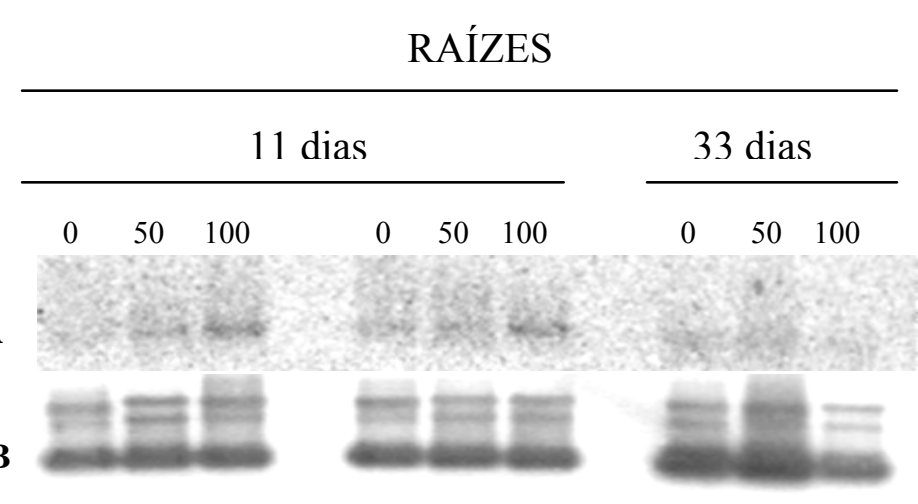

A

B

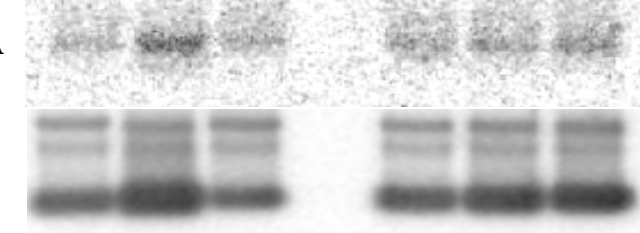

Figura 16 - Northern blot de membranas contendo RNA total extraído de plantas de cana de açúcar após tratamento com doses crescentes de cobre, hibridizadas com sonda de Metalotioneína II (A) ou gene ribossomal (B). Tratamentos com $0 \mu \mathrm{M}$ (controle sem cobre); $50 \mu \mathrm{M} ; 100 \mu \mathrm{M}$ e $250 \mu \mathrm{M}$ 
PARTE AÉREA

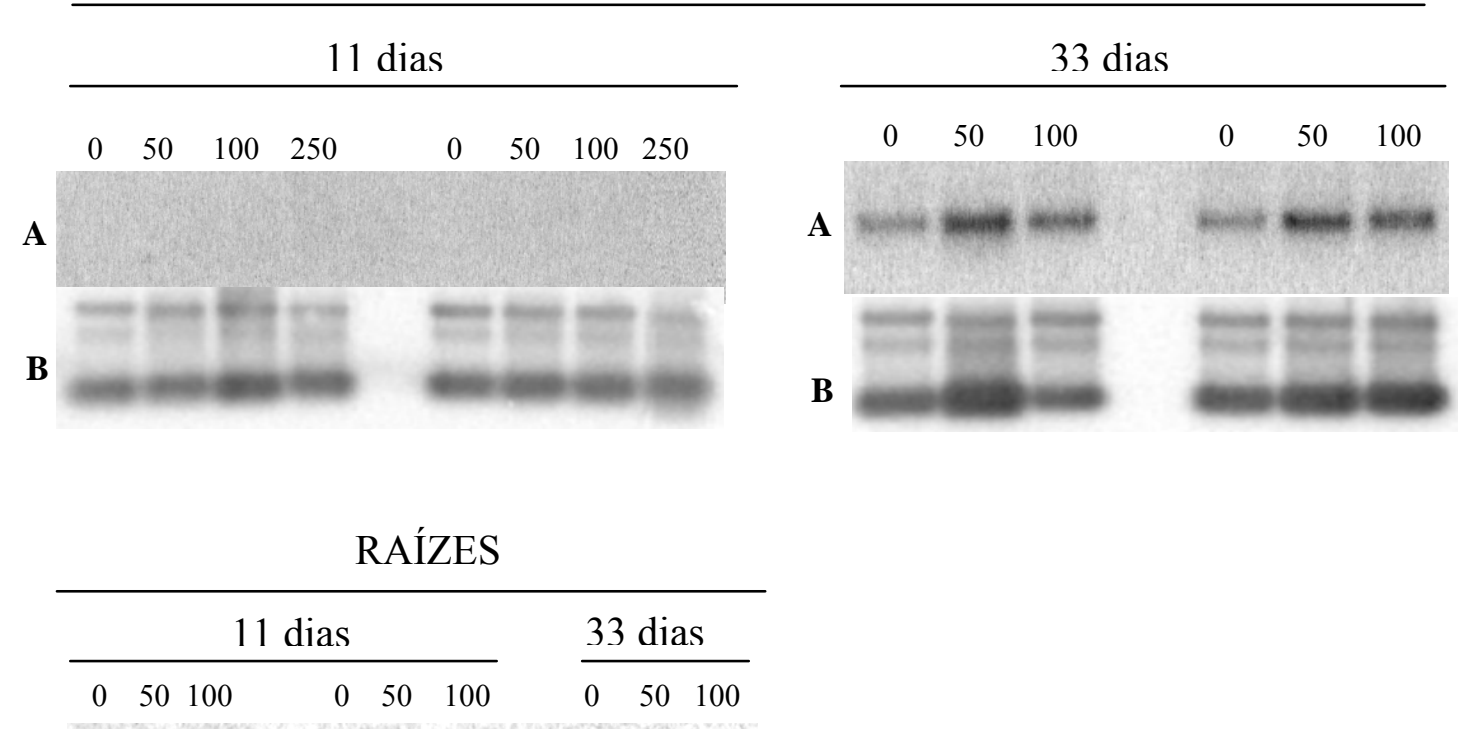

A

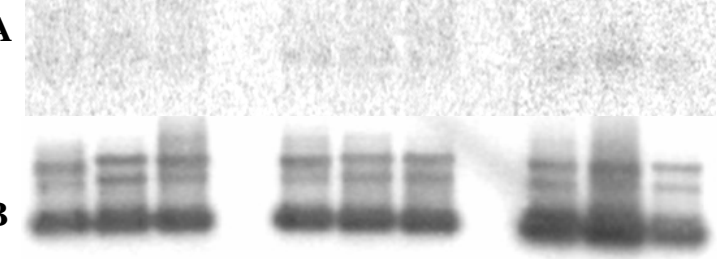

Figura 17 - Northern blot de membranas contendo RNA total extraído de plantas de cana de açúcar após tratamento com doses crescentes de cobre hibridizadas com sonda de Metalotioneína III (A) ou gene ribossomal (B). Tratamentos com $0 \mu \mathrm{M}$ (controle sem cobre); $50 \mu \mathrm{M} ; 100 \mu \mathrm{M}$ e $250 \mu \mathrm{M}$ 
Em relação ao tratamento com doses crescentes de cádmio, parece haver uma indução na expressão de MT I na parte aérea aos 11 e 33 dias, e em raízes aos 11 dias, enquanto ocorre um decréscimo destes transcritos em raízes aos 33 dias nas mesmas condições (Figura 18). Já os transcritos de MT II parecem ser induzidos apenas em raízes aos 11 dias, mas foram reprimidos aos 33 dias em raízes e parte aérea (Figura 19). O aumento na concentração de $\mathrm{Cd}$ no meio parece induzir um acúmulo de transcritos de MT III na parte aérea e raízes, principalmente aos 11 dias, enquanto que aos 33 dias ocorre um decréscimo desse mRNA nas raízes. De modo geral, pode-se concluir que ocorre um acúmulo de transcritos de MT nas raízes aos 11 dias levemente proporcional (exceto para MT III) à concentração de $\mathrm{Cd}$, que é seguido de um decréscimo de transcritos, também paralelo aos teores de Cd na solução, aos 33 dias. Da mesma forma, existe uma indução de MT I e principalmente MT III na parte aérea, com o aumento da concentração de cádmio na solução, mais acentuada aos 11 dias (Figuras 18 e 20). 
PARTE AÉREA

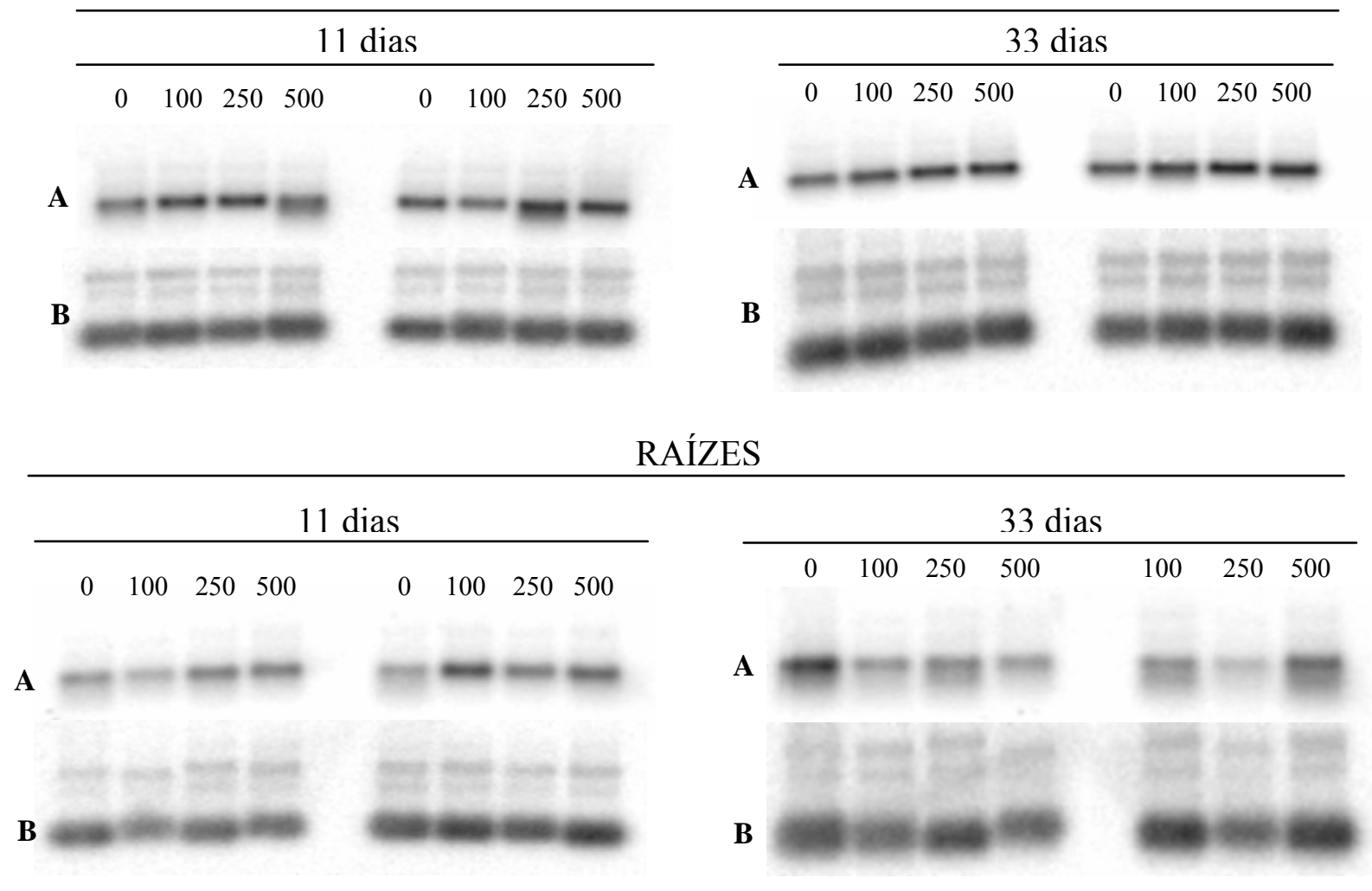

Figura 18 - Northern blot de membranas contendo RNA total extraído de plantas de cana de açúcar após tratamento com doses crescentes de cádmio hibridizadas com sonda de Metalotioneína I (A) ou gene ribossomal (B). Tratamentos com $0 \mu \mathrm{M}$ (controle sem cádmio); $100 \mu \mathrm{M} ; 250 \mu \mathrm{M}$; e 500 $\mu \mathrm{M}$ 
PARTE AÉREA

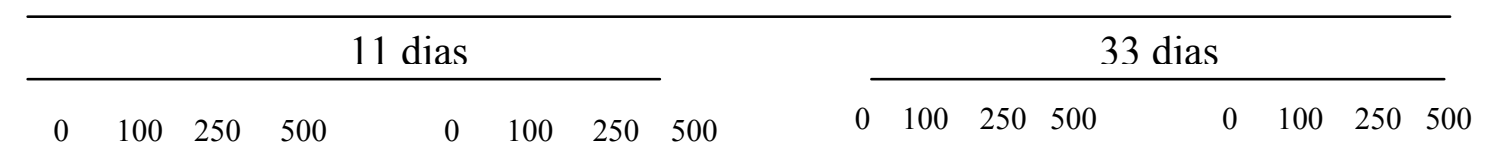

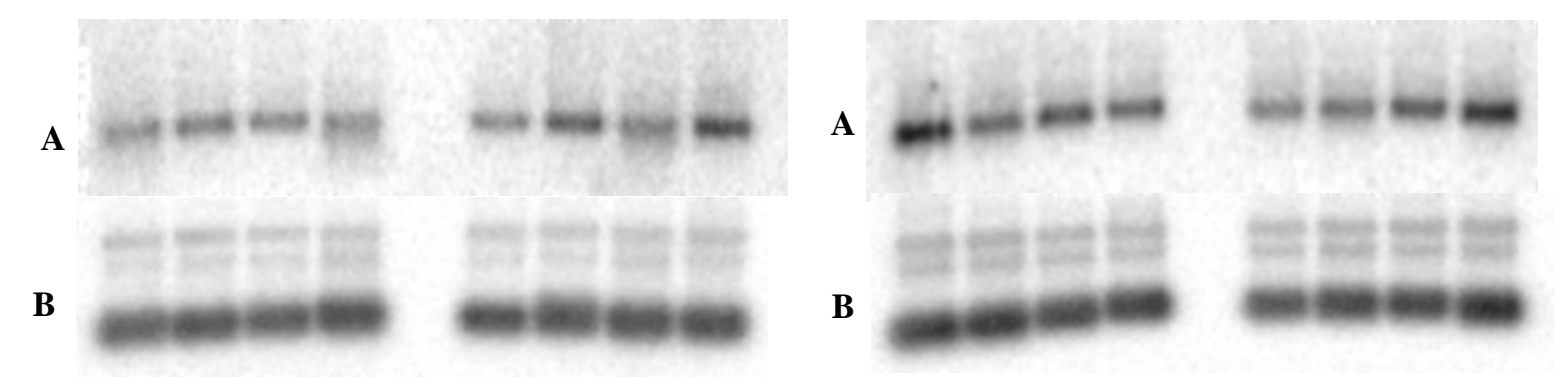

\section{RAÍZES}

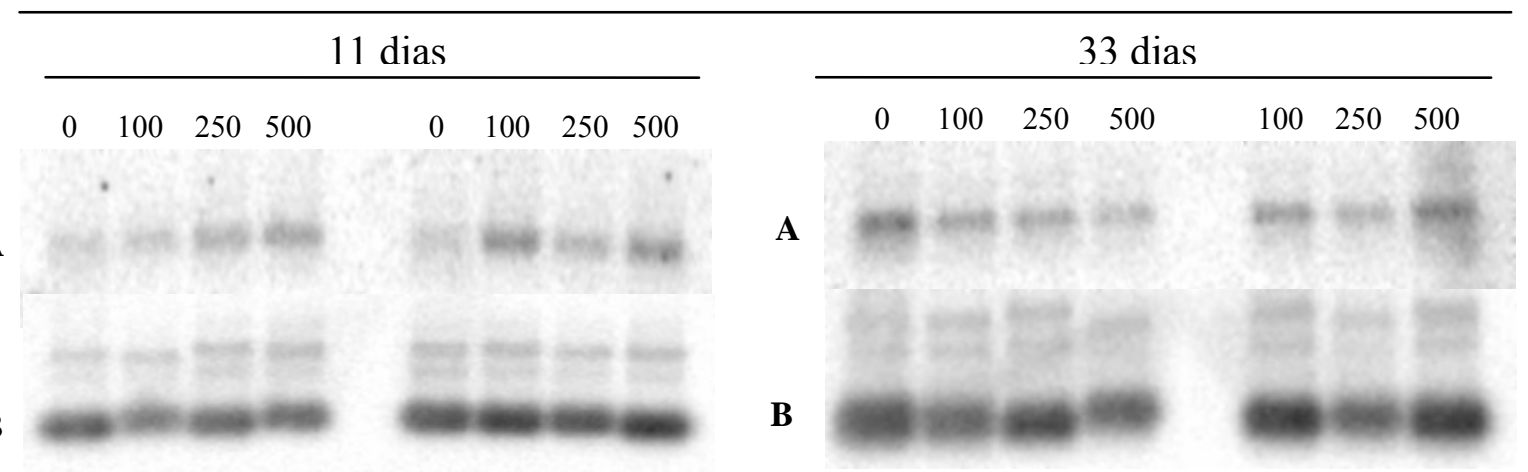

Figura 19 - Northern blot de membranas contendo RNA total extraído de plantas de cana de açúcar após tratamento com doses crescentes de cádmio hibridizadas com sonda de Metalotioneína II (A) ou gene ribossomal (B). Tratamentos com $0 \mu \mathrm{M}$ (controle sem cádmio); $100 \mu \mathrm{M} ; 250 \mu \mathrm{M}$; e 500 $\mu \mathrm{M}$ 
PARTE AÉREA

\begin{tabular}{llllllll}
\hline \multicolumn{10}{c}{11 dias } \\
\hline 0 & 100 & 250 & 500 & 0 & 100 & 250 & 500
\end{tabular}

\begin{tabular}{llllllll}
\hline \multicolumn{10}{c}{33 dias } \\
\hline 0 & 100 & 250 & 500 & 0 & 100 & 250 & 500
\end{tabular}

A

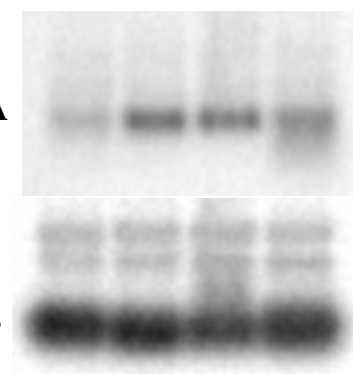

(

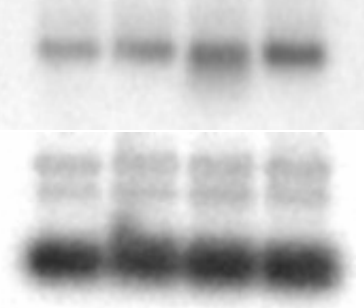

A

\section{RAÍZES}

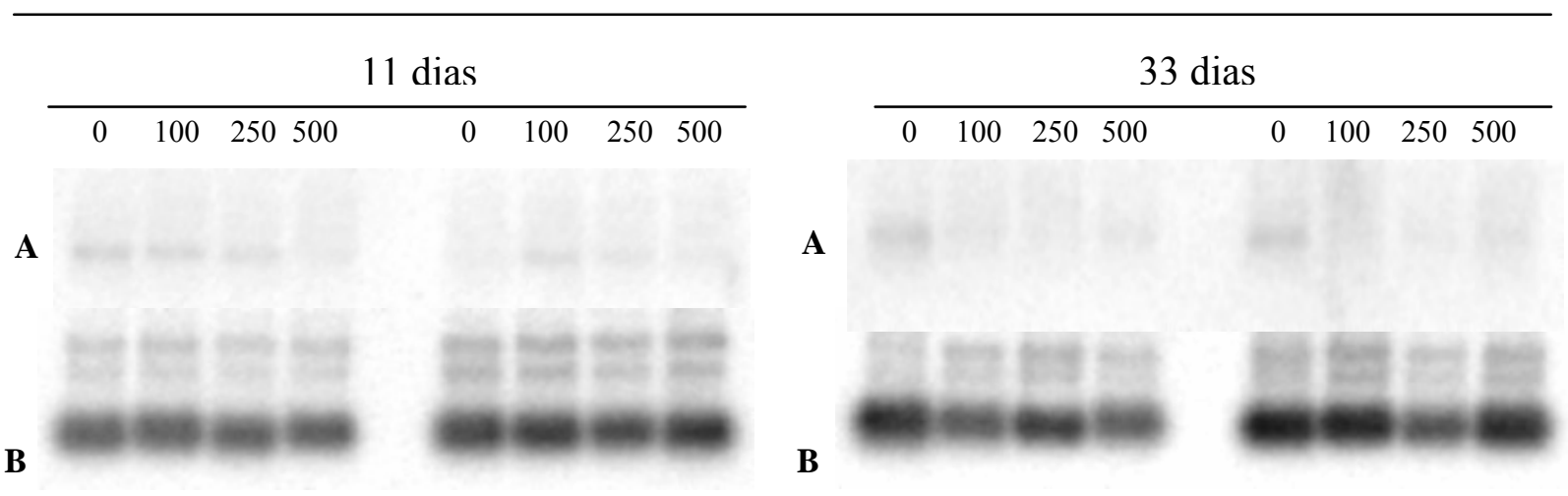

Figura 20 - Northern blot de membranas contendo RNA total extraído de plantas de cana de açúcar após tratamento com doses crescentes de cádmio hibridizadas com sonda de Metalotioneína III (A) ou gene ribossomal (B). Tratamentos com $0 \mu \mathrm{M}$ (controle sem cádmio); $100 \mu \mathrm{M} ; 250 \mu \mathrm{M}$; e $500 \mu \mathrm{M}$ 
Não é possível estabelecer se existe um efeito causal do $\mathrm{Cd}$ na indução das metalotioneínas, ou ela reflete uma resposta ao estresse generalizado causado pelo metal, principalmente porque o efeito mais nítido é nas raízes, que acumulam os maiores teores. Em Cicer arietinum (grão-de-bico) o gene CanMT-1 foi claramente induzido pela presença de cádmio, enquanto que CanMT-2 não parece ser afetado, ou então é levemente reduzido em sua expressão em relação ao controle (Muñoz et al., 1998). De forma similar o gene wali-1 de trigo (MT1) foi altamente expresso em raízes submetidas a dose crescentes de cádmio (Snowden et al., 1995). Alguns dos genes de metalotioneínas são reconhecidamente induzidos como parte de uma resposta geral ao estresse, principalmente oxidativo, apesar de poder existir uma relação indireta com presença de metais (Cobbett \& Goldsbrough, 2002).

Devido as diferenças nas seqüências, especificidade de tecido e respostas aos diferentes estímulos, foi proposto que as diferente isformas de MTs teriam funções diferentes (Cobbet \& Goldsbrough, 2002; Guo et al., 2003). Com relação aos metais foram sugeridas as funções de homeostasia e transporte de micronutrientes e/ou efeito antioxidante. As metalotioneínas oferecem proteção contra os efeitos tóxicos do cádmio em animais, mas nas plantas, essa função foi claramente demonstrada para outro tipo de proteínas quelante de metais, as fitoquelatinas. Por outro lado, as fitoquelatinas não ofereceram tolerância ao cobre em Arabidopsis. Esses dados, embora não conclusivos, apóiam o papel das MTs na tolerância ao cobre (Cobbet \& Goldsbrough, 2002).

Para vários micronutrientes, incluindo o cobre, foi observado que a expressão dos genes de MTs é modulada dependendo da concentração dos íons no meio. O gene htMT2, altamente expressos constitutivamente em nós e internos de $H$. 
tuberosus, foram fortemente reprimidos na presencia de altas dose de cobre e zinco (Chang et al., 2004). Neste caso, foi sugerido que htMT2 poderia estar envolvido no transporte ou disponibilidade de $\mathrm{Cu}$ e $\mathrm{Zn}$ para certas apo-metalo-enzimas ou apo-metaloproteínas envolvidas em processos fisiológicos no caule, especialmente quando as concentrações de $\mathrm{Cu}$ ou $\mathrm{Zn}$ são baixas. Funções relativas ao transporte ou intercambio de cobre já tinham sido propostas para o gene MT1a de Arabidopsis (Garcia-Hernandez et al., 1998) o qual foi altamente expresso em ovário e anteras de flores durante o desenvolvimento, tecidos estes ricos em cobre.

No presente trabalho com cana-de-açúcar ambos metais utilizados tiveram pouco ou nenhum efeito sobre a expressão dos genes MTs. No entanto, o cádmio parece modular essa expressão de forma mais clara que a observada para o cobre. Estudos complementares envolvendo outros metais e outras concentrações seriam de importância para uma interpretação mais sólida do trabalho e dariam uma informação mais completa sobre o efeito dos metais pesados na expressão de metalotioneínas em cana-de-açúcar. 


\section{CONCLUSÕES}

Tendo em vista os resultados aqui apresentados, conclui-se que:

A cana-de-açúcar tem demonstrado possuir tolerância natural a doses elevadas de metais pesados $(\mathrm{Cu}$ e $\mathrm{Cd})$;

$>$ As análises de teor de metais em tecidos de plântulas de cana cultivadas em doses crescentes de $\mathrm{Cu}$ e $\mathrm{Cd}$ demonstraram que ocorre absorção e translocação para parte aérea de quantidades significativas de cobre e cádmio;

As raízes das plântulas cultivadas na presença de metais exibiram concentrações mais elevadas do que a parte aérea;

$>$ Os genes das metalotioneínas I, II e III parecem ser codificados por pequenas famílias gênicas, sendo cada tipo de metalotioneína representada por cerca de 6 a 10 cópias por genoma haplóide; 
$>$ O nível elevado de expressão constitutiva de MT I, seguido de MT II, assim como o perfil espacial de expressão dos genes de MT I, II e III, foi confirmado, e seguem o padrão geral observado em outros sistemas vegetais;

$>$ Não houve indução ou repressão importante na expressão dos genes de metalotioneína I, MT II ou MT III nas condições e concentrações empregadas de cobre;

$>$ Ocorreu um acúmulo de transcritos dos três tipos de MT nas raízes aos 11 dias na presença de $\mathrm{Cd}$, que é seguido de um decréscimo de transcritos aos 33 dias;

$>$ Houve uma indução de MT I e principalmente MT III na parte aérea, com o aumento da concentração de cádmio na solução, mais acentuada aos 11 dias. 


\section{REFERÊNCIAS BIBLIOGRÁFICAS}

ABDULLAH, S.N.A.; CHEAH, S.C.; MURPHY, D.J. Isolation and characterisation of two divergent type 3 metallothioneins from oil palm, Elaeis guineensis. Plant Physiology and Biochemistry, v.40, n.3, p.255-263, 2002.

ALJANABI, S.M., FORGET, L.; DOOKUN, A. An improved and rapid protocol for the isolation of polysaccharide- and polyphenol-free sugarcane DNA. Plant Molecular Biology Reporter, v.17, p1-8, 1999.

BINZ, P.A.; KÄGI, J.H.R. Metallothionein. http://www.unizh.ch/ mtpage/MT.html (21 Jun 2004).

BUCHANAN-WOLLASTON, V.; AINSWORTH, C. Leaf senescence in Brassica napus: cloning of senescence related genes by subtractive hybridization. Plant Molecular Biology, v. 33, p.821-834, 1997.

CHANG, T.J.; LIU, X.; XU, H.L.; MENG, K.; CHEN, S.B.; ZHU, Z. A metallothionein-like gene htMT2 strongly expressed in internodes and nodes of Helianthus tuberosus and effects of metal ion treatment on its expression. Planta, v.218, n.3, p.449-455, 2004. 
CHANEY, R.L.; LI, Y.M.; BROWN, S.L.; HOMER, F.A.; MALIK, M.; ANGLE, J.S.; BAKER, A.J.M.; REEVES, R.D.; CHIN, M. Improving metal hyperaccumulator wild plants develop commercial phytoextraction systems: approaches and progress. In: TERRY, N.; BAÑUELOS, G. (Ed.) Phytoremediation of contaminated soil and water. Florida: CRC Press, 1999. p.129-158.

CHAOUI, A.; GHORBAL, M.H.; EL FERJANI, E. Effects of cadmium-zinc interactions on hydroponically grown bean (Phaseolus vulgaris L.). Plant Science, v.126, p.21-28, 1997.

CHATTHAI, M.; KAUKINEN, K.H.; TRANBARGER T. J.; GUPTA, P.K.; MISRA, S. The isolation of a novel metallothionein-related cDNA expressed in somatic and zygotic embryos of Douglas-fir: regulation by ABA, osmoticum, and metal ions. Plant Molecular Biology, v.34, p.243-254, 1997.

CHEN, L.M.; CHUAN, C.L.; KAO, C.H. Copper toxicity in rice seedlings: Changes in antioxidative enzyme activities, $\mathrm{H}_{2} \mathrm{O}_{2}$ level, and cell wall peroxidase activity in roots. Botanical Bulletin of Academia Sinica, v.41, n.2, p. 99-103, 2000.

CHEN, H.J.; HOU, W.C., YANG, C.Y.; HUANG, D.J.; LIU, J.S.; LIN, Y.H. Molecular cloning of two metallothionein-like protein genes with differential expression patterns from sweet potato (Ipomoea batatas) leaves. Journal of Plant Physiology, v.160, n.5, p.547-555, 2003.

CHOI, D.; KIM, H.M.; YUN, H.K.; PARK, J.A.; KIM, W.T; BOK, S.H. Molecular cloning of a metallothionein-like gene from Nicotiana glutinosa L and its induction by wounding and tobacco mosaic virus infection. Plant Physiology, v.112, n.1, p.353-359, 1996. 
CLENDENNEN, S.K., MAY, G.D. Differential gene expression in ripening banana fruit. Plant Physiology, v.115, n.2, p.463-469, 1997.

COBBETT, C.; GOLDSBROUGH, P. Phytochelatins and Metallothioneins: Roles in Heavy Metal Detoxification and Homeostasis. Annual Review of Plant Biology, v.53, p.159-182, 2002.

COPERSUCAR http://www.copersucar.com.br/2/detalhes variedades.pdf $\quad$ (30 jul. 2004).

COYLE, P.; PHILCOXA, J.C.; CAREYA, L.C.; ROFEA, A.M. Metallothionein: The multipurpose protein Cellular and Molecular Life Sciences, v.59, n.4, p.627-647, 2002.

DAVIES, C.; ROBINSON, S.P. Differential screening indicates a dramatic change in mRNA profiles during grape berry ripening. Cloning and characterization of cDNAs encoding putative cell wall and stress response proteins. Plant Physiology, v.122, n.3, p.803-812, 2000.

de FRAMOND, A.J. A metallothionein-like gene from maize (Zea mays): cloning and characterization. FEBS Letters, v.290, p.103-106, 1991.

DÖNMEZ, G.; AKSU, Z. The effect of copper (II) ions on the growth and bioaccumulation properties of some yeasts. Process Biochemistry, v.35, p.135-142, 1999. 
EVANS, K.M.; GATEHOUSE, L.N.; GATEHOUSE, J.A.; ROBINSON, N.J.; CROY, R.R.D. A gene from pea (Pisum sativum L.) with homology to metallothionein genes. FEBS Letters, v.262, p.29-32, 1990.

EVANS, K.M.; GATEHOUSE, J.A.; LINDSAY, W.P.; SHI, J.; TOMMEY, A.M; ROBINSON, N.J. Expression of the pea metallothionein-like gene PsMTA. Escherichia coli and Arabidopsis thaliana and analysis of trace-metal ion accumulation- implications for PsMTA function. Plant Molecular Biology, v.20, p.1019-1028, 1992.

FIGUEIRA, A.; KIDO, E.A.; ALMEIDA, R.S. Identifying sugarcane expressed sequences associated with nutrient transporters and peptide metal chelators. Genetics and Molecular Biology, v.24 n.1/4, p. 207-220, 2001.

FOLEY RC, SINGH KB. Isolation of a Vicia faba metallothionein-like gene: expression in foliar trichomes. Plant Molecular Biology, v.26, p. 435-44, 1994.

FORDHAM-SKELTON, A.P.; LILLEY, C.; URWIN, P.E.; ROBINSON, N.J. GUS expression in Arabidopsis directed by 5' regions of the pea metallothionein-like gene PsMTA. Plant Molecular Biology, v.34, p.659-668, 1997.

FORDHAM-SKELTON, A.P.; ROBINSON, N.J.; GOLDSBROUGH, P.B. Metallotionein-like genes and phytochelatins in higher plants. In: SILVER, S.; WALDEN,W. (Ed.). Metal ions in gene regulation. London: Chapman and Hall, 1998. p.398-431. 
FORNAZIER, R.F.; FERREIRA, R.R.; VITORIA, A.P.; MOLINA, S.M.G.; LEA, P.J.; AZEVEDO, R.A. Effects of Cadmium on Antioxidant Enzyme Activities in Sugar Cane. Biologia Plantarum, v.45, n.1, p. 91-97, 2002.

FOWLER, B.A.; HIELDEBRAND, C.E.; KOJIMA, Y.; WEBB, M. Nomenclature of metallothionein. In: KAGI, J.H.R.; KOJIMA, Y. (Ed.). Metallothionein II. Basel: Birkhäuser-Verlag, 1987. p.19-22.

FOX, T.C. GUERINOT, M.L. Molecular biology of cation transport in plants. Annual Review of Plant Physiology and Plant Molecular Biology, v.49, p.669-696, 1998.

GADD, G.M. Biosorption. Chemistry and Industry, v.2, p.421-426, 1990.

GADD, G.M.; WHITE, C. Microbial treatment of metal pollution - a working biotechnology. Trends in Biotechnology, v.11, p.353-359, 1993.

GARCIA-HERNANDEZ, M., MURPHY, A.; TAIZ, L. Metallothioneins 1 and 2 have distinct but overlapping expression patterns in Arabidopsis. Plant Physiology, v.118, p.387-397, 1998.

GHOSHROY, S.; FREEDMAN, K.; LARTEY, R.; CITOVSKY, V. Inhibition of plant viral systemic infection by non-toxic concentrations of cadmium. The Plant Journal, v.13, p.591-602, 1998.

GIBBINGS, J.G.; COOK, B.P.; DUFAULT, M.R.; MADDEN, S.L.; KHURI, S.; TURNBULL, C.J.; DUNWELL, J.M. Global transcript analysis of rice leaf and seed using SAGE technology Plant Biotechnology Journal, v.1, n.4, p.271-285, 2003. 
GIMENO-GARCIA, E.; ANDREU, V.; BOLUDA, R. Heavy metals incidence in the application of inorganic fertilizers and pesticides to rice farming soils. Environmental Pollution, v.92, p.19-25, 1996.

GIORDANI, T.; NATALI, L.; MASERTI, B.E.; TADDEI, S.; CAVALLINI, A Characterization and Expression of DNA Sequences Encoding Putative Type-II Metallothioneins in the Seagrass Posidonia oceanica. Plant Physiology, v.123, p.1571-1581, 2000.

GIRITCH, A., GANAL, M., STEPHAN, U.W.; BÄUMLEIN, H. Structure, expression and chromosomal localisation of the metallothionein-like gene family of tomato. Plant Molecular Biology, v.37, p.701-714, 1998.

GOLDSBROUGH, P.B. Metal Tolerance in Plants: the role of phytochelatins and metallothioneins. In: TERRY, N.; BANUELOS, G.S. (Ed). Phytoremediation of contaminated soils and water. Florida: CRC Press, 1999. p.221-233.

GRIVET, L.; GLASZMANN, J.C.; VINCENTZ, M.; DA SILVA, F.; ARRUDA, P. ESTs as a source for sequence polymorphism discovery in sugarcane: example of the Adh genes. Theorical Applied Genetics, v.106, p.190-197, 2003.

GUO, W.J.; BUNDITHYA, W.; GOLDSBROUGH, P. B. Characterization of the Arabidopsis metallothionein gene family: tissue-specific expression and induction during senescence and in response to copper. New Phytologist, v.159, p.369-381, 2003. 
HIGHAM, D.P.; SADLER, P.J.; SCAWEN, M.D. Cadmium resistant Pseudomonas putida synthesize novel cadmium proteins. Science, v.225, p.1043-1045, 1984.

HSIEH, H.M.; LIU, W.K.; HUANG, P.C. A novel stress-inducible metallothionein-like gene from rice. Plant Molecular Biology, v. 28, n.3, p.381-389, 1995.

HOAGLAND, D.R.; ARNON, D.I. The water culture method for growing plants without soil. Berkeley: University of California, California Agriculture Experimental Station, 1953. (Circular 347).

HUANG, Y.J.; TO, K.Y.; YAP, M.N.; CHIANG, W.J.; SUEN, D.F.; CHEN, S.C.G. Cloning and characterization of leaf senescence up-regulated genes in sweet potato. Physiologia Plantarum, v.113, n.3, p.384-391, 2001.

HUDSPETH, R.L.; HOBBS, S.L.; ANDERSON, D.M.; RAJASEKARAN, K.; GRULA, J.W. Characterization and expression of metallothionein-like genes in cotton. Plant Molecular Biology, v.31, p. 701-705, 1996.

JORDÃO, C.P.; DA SILVA, A.C.; PEREIRA, J.L.; BRUNE, W. Contaminação por crômio de rios provenientes de curtumes em Minas Gerais. Química Nova, v.22, p.47-52, 1999.

KAGI, J.H.R. Overview of metallothionein. Methods in Enzymology, v.205, p.613$626,1991$.

KAPOOR, A.; VIRARAGHAVAN, T.; CULLIMORE, D.R. Removal of heavy metals using the fungus Aspergillus nidulans. Bioresource Technology, v.70, p.95-104, 1999. 
KAWASHIMA, I.; INOKUCHI, Y.; CHINO, M.; KIMURA, M.; SHIMIZU, N. Isolation of a gene for a metallothionein-like protein from soybean. Plant Cell Physiology, v.32, p.913-916, 1991.

KEFALA, M.I.; ZOUBOULIS, A.I.; MATIS, K.A. Biosorption of cadmium ions by Actinomycetes and separation by flotation. Environmental Pollution, v.104, p.283293, 1999.

KIM, S.; AHN, I.P.; LEE, Y.H. Analysis of genes expressed during rice - Magnaporthe grisea interactions. Molecular Plant-Microbe Interactions, v.14, p.1340-1346, 2001 .

KOJIMA Y.; BINZ P.A.; KAGI J.H.R. Nomenclature of metallothionein: proposal for a revision. In: KLAASSEN C. (Ed.). Metallothionein IV. Basel: BirkhäuserVerlag, 1999. p.3-6.

LANE, B.; KAJIOKA, R.; KENNEDY, T. The wheat germ Ec protein is a zinccontaining metallothionein. Biochemistry and Cell Biology, v.65, p.1001-1005, 1987.

LAPLAZE, L.; GHERBI, H.; DUHOUX, E.; PAWLOWSKI, K.; AUGUY, F.; GUERMACHE, F.; FRANCHE, C.; BOGUSZ, D. Symbiotic and non-symbiotic expression of $\operatorname{cgMT} 1$, a metallothionein-like gene from the actinorhizal tree Casuarina glauca. Plant Molecular Biology, v.49, n.1, p.81-92, 2002.

LEDGER, S.E.; GARDNER, R.C. cloning and characterization of 5 cDNAs for genes differentially expressed during fruit-development of kiwi-fruit (Actinidia-deliciosa var deliciosa). Plant Molecular Biology, v.25, n.5, p.877-886, 1994. 
LOU, L.Q.; SHEN, Z.G.; LI, X.D. The copper tolerance mechanisms of Elsholtzia haichowensis, a plant from copper-enriched soils. Environmental and Experimental Botany, v.51, n.2, p. 111-120, 2004.

MA, M.; LAU, P.S.; JIA, Y.T.; TSANG, W.K.; LAM, S.K.S.; TAM, N.F.Y.; WONG, Y.S. The isolation and characterization of Type 1 metallothionein (MT) cDNA from a heavy-metal-tolerant plant, Festuca rubra cv. Merlin. Plant Science, v.164, n.1, p.51-60, 2003.

MACLEAN, F.I.; LUCIS, O.J.; SHAKH, Z.A.; JANSZ, E.R. The uptake and subcellular distribution of $\mathrm{Cd}$ and $\mathrm{Zn}$ in microorganisms. Federation Proceedings, v.31, n.2, p.A699-\&, 1972.

MALAVOLTA, E. Fertilizantes e seu impacto ambiental: micronutrientes e metais pesados, mitos, mistificação e fatos. São Paulo: Produquímica, 1994. 153p.

MARGOSHES, M.; VALLEE, B.L. A cadmium protein from equine kidney cortex. Journal of American Chemical Society, v.79, p.4813-4814, 1957.

MATSUMURA, H.; NIRASAWA, S.; TERAUCHI, R. Transcript profiling in rice (Oryza sativa L.) seedlings using serial analysis of gene expression (SAGE). Plant Journal, v.20, p.719-726, 1999.

MOROZZI, G.; DI MARCO, L.; CONTENTI, S.; MANGIABENE, C.; SCARDAZZA, F. The presence of high-molecular weight proteins with a strong affinity for cadmium in environmental Escherichia coli strains. Microbios, v.75, p.7-16, 1993. 
MUNGER, K.; GERMANN, U.A.; LERCH, K. The Neurospora crassa metallothionein gene. Journal of Biological Chemistry, v.262, p.7363-7367, 1987.

MUÑOZ, F.J.; ULLAN, R.V.; LABRADOR, E.; DOPICO, B. Increased expression of two cDNAs encoding metallothionein-like proteins during growth of Cicer arietinum epicotyls. Physiologia Plantarum, v.104, n.2, p.273-279, 1998.

MURPHY, A.S.; TAIZ, L. Comparison of metallothionein gene expression and nonprotein thiols in ten Arabidopsis ecotype. Plant Physiology, v.109, p.945-954, 1995.

MURPHY, A.S.; ZHOU, J., GOLDSBROUGH P.B.; TAIZ. L. Purification and immunological identification of metallothioneins 1 and 2 from Arabidospsis thaliana. Plant Physiology, v.113, p.1293-1301, 1997.

NORDBERG, M.; KOJIMA, Y. Metallothionein and other low molecular weight metalbinding proteins. In: KAGI, J.H.R. AND NORDBERG, M. (Ed). Metallothionein. Basel: Brikhäuser-Verlag, 1979. p. 41-124.

OLIVEIRA, J.P.; SIQUEIRA, M.E.P.B.; SILVA, C.S. Urinary nickel as bioindicator of workers' Ni exposure in a galvanizing plant in Brazil. International Archives of Occupational and Environmental Health, v.73, n.1, p. 65-68, 2002.

OUZOUNIDOU, G.; CIAMPOROVA, M.; MOUSTAKAS, M.; KARATAGLIS, S. Responses of maize (Zea-mays L) plants to copper stress 1.: Growth, mineral content and ultrastructure of roots. Environmental and Experimental Botany, v.35, n.2, p.167-176, 1995. 
RAUSER, W. E. Structure and function of metal chelators produced by plants: the case for organic acids, amino acids, phytin and metallothioneins. Cell Biochemistry and Biophysics, v.31, p.19-48, 1999.

REEVES, R.D.; BAKER; A.J.M.; BROOKS, R.R. Abnormal accumulations of trace metals by plants. Mining Environmental Management, v.9, p.4-8, 1995.

REID, S.J.; ROSS, G.S. Up-regulation of two cDNA clones encoding metallothioneinlike proteins in apple fruit during cool storage. Physiologia Plantarum, v.100, n.1, p.183-189, 1997.

ROBINSON, N.J.; GUPTA, A.; FORDHAM-SKELTON, A.P.; CROY, R.D.R.; WHITTON, B.A.; HUCKLE, J.W. Prokaryotic metallothionein gene characterization and expression: chromosome crawling by ligation-mediated PCR. Proceedings of Royal Society, v.242, p.241-247, 1990.

ROBINSON, N.J.; TOMMEY, A.T.; KUSKE, C.; JACKSON, P.J. Plant metallothioneins. Biochemistry. Journal, v.295, p.1-10, 1993.

ROMANTSCHUK, M.; SARAND, T.; PETÄNEN, R.; PELTOLA, R.; JONSSONVIHANNE, M.; KOIVULA, T.; YRJÄLÄ, K.; HAAHTELA, K. Means to improve the effect of in situ bioremediation of contaminated soil: an overview of novel approaches. Environmental Pollution, v.107, p179-185, 2000.

SALT, D.E.; SMITH, R.D.; RASKIN, I. Phytoremediation. Annual Review of Plant Physiology. Plant Molecular Biology, v.49, p.643-668, 1998. 
SCANDAliOS, J.G. Oxygen stress and superoxide dismutases. Plant Physiology, v.101, p.7-12, 1993.

SCHICKLER, H.; CASPI, H. Response of antioxidative enzymes to nickel and cadmium stress in hyperaccumulator plants of the genus Alyssum. Physiologia Plantarum, v.105, p.39-44, 1999.

SHU, W.S.; YE, Z.H.; LAN, C.Y.; ZHANG, Z.Q.; WONG, M.H. Lead, zinc and copper accumulation and tolerance in populations of Paspalum distichum and Cynodon dactylon. Environmental Pollution, v.120, n.2, p.445-453, 2002.

SINGH, O.V.; LABANA, S.; PANDEY, G.; BUDHIRAJA, R.; JAIN, R.K. Phytoremediation of toxic aromatic pollutants from soil. Applied Microbiology and Biotechnology, v.63, n.2, p.128-135, 2003.

SNOWDEN, K.C.; GARDNER, R.C. 5 genes induced by aluminum in wheat (Triticumaestivum L) roots. Plant Physiology, v.103, n.3, p.855-861,1993.

SNOWDEN, K.C.; RICHARDS, K.D.; GARDNER, R.C. Aluminum-induced genes induction by toxic metals; low-calcium; and wounding and pattern of expression in root-tips. Plant Physiology, v.107, n.2, p.341-348, 1995.

SUCEST: SUGAR CANE EST PROJECT, http://sucest.lad.dcc.unicamp.br/en/ (20 mai. 2002).

VEGLIO, F.; BEOLCHINI, F. Removal of metals by biosorption: a review. Hydrometallurgy, v.44, p.301-316, 1997. 
WAIHUNG, L.; CHUA, H.; LAM, K.H.; BI, S.P. A comparative investigation on the biosorption of lead by filamentous fungal biomass. Chemosphere, v.39, p.2723$2736,1999$.

YANG, X.E.; BALIGAR, V.C.; MARTENS, D.C.; CLARK R.B. Infux, transport, and accumulation of cadmium in plant species grown at different $\mathrm{Cd} 2+$ activities. Environmental Science \& Health, v.B30, p.569-583, 1995.

YANG, X.E.; LONG, X.X.; YE, H.B.; HE, Z.L.; CALVERT, D.V.; STOFFELLA, P.J. Cadmium tolerance and hyperaccumulation in a new Zn-hyperaccumulating plant species (Sedum alfredii Hance). Plant and Soil, v. 259, n1/2, p.181-189, 2004.

ZHANG, Y.W.; TAM, N.F.Y.; WONG, Y.S. Cloning and characterization of type 2 metallothionein-like gene from a wetland plant, Typha latifolia. Plant Science, v.167, n.4, p.869-877, 2004.

ZHOU, J.; GOLDSBROUGH P.B. Functional homologs of fungal metallothionein genes from Arabidopsis. Plant Cell, v.6, p.875-884, 1994.

ZHOU, J.; GOLDSBROUGH, P.B. Structure, organization and expression of the metallothionein gene family in Arabidopsis. Molecular and General Genetics, v.248, p.318-328, 1995. 